\title{
Z DOROBKU POLSKIEJ LEKSYKOGRAFII DZIEDZINOWEJ: BOTANIKA
}

\author{
KATARZYNA WOJAN \\ Uniwersytet Gdański \\ Wydział Filologiczny \\ Instytut Skandynawistyki \\ Pracownia Języka Fińskiego, Kultury i Gospodarki Finlandii \\ Neofilologia, ul. Wita Stwosza 51, 80-308 Gdańsk, Polska \\ e-mail: finkw@univ.gda.pl \\ (nadesłano 6.08.2017; zaakceptowano 21.10.2017)
}

\section{Abstract \\ On the achievements of Polish specialised lexicography: botany}

The article documents the achievements of Polish lexicographers (terminologists, encyclopaedists, ethnobotanists, herbalists) in botany. It contains a comprehensive list of 831 lexicographic works published in Poland in the years 1472-2017, including terminology dictionaries, encyclopaedias, indexes, glossaries, botanical atlases, alphabetical compendia, guides, etc. The bibliography is comprehensive and annotated.

The bibliographical material was extracted from library catalogues of various academic institutions and scientific centres in Poland, catalogues of publications, as well as from scientific works (monographs, articles) in the field of phytology and ethnobotany.

\section{Key words}

Polish lexicography, terminography, botanical dictionaries, encyclopaedic dictionaries, science, bibliography of dictionaries, phytology, herbarium. 


\section{Abstrakt}

Artykuł dokumentuje dorobek polskich leksykografów (terminologów, encyklopedystów, etnobotaników, zielnikoznawców i in.) w dziedzinie botaniki. Zamieszczono obszerny wykaz 831 opracowań leksykograficznych, wydanych w Polsce w latach 1472-2017. Do opracowań słownikarskich zaliczono teksty różnego gatunku, takie jak słowniki terminologiczne, encyklopedyczne, spisy, indeksy, glosariusze, atlasy botaniczne, ułożone alfabetycznie kompendia, przewodniki itd. Bibliografia ma charakter kompleksowy i adnotowany.

Materiał do bibliografii wyekscerpowany został z rozproszonych katalogów bibliotecznych instytucji naukowych i ośrodków naukowo-dydaktycznych w Polsce, katalogów wydawniczych, a także z prac naukowych (monografii, artykułów) z zakresu fitonimiki i etnobotaniki.

\section{Słowa kluczowe}

Polska leksykografia dziedzinowa, terminografia, słowniki botaniczne, słowniki encyklopedyczne, naukoznawstwo, bibliografia słowników, fitonimika, zielniki.

Mają oddawna Indjanie, Persowie, Turcy i inne narody Wschodu właściwe sposoby wyrażenia myśli swych przez rozmaite kwiatów składanie... Karol Ferdynand Ney ${ }^{1}$

\section{O polskiej leksykografii botanicznej}

Piśmiennictwo polskie na temat onomastyki botanicznej jest nader obszerne ${ }^{2}$; jego poszczególne działy omawiały Halina Chodurska ${ }^{3}$, Ewa Rogowska-Cybulska ${ }^{4}, K$ rystyna Szcześniak ${ }^{5}$, Jadwiga Waniakowa ${ }^{6}$ i in. Rzadziej natomiast koncentruje się ono na prezentacji całościowego dorobku leksykografów polskich. Autorzy prac naukowych korzystają, rzecz jasna, obficie z rozmaitych typów opracowań leksykograficznych

\footnotetext{
1 Mańkowski A. ks. Karol Ferdynand Ney. „Zapiski Towarzystwa Naukowego w Toruniu” 1925, t. VI, nr 11, s. 156.

2 Por. J. Waniakowa. Polskie gwarowe nazwy dziko rosnących roślin zielnych na tle słowiańskim. Zagadnienia ogólne. Kraków: Wydawnictwo Uniwersytetu Jagiellońskiego, 2012, s. 14.

3 Zob. m.in. J. Chodurska. Ze studiów nad fitonimami rękopiśmiennych zielników wschodniosłowiańskich XVII-XVIII wieku. Seria Prace Monograficzne. Akademia Pedagogiczna im. Komisji Edukacji Narodowej w Krakowie, nr 360. Kraków: Wydawnictwo Naukowe Akademii Pedagogicznej, 2003.

4 Zob. m.in. E. Rogowska. Kaszubskie nazwy roślin uprawnych. Gdańsk: Wydawnictwo Uniwersytetu Gdańskiego, 1998.

5 Zob. m.in. K. Szcześniak. Świat roślin światem ludzi na pograniczu wschodniej i zachodniej Słowiańszczyzny. Gdańsk: Wydawnictwo Uniwersytetu Gdańskiego, 2008 (wyd. 2 popr. - Gdańsk 2013). 6 Zob. m.in. J. Waniakowa. Polskie gwarowe nazwy dziko rosnących roślin zielnych na tle słowiańskim...
} 
dotyczących świata roślin, przede wszystkim z encyklopedii, przewodników, atlasów, kluczy do oznaczania, spisów, indeksów, nomenklatorów itd., zaś podstawę siatek hasłowych słowników roślin stanowiły w przeszłości i nadal stanowią zielniki ${ }^{7}$ (herbaria) ${ }^{8}$. W nauce polskiej dokonano m.in. podsumowań osiągnięć w zakresie leksykografii rolniczej, i to na tle porównawczym z dorobkiem innych krajów (prace Lesława Zimnego ${ }^{9}$ ). Jednak jak dotąd, nie wydano monografii poświęconej polskiemu słownikarstwu fitonimicznemu. Nie ma też kompleksowego opracowania bibliograficznego w zakresie polskiej terminografii botanicznej ani encyklopedystyki.

W celu przybliżenia - jakże bogatego - polskiego dorobku leksykograficznego sporządzono zatem niniejszy wykaz 831 pozycji różnego typu (gatunku), wydanych na Ziemiach Polskich w latach 1472-2017, bądź (sporadycznie) przez polskich autorów za granicą. Opracowania leksykograficzne ułożono w porządku chronologicznym. Załączona do nich bibliografia może posłużyć jako obiektywne narzędzie do wieloaspektowego opisu dokonań naszych rodaków i oceny ich wkładu do naukoznawstwa.

Najstarszą (rękopiśmienną) pracą jest Antibolomenum (Antidotarium, Antibolarium) Benedicti Parth $i^{10}$ Jana Stanko z 1472 roku, będące nie tylko potężną encyklopedią fitonimiczną, ale również niezwykle wartościowym kompendium medyczno-farmaceutycznym. W dziele tym odnotowano nazwy 90 gatunków roślin zagranicznych i 433 gatunków krajowych ${ }^{11}$. Z kolei pierwszym polskim zielnikiem jest renesansowy Hortus sanitatis. O ziołach i o mocy ich (O paleniu wodek z ziol; O Oleykoch przyprawianiu; O Rzeczach zamorskich; O Zwierzętach, o Ptaszech, y o Ribach; O Kamieniu drogim; O Urinie, o Pulsie; Y o inych znamionach; O Rodzeniu dziatek; O Naucze gwiazdeczney; O stawianiu baniek; Y o puszczaniu krwie; O Rządzeniu czasu powietrza morowego; O lekarstwiech doswiadczonych na wiele niemoczy; O Naucze Barwierzkiey) Stefana Falimirza (Falimierza) (Cracoviae 1534) ${ }^{12}$, pochodzącego z Rusi botanika

7 Zob. np. J. Chodurska. Nazwy roślin w rosyjskim tłumaczeniu „Zielnika” Szymona Syreniusza. [W:] W świecie Stowian. Szkice z dziejów leksykologii i leksykografii. Red. nauk. H. Chodurska, A. Mażulis-Frydel, A. Radzik. Kraków: Oficyna Wydawnicza Impuls, 2013, s. 47-64.

8 Herbarz to rodzaj popularnej encyklopedii medycznej, której główną część stanowią opisy surowców leczniczych pochodzenia roślinnego, a także zwierzęcego i mineralnego; znajdują się w nim m.in. rozdziały poświęcone sposobom wykonania leków, oznakom chorób, leczeniu przez purgację i upuszczanie krwi, „sprawom brzemiennym” i „rozmaitym niemocam dziecinnym”. Zob. Z. Bela. Etymologia i pierwotne znaczenia wyrazów «lek» $i$ «leczyć». „Gazeta Farmaceutyczna”, marzec 2011, s. 28.

9 Zob. L. Zimny. Leksykografia rolnicza. „Fragmenta Agronomica” 2008, nr 4. [Online:] <http:// karnet.up.wroc.pl/ Zimny/leksykografia.html> (dostęp: 6.08.2017).

10 Rękopis przechowywany jest w Bibliotece Krakowskiej Kapituły Katedralnej, nr Ms 225 (za J. Waniakowa. Osobliwe procesy fonetyczne $w$ gwarowych wyrazach zapożyczonych na przykładzie nazw roślin. [W:] Jazykovedné štúdie XXXII. Prirodzený vývin jazyka a jazykové kontakty. Ed. K. Balleková, G. Múcsková, L. Králik. Bratislava: Veda 2015, s. 209).

11 O tym M. Karnecka. Słownik Jana Stanki - najbogatszy zabytek przyrodniczy średniowiecza. „Rozprawy Komisji Językowej Wrocławskiego Towarzystwa Naukowego" 1976, t. 10, Wrocław, s. 119-155. 12 Digitalizacja dzieła w Cyfrowej Bibliotece Narodowej Polona: <https://polona.pl/ item/o-ziolach-y-o-moczy-gich-o-paleniu-wodek-z-ziol-o-oleykach-przyprawianiu-orzeczach,MzMzMDIwNw/5/\#item>. 
i lekarza, który rozwijał polską terminologię medyczną ${ }^{13}$. Ów zielnik był parokrotnie wznawiany.

Do ciekawych archiwaliów należy broszurka Kwiaty czyli Wykład znaczeń blisko tysiąca roślin krajowych i zagranicznych $w$ języku polskim, łacińskim i niemieckim spisanych ułożona przez torunianina, pedagoga, literata i historyka, Karola Ferdynanda Neya „ku użytkowi i zabawie płci obojej” i wydana w Poznaniu w 1841 roku (kolejne wydanie pośmiertne - leszczyńskie).

W 1542 roku Hieronim (Jarosz) Spiczyński (Hieronim z Wielunia), rajca krakowski, lekarz króla Zygmunta Augusta, botanik, pisarz i wydawca, ogłosił drukiem O Ziolach tutecznych y zamorskich y o mocy ich, a kthemu kxiegi lekarskie wedle regestru niżey nowo wypisanego wssem wielmi vzyteczne. Praca została zaopatrzona w Regestr o ziołach - słowniczek polsko-łaciński.

Do ważnych osiągnięć polskiego ziołopisarstwa należy Herbarz Polski to jest o przyrodzeniu ziót i drzew rozmaitych i inszych rzeczy do lekarstw należacych ksiegi dwoje autorstwa Marcina z Urzędowa, powstały w latach 1543-1553, a wydany pośmiertnie w 1595 roku w Krakowie. Jest to ilustrowana encyklopedia z dziedziny botaniki i medycyny, podający wiadomości na temat wystepujących na obszarze Polski roślin, zwierząt i minerałów.

Anton Schneeberger (Schneberger), urodzony w Zurychu lekarz, przyrodnik i humanista, wkrótce po przybyciu do Polski podjął badania nad polską florą. Już w 1556 roku ogłosił drukiem w oficynie Łazarza Andrysowica Medicamentorum simplicium corpus humanum a pestilentiae contagione praeservantium catalogus..., zestawienie różnorodnych leków ze wskazaniem ich stosowania, przy czym do łacińskich nazw ziół dodał odpowiedniki polskie, nie zawsze radząc sobie z ich poprawnością językową. Rezultatem prowadzonych badań florystycznych, głównie $\mathrm{z}$ okolic Krakowa (ale też Rusi i Litwy), był Catalogus stirpium quarundam Latine et Polonice conscriptus..., wydany w 1557 roku również u Andrysowica. Wędrując w poszukiwaniu rzadkich okazów roślin „po lasach, pagórkach, łąkach i mokradłach”, poznał i opisał 432 gatunki roślin (w tym 270 rosnących dziko), których łacińskie nazwy zaczerpnął z pism starożytnych i współczesnych sobie przyrodników (przede wszystkim Gesnera, którego czterojęzyczny Catalogus plantarum z 1542 roku posłużył mu za wzór), zaś odpowiedniki polskie z dzieł Macieja Miechowity, Szymona z Łowicza i Hieronima Spiczyńskiego ${ }^{14}$. Mimo dość słabej kompetencji języka polskiego korzystał też z własnych wywiadów i informacji uzyskiwanych od wiejskich kobiet. Catalogus stirpium był, jak

13 Zob. L.A. Jankowiak. Słownictwo medyczne Stefana Falimirza. T. 1: Początki polskiej renesansowej terminologii medycznej. Instytut Slawistyki Polskiej Akademii Nauk. Towarzystwo Naukowe Warszawskie. Seria Język na Pograniczach, 27. Warszawa: Slawistyczny Ośrodek Wydawniczy, 2005; L.A. Jankowiak. Słownictwo medyczne Stefana Falimirza. T. 2: Słownik. Instytut Slawistyki Polskiej Akademii Nauk. Towarzystwo Naukowe Warszawskie. Seria Język na Pograniczach, 31. Warszawa: Slawistyczny Ośrodek Wydawniczy, 2006.

14 Zob. Anton Schneeberger. [W:] Internetowy polski słownik biograficzny. [Online:] <http://www. ipsb.nina.gov.pl/a/biografia/anton-schneeberger> (dostęp: 1.06.2017). 
podkreślał m.in. Marcin Siennik, pierwszym w piśmiennictwie naszym polsko-łacińskim słownikiem florystycznym ${ }^{15}$.

W 1568 w Krakowie roku światło dzienne ujrzał Herbarz to iest, Zioł tutecznych, postronnych, y Zamorskich opisanie. Co za moc maia, a iako ich uzywać, tak ku przestrzeżeniu zdrowia ludzkiego, iako ku vzdrovienia rozmaitych chorob. Teraz nowo, wedle Herbarzow dzisieyszego wieku, y inych zacnych Medykow, poprawiony Marcina Siennika (Heuwrechera, Pelczmana), wydawcy polskich druków przyrodniczych, botanika, twórcy ponad 800 polskich nazw roślin.

Klasycznym renesansowym dziełem jest ilustrowany Zielnik Herbarzem z ięzyka Łacinskiego zowia To iest Opisanie własne imion, ksztattu, przyrodzenia, skutkow, y mocy Zioł wszelakich Drzew Krzewin y korzenia ich, Kwiatu, Owocow, Sokow Miasg, Zywic y korzenia do potraw zaprawowania Takze Trunkow, Syropow, Wodek Lekiwarzow, Konfektow [...] pilnie zebrane a porzadnie zapisane przez D. Simona Syrennivsa w Krakowie w 1613 roku. Szymon Syreński (Syreniusz, Syrenius, Sacranus) był profesorem Akademii Krakowskiej, lekarzem, botanikiem, badaczem właściwości leczniczych ziół.

W latach 1777-1779 ksiądz katolicki i przyrodnik, Jan Krzysztof Kluk i napisał i wydał w Warszawie pomnikowe trzytomowe dzieło Roslin Potrzebnych, Pozytecznych, Wygodnych, Osobliwie Kraiowych, Albo Ktore W Kraiu Uzyteczne Byc Moga, Utrzymanie, Rozmnozenie I Zazycie (t. 1: O Drzewach, Ziołach Ogrodowych i Ogrodach z Figurami; O Drzewach, Ziołach Ogrodowych i Ogrodach; t. 2: O Drzewach I Ziołach Dzikich, Lasach etc.; t. 3: O Rolnictwie, Zbozach, Łakach, Chmielnikach, Winnicach y Roslinach Gospodarskich). Wkrótce też Kluk opublikował w latach 1786-1788 bezcenny trzytomowy Dykcyonarz Roślinny W Którym Podług Układu Linneusza Sa Opisane Rosliny Nietylko Kraiowe Dzikie, Pozyteczne, Albo Szkodliwe Na Roli, W Ogrodach, Oranzeryach Utrzymywane Ale Oraz Y Cudzoziemskie, Ktoreby W Kraiu Pożyteczne Byc Mogly Albo Z Ktorych Mamy Lekarstwa, Korzenie, Farby, \&c. Albo Ktore Jakowa Nadzwyczaynosc W Sobie Maia Ich Zdatnosci Lekarskie, Ekonomiczne, Dla Ludzi, Koni, Bydła, Owiec, Pszczoł, \&c. Utrzymywanie, \&c. Z poprzedzaiacym wykładem słow Botanicznych y kilkorakim na końcu Regestrem.

Wyraźne zainteresowanie terminologią botaniczną nastąpiło dopiero w XIX wieku. Powstało wówczas 59 opracowań leksykograficznych (tj. 7\% wszystkich zamieszczonych w wykazie). Wraz z rozwojem nauki opracowywano bardziej zróżnicowane kompendia, przewodniki, spisy, katalogi, encyklopedie, słowniki, dopracowywano i aktualizowano wcześniejsze. Wynikiem dokonań uczonych minionego stulecia jest 421 prac słownikowych (tj. 50,66\%). Tylko w latach 90. światło dzienne ujrzało 136 prac (tj. 16,36\% wszystkich). Nowe stulecie (a ściślej: jego niespełna dwie dekady) przyniosło już 333 pozycje bibliograficzne (tj. 40\%).

Język rosyjski uwzględnia zaledwie 26 (tj. 3,12\%) prac słownikarskich; przy czym są to $\mathrm{z}$ reguły prace wielojęzyczne.

Poniższe tabele ilustrują osiągnięcia polskich uczonych w zakresie szeroko pojmowanej terminografii i encyklopedystyki botanicznej oraz zielnikoznawstwa. Tabela pierwsza przedstawia dane dotyczące liczby opracowań leksykograficznych z zakresu

15 Ibidem. 
botaniki w poszczególnych dziesięcioleciach, natomiast tabela druga ilustruje proporcje powstawania i publikowania prac na przestrzeni siedmiu wieków.

Tabela 1. Liczba opracowań leksykograficznych z zakresu botaniki w poszczególnych dziesięcioleciach.

\begin{tabular}{|c|c|c|c|}
\hline lp. & lata & liczba pozycji & udział \% \\
\hline 1. & 1472 & 1 & $0,12 \%$ \\
\hline 2. & 1534 & 1 & $0,12 \%$ \\
\hline 3. & 1542 & 1 & $0,12 \%$ \\
\hline 4. & $1556-1568$ & 4 & $0,48 \%$ \\
\hline 5. & 1595 & 1 & $0,12 \%$ \\
\hline 6. & 1613 & 1 & $0,12 \%$ \\
\hline 7. & $1777-1779$ & 4 & $0,48 \%$ \\
\hline 8. & $1781-1788$ & 5 & $0,60 \%$ \\
\hline 9. & $1802-1808$ & 10 & $1,20 \%$ \\
\hline 10. & 1811 & 1 & $0,12 \%$ \\
\hline 11. & $1824-1829$ & 7 & $0,84 \%$ \\
\hline 12. & $1830-1838$ & 3 & $0,36 \%$ \\
\hline 13. & $1841-1849$ & 7 & $0,84 \%$ \\
\hline 14. & $1851-1859$ & 4 & $0,48 \%$ \\
\hline 15. & $1860-1863$ & 3 & $0,36 \%$ \\
\hline 16. & 1871 & 1 & $0,12 \%$ \\
\hline 17. & $1880-1889$ & 12 & $1,44 \%$ \\
\hline 18 & $1892-1898$ & 11 & $1,32 \%$ \\
\hline 19. & 1900-1906 & 12 & $1,44 \%$ \\
\hline 20. & $1911-1914$ & 4 & $0,48 \%$ \\
\hline 21. & $1921-1929$ & 20 & $2,40 \%$ \\
\hline 22. & 1930-1939 & 36 & $4,33 \%$ \\
\hline 23. & 1946-1948 & 6 & $0,72 \%$ \\
\hline 24. & 1950-1959 & 26 & $3,12 \%$ \\
\hline 25. & 1960-1969 & 52 & $6,25 \%$ \\
\hline 26. & 1970-1979 & 66 & $7,94 \%$ \\
\hline 27. & 1980-1989 & 63 & $7,58 \%$ \\
\hline 28. & 1990-1999 & 136 & $16,36 \%$ \\
\hline 29. & 2000-2009 & 215 & $25,87 \%$ \\
\hline 30. & 2010-2017 & 118 & $14,19 \%$ \\
\hline Łącznie & $1472-2017$ & 831 & $100 \%$ \\
\hline
\end{tabular}

Źródło: opracowanie własne. 
Tabela 2. Liczba opracowań leksykograficznych z zakresu botaniki w poszczególnych stuleciach.

$\begin{array}{lccc}\text { lp. } & \text { stulecie } & \text { liczba pozycji } & \text { udzial \% } \\ 1 . & \text { XV } & 1 & 0,12 \% \\ 2 . & \text { XVI } & 7 & 0,84 \% \\ 3 . & \text { XVII } & 1 & 0,12 \% \\ 4 . & \text { XVIII } & 9 & 1,08 \% \\ 5 . & \text { XIX } & 59 & 7,09 \% \\ 6 . & \text { XX } & 421 & 50,66 \% \\ 7 . & \text { XXI } & 333 & 40,07 \% \\ \text { Lącznie } & \text { XV-XXI } & \mathbf{8 3 1} & \mathbf{1 0 0} \%\end{array}$

Źródło: opracowanie własne.

\section{Podstawa katalogowania}

Materiał faktograficzny wyekscerpowany został z wszelkich dostępnych źródeł bibliograficznych, publikacji naukowych (monografii, artykułów naukowych, recenzji etc.), katalogów bibliotecznych (NUKAT, WorldCat, Biblioteki Narodowej i in.) oraz wydawniczych. Poddano go starannej selekcji dziedzinowej i systematyzacji chronologicznej.

Podczas przygotowywania niniejszej bibliografii do publikacji kierowano się pewnymi zasadami. W procesie konfigurowania wykazu zachowano porządek chronologiczny, co oznacza, iż pozycje słownikarskie pogrupowano według roku ich wydania. W poszczególnych odcinkach czasowych publikacje uszeregowano alfabetycznie według nazwisk autorów, zaś w przypadku opracowań zbiorowych według tytułów - w obu przypadkach zgodnie z kolejnością liter alfabetu polskiego. Nazwiska redaktorów, jak również osób uczestniczących w procesie opracowywania haseł słownikowych, podaje się po tytule dzieła. W przypadku pozycji sygnowanych nazwiskiem autora po nazwisku przytaczano imię (imiona) w pełnym brzmieniu. W przypadku prac zbiorowych imię redaktora (redaktorów) i autorów haseł umieszczano przed nazwiskiem. Tytuły pozycji drukowanych w alfabetach innych aniżeli łaciński (oprócz cyrylicy) podaje się w transkrypcji, jaka ma zastosowanie w procedurze katalogowania bibliotecznego. W miejscu opisu bibliograficznego zamieszczono dane wydawcy, instytucji wydawniczej lub jej oddziału. W adresie bibliograficznym uwzględniano również kolejność wydań, nazwę serii i - każdorazowo - liczbę stron (z wyjątkiem niektórych publikacji w wersji elektronicznej online). Po adresie bibliograficznym, zwykle w nawiasach kwadratowych, umieszcza się informacje dodatkowe dotyczące zamieszczonego w publikacji indeksu rzeczowego, języków przekładu, przeznaczenia pracy, tytułu okładkowego, zapisów dodatkowych na stronach przytytułowych, informacji o innym tytule pierwszego / poprzedniego bądź oryginalnego wydania oraz adnotacje informujące o przeznaczeniu (typie) publikacji dla określonego odbiorcy. W przypadku zastosowania ekwiwalentnego tytułu (tytułów) innojęzycznego przytacza się obydwa bądź równoległe tytuły. W niektórych wypadkach w nawiasach kwadratowych przed adresem 
bibliograficznym podaje się nazwisko właściwe autora bądź jego zapis polskojęzyczny, jeśli w oryginale pojawił się zapis cyrylicki.

Sporządzony wykaz bibliograficzny słowników ma charakter użytkowy - z założenia winien służyć on jako przydatne, aktualne i łatwo dostępne informatorium. Korzystać z niego mogą nie tylko naukowcy, leksykografowie, ale też osoby doskonalące swe kompetencje językowe oraz tłumacze tekstów specjalistycznych.

\section{Bibliografia}

Anton Schneeberger. [W:] Internetowy polski słownik biograficzny. [Online:] <http://www.ipsb.nina. gov.pl/a/biografia/anton-schneeberger> (dostęp: 1.06.2017).

Bela Z. Etymologia i pierwotne znaczenia wyrazów lek i leczyć. „Gazeta Farmaceutyczna”, marzec 2011, s. 16-28. [Online:] <http://www.kwadryga.pl/upload/Dokumenty/Artykuly_naukowe/ GF_3_2011_naukowy.pdf> (dostęp: 25.08.2017).

Chodurska J. Ze studiów nad fitonimami rękopiśmiennych zielników wschodniosłowiańskich XVII-XVIII wieku. Seria Prace Monograficzne. Akademia Pedagogiczna im. Komisji Edukacji Narodowej w Krakowie, nr 360. Kraków: Wydawnictwo Naukowe Akademii Pedagogicznej, 2003.

Chodurska J. Nazwy roślin w rosyjskim tłumaczeniu „Zielnika” Szymona Syreniusza. [W:] W świecie Słowian. Szkice z dziejów leksykologii i leksykografii. Red. nauk. H. Chodurska, A. Mażulis-Frydel, A. Radzik. Kraków: Oficyna Wydawnicza Impuls, 2013, s. 47-64.

Jankowiak L.A. Słownictwo medyczne Stefana Falimirza. T. 1: Początki polskiej renesansowej terminologii medycznej. Instytut Slawistyki Polskiej Akademii Nauk. Towarzystwo Naukowe Warszawskie. Seria Język na Pograniczach, 27. Warszawa: Slawistyczny Ośrodek Wydawniczy, 2005.

Jankowiak L.A. Słownictwo medyczne Stefana Falimirza. T. 2: Słownik. Instytut Slawistyki Polskiej Akademii Nauk. Towarzystwo Naukowe Warszawskie. Seria Język na Pograniczach, 31. Warszawa: Slawistyczny Ośrodek Wydawniczy, 2006.

Karnecka M. Słownik Jana Stanki - najbogatszy zabytek przyrodniczy średniowiecza. „Rozprawy Komisji Językowej Wrocławskiego Towarzystwa Naukowego" 1976, t. 10, Wrocław, s. 119-155.

Katalog dzieł gospodarskich i nauk przyrodzonych, księgarni i składu nut muzycznych, G. Gebethnera i R. Wolffa. Warszawa: Krakowskie-Przedmieście nr 17, w Pałacu hr. Stan. Potockiego, 1861.

Mańkowski A. ks. Karol Ferdynand Ney. „Zapiski Towarzystwa Naukowego w Toruniu” 1925, t. VI, nr 11, s. 141-157.

Rogowska E. Kaszubskie nazwy roślin uprawnych. Gdańsk: Wydawnictwo Uniwersytetu Gdańskiego, 1998.

Szcześniak K. Świat roślin światem ludzi na pograniczu wschodniej i zachodniej Słowiańszczyzny. Wyd. 2 popr. Gdańsk-Sopot: Wydawnictwo Uniwersytetu Gdańskiego, 2013 (+ CD-ROM).

Waniakowa J. Polskie gwarowe nazwy dziko rosnacych roślin zielnych na tle słowiańskim. Zagadnienia ogólne. Kraków: Wydawnictwo Uniwersytetu Jagiellońskiego, 2012.

Waniakowa J. Osobliwe procesy fonetyczne $w$ gwarowych wyrazach zapożyczonych na przykładzie nazw roślin. [W:] Jazykovedné štúdie XXXII. Prirodzený vývin jazyka a jazykové kontakty. Ed. K. Balleková, G. Múcsková, L. Králik. Bratislava: Veda 2015, s. 203-210.

Zimny L. Leksykografia rolnicza. „Fragmenta Agronomica” 2008, nr 4. [Online:] <http://karnet. up.wroc.pl/ zimny/leksykografia.html> (dostęp: 6.08.2017). 


\section{Chronologiczny wykaz opracowań leksykograficznych z zakresu bota- niki wydanych w latach 1472-2017}

\section{2}

Stanko Jan. Antibolomenum (Antidotarium, Antibolarium) Benedicti Parthi. 1472 (rps) [kompendium sztuki medycznej, praktyk leczniczych i aptekarskich oraz ogromna encyklopedia minerałów, roślin; zawiera dawne nazwy chorób, części ciała, napojów i pokarmów używanych w lecznictwie; swoisty przewodnik po ówczesnej technice medycznej (opisy sprzętów i przyborów medycznych); zawiera 20000 synonimów łac., niem., grec. i arab., ok. 2000 synonimów pol.; 90 gatunków roślin zagranicznych i 433 gatunki krajowe; 219 krajowych gatunków zwierząt, w tym 88 gatunków ptaków].

\section{4}

Falimirz Stefan. O ziolach y o moczy gich (O paleniu wodek z ziol; O Oleykoch przyprawianiu; O Rzeczach zamorskich; O Zwierzętach, o Ptaszech, y o Ribach; O Kamieniu drogim; O Urinie, o Pulsie; Y o inych znamionach; O Rodzeniu dziatek; O Naucze gwiazdeczney; O stawianiu baniek; Y o puszczaniu krwie; O Rządzeniu czasu powietrza morowego; O lekarstwiech doswiadczonych na wiele niemoczy; O Naucze Barwierzkiey). Cracouiae: Florian Vnglerius [...], Imprimował 24 XII 1534, ss. [36], 156, 32, [1], 42, 59, [1], 119, [1] k.

\section{2}

Spiczyński Hieronim. O Ziolach tutecznych y zamorskich y o mocy ich, a kthemu kxiegi lekarskie wedle regestru niżey nowo wypisanego wssem wielmi vzyteczne. [Var. B], Cracouiae: apud viduam Floriani Vnglerij, 1542, ss. [12], 247 [zawiera słowniczek polsko-łaciński Regestr o ziołach].

\section{6}

Schneeberger Anton. Medicamentorum simplicium corpus humanum a pestilentiae contagione praeservantium catalogus: et quomodo iis utendum sit brevis institutio : apposita sunt etiam stirpium nomina Polonica: ubi plurima antehac ab aliis in re herbaria recte scripta breviter continentur..., Cracouiae: Apud Lazarum Andreae, 1556, ss. [56].

Spiczyński Hieronim. O Ziolach tutecznych y zamorskich y o mocy ich, a kthemu kxiegi lekarskie wedle regestru niżey nowo wypisanego wssem wielmi vzyteczne. [Var. B], Craccoviae: Apud Hæredes Marci Scharfenberger, 1556, ss. [16], 247 [i.e. 245, [1 cz.] [zawiera słowniczek polsko-łaciński Regestr o ziołach].

1557

Schneeberger Anton. Catalogus stirpium quarundam latine et polonice conscriptus. Cracoviae: Lazarus Andreae Imprefsit, 1557. 


\section{8}

[Marcin Siennik]. Herbarz to iest, Zioł tutecznych, postronnych, y Zamorskich opisanie. Co za moc maia, a iako ich uzywać, tak ku przestrzeżeniu zdrowia ludzkiego, iako ku vzdrovienia rozmaitych chorob. Teraz nowo, wedle Herbarzow dzisieyszego wieku, y inych zacnych Medykow, poprawiony. Przydano Alexego Pedemontana Ksiegi ośmiory, o taiemnych a skrytych Lekarstwiech (...); Co sie w tych Księgach więcey opisuie (...) Regestra dostateczne na koncu snadnieć pokaża. W Krakowie: w Drukarni Mikołaia Szarffenberga, [post 16 VI ] (1568), k. [6], ss. 628, [51, 1 cz.].

\section{5}

[Marcin z Urzędowa]. Herbarz Polski, To iest O Przyrodzeniv Zioł Y Drzew Rozmaitych, Y Innych Rzeczy Do Lekarztw Należacych, Księgi Dwoie, Doctora Marcina Vrzedowa (...). [Ed. Ian Firlewicz]. W Krakowie: w Drukarni Łazarzowey, [post 9 VII] 1595 , ss. [4], 488, [1, 1 cz.].

\section{3}

[Syreński Szymon]. Zielnik Herbarzem z ięzyka Łacinskiego zowią To iest Opisanie własne imion, kształtu, przyrodzenia, skutkow, y mocy Zioł wszelakich Drzew Krzewin y korzenia ich, Kwiatu, Owocow, Sokow Miasg, Zywic y korzenia do potraw zaprawowania Takze Trunkow, Syropow, Wodek Lekiwarzow, Konfektow [...] pilnie zebrane a porzadnie zapisane przez D. Simona Syrennivsa. Cracoviae: (w Drukarni Bazylego Skalskiego), [III] 1613, ss. [11] k., 1540 [i.e. 1544] s., [12] k.

\section{7}

Roslin Potrzebnych, Pozytecznych, Wygodnych, Osobliwie Kraiowych, Albo Ktore W Kraiu Uzyteczne Byc Moga, Utrzymanie, Rozmnozenie I Zazycie. T. 1: O Drzewach, Ziołach Ogrodowych i Ogrodach z Figurami. Przez X. Krzysztofa Kluka (...). W Drukarni J. K. Mci i Rzeczypospolitey u XX. Scholarum Piarum. W Warszawie Roku 1777, k. [2], ss. [8], 322, k. [4] [zawiera: Cz. 1-5 z tyt. nagł. oraz Kalendarz Albo Przypomnienia Robot Rocznych W Ogrodach, s. 310-322; indeksy].

Roslin Potrzebnych, Pozytecznych, Wygodnych, Osobliwie Kraiowych, Albo Ktore W Kraiu Uzyteczne Byc Moga, Utrzymanie, Rozmnozenie I Zazycie. Tom (...) Z Figurami. T. 1: O Drzewach, Ziołach Ogrodowych i Ogrodach. Przez X. Krzysztofa Kluka (...). W Drukarni J. K. Mci i Rzeczypospolitey u XX. Scholarum Piarum. W Warszawie Roku 1777, k. [6], ss. 342 [i.e. 340], k. [1], tabl. VIII [zawiera. Cz. 1-5 z tyt. nagł. oraz Kalendarz Albo Przypomnienia Robot Rocznych W Ogrodach, ss. 329-342, na ost. k. Omyıki; indeksy].

\section{8}

Roslin Potrzebnych, Pozytecznych, Wygodnych, Osobliwie Kraiowych, Albo Ktore W Kraiu Uzyteczne Byc Moga, Utrzymanie, Rozmnozenie I Zazycie, Tom (...) Z Figurami. T. 2: O Drzewach I Ziołach Dzikich, Lasach etc. Przez X. Krzysztofa Kluka (...). W Drukarni J. K. Mci i Rzeczypospolitey u XX. Scholarum Piarum. W Warszawie 1778, k. [6, 1-sza cz.], ss. 307, [1], k. [1], tabl. V [na k. przedtyt.: O Roslinach Ich Utrzymaniu, Rozmnozeniu I Zazyciu. Tom 2; indeksy]. 


\section{9}

Roslin Potrzebnych, Pozytecznych, Wygodnych, Osobliwie Kraiowych, Albo Ktore W Kraiu Uzyteczne Byc Moga, Utrzymanie, Rozmnozenie I Zazycie, Tom (...) Z Figurami. T. 3: O Rolnictwie, Zbozach, Łąkach, Chmielnikach, Winnicach y Roslinach Gospodarskich. Przez X. Krzysztofa Kluka (...). W Drukarni J. K. Mci i Rzeczypospolitey u XX. Scholarum Piarum, W Warszawie 1779, k. [6], ss. 378, [1], k. [1], tabl. IV [na k. przedtyt.: O Roslinach Ich Utrzymaniu, Rozmnozeniu I Zazyciu. Tom 3; indeks].

\section{1}

Roslin Potrzebnych, Pozytecznych, Wygodnych, Osobliwie Kraiowych, Albo Ktore W Kraiu Uzyteczne Byc Moga, Utrzymanie, Rozmnozenie I Zazycie, Tom (...) Z Figurami. T. 3: O Rólnictwie, Zbozach, Łąkach, Chmielnikach, Winnicach y Roslinach Gospodarskich. Przez X. Krzysztofa Kluka (...). W Drukarni J. K. Mci i Rzeczypospolitey u XX. Scholarum Piarum. W Warszawie 1781, k. [2], ss. [8], 362, k. [2], [indeksy].

\section{5}

Botanika dla Szkół Narodowych, [podług Prospektu J P. Pawła Czenpinskiego, (...) przez J X. Krzysztofa Kluka (...) napisane, od Towarzystwa do Xiąg Elementarnych roztrząśnione]. Pierwszy raz wydana, [Var. A]. w Drukarni Nadworney J. K. Mci i P. Kom. E. N., W Warszawie [post 14 I] 1785, k. [1], ss. 238, k. [1], tabl. VI [Słowniczek botaniczny polsko-łaciński (s. 229-238)].

\section{6}

Dykcyonarz Roślinny W Którym Podług Układu Linneusza Są Opisane Rosliny Nietylko Kraiowe Dzikie, Pozyteczne, Albo Szkodliwe Na Roli, W Ogrodach, Oranzeryach Utrzymywane Ale Oraz Y Cudzoziemskie, Ktoreby W Kraiu Pożyteczne Byc Mogły Albo Z Ktorych Mamy Lekarstwa, Korzenie, Farby, \&c. Albo Ktore Jakowa Nadzwyczaynosc W Sobie Maia Ich Zdatnosci Lekarskie, Ekonomiczne, Dla Ludzi, Koni, Bydła, Owiec, Pszczoł, \&c. Utrzymywanie, \&c. Z poprzedzaiacym wykładem słow Botanicznych y kilkorakim na końcu Regestrem. T. 1: A-E. Ułożony Przez X. Krzysztofa Kluka (...). W Drukarni J. K. Mci y Rzeczypospolitey u XX. Scholarum Piarum. W Warszawie 1786, k. [1], ss. XLII, [1 cz.], ss. 214, k. [1].

\section{7}

Dykcyonarz Roślinny W Którym Podług Układu Linneusza Są Opisane Rosliny Nietylko Kraiowe Dzikie, Pozyteczne, Albo Szkodliwe Na Roli, W Ogrodach, Oranzeryach Utrzymywane Ale Oraz Y Cudzoziemskie, Ktoreby W Kraiu Pożyteczne Byc Mogły Albo Z Ktorych Mamy Lekarstwa, Korzenie, Farby, \&c. Albo Ktore Jakowa Nadzwyczaynosc W Sobie Maia Ich Zdatnosci Lekarskie, Ekonomiczne, Dla Ludzi, Koni, Bydła, Owiec, Pszczoł, \&c. Utrzymywanie, \&c. Z poprzedzaiacym wykładem słow Botanicznych y kilkorakim na końcu Regestrem. T. 2: F-Q. Ułożony Przez X. Krzysztofa Kluka (...). W Drukarni J. K. Mci y Rzeczypospolitey u XX. Scholarum Piarum. W Warszawie 1787, k. [1], ss. 256. 


\section{8}

Dykcyonarz Roślinny W Którym Podług Układu Linneusza Sa Opisane Rosliny Nietylko Kraiowe Dzikie, Pozyteczne, Albo Szkodliwe Na Roli, W Ogrodach, Oranzeryach Utrzymywane Ale Oraz Y Cudzoziemskie, Ktoreby W Kraiu Pożyteczne Byc Mogły Albo Z Ktorych Mamy Lekarstwa, Korzenie, Farby, \&c. Albo Ktore Jakowa Nadzwyczaynosc W Sobie Maia Ich Zdatnosci Lekarskie, Ekonomiczne, Dla Ludzi, Koni, Bydła, Owiec, Pszczoł, \&c. Utrzymywanie, \&c. Z poprzedzaiacym wykładem słow Botanicznych y kilkorakim na końcu Regestrem. T. 3: R-Z. Ułożony Przez X. Krzysztofa Kluka (...). W Drukarni J. K. Mci y Rzeczypospolitey u XX. Scholarum Piarum. W Warszawie 1788, k. [1], ss. 172, k. [39] [Regestr Imion Roślinnych (...) w języku łacińskim i polskim, Regestr Roślin zdatnych do rożnego zażycia ekonomicznego; Regestr Roślin zdatnych do zażycia Lekarskiego; Gromady, Rzędy I Rodzaie Roslin (...)].

\section{2}

Roslin potrzebnych, pozytecznych, wygodnych, osobliwie kraiowych, albo które w kraiu użyteczne bydź moga, utrzymanie, rozmnozenie i zazycie. T. 2: O drzewach, i ziołach dzikich, lasach. Przez Krzysztofa Kluka. Przedrukowany w Warszawie. Warszawa: w Drukarni Xięży Piiarów, 1802, ss. [8], 288.

Roslin potrzebnych, pozytecznych, wygodnych, osobliwie kraiowych, albo które $w$ kraiu użyteczne bydź moga, utrzymanie, rozmnozenie i zazycie. T. 3: O rolnictwie, zbożach, łąkach, chmielnikach, winnicach i roslinach gospodarskich. Przez Krzysztofa Kluka. Ed. 2. Warszawa: w Drukarni Xięży Piiarów, 1802 ss. [8], 352, k. [2].

\section{3}

Dykcyonarz roślinny, w którym podług układu Linneusza sa opisane rośliny nietylko kraiowe dzikie, pożyteczne, albo szkodliwe (...) i cudzoziemskie (...), albo z ktorych mamy lekarstwa, korzenie, farby, (...) albo ktore jakowa nadzwyczajność $w$ sobie maja (...) z poprzedzaiącym wykładem słów botanicznych, i kilkokrotnym na końcu reiestrem. T. 2: F-K. Ułożony przez Krzysztofa Kluka. Przedrukowany w Warszawie. Warszawa: w Drukarni Xięży Piarów, 1803, k. 1, ss. 256.

\section{4}

Dykcyonarz roslinny, w którym podług układu Linneusza sa opisane rośliny nie tylko kraiowe dzikie, pożyteczne, albo szkodliwe: na roli, w ogrodach, oranżeryach, utrzymywane: ale oraz i cudzoziemskie, ktoreby $w$ kraiu pożyteczne byc mogły: albo z ktorych mamy lekarstwa, korzenie, farby, it. d. albo ktore jakowa nadzwyczaynosc w sobie maią: ich zdatności lekarskie, ekonomiczne dla ludzi, koni, bydła, owiec, psczoł, it. d. utrzymywanie, i t. d. T. 3: R-Z. Ułożony przez X. Krzysztofa Kluka. Przedrukowany w Warszawie. Warszawa: w Drukarni Xięży Piarów, 1804, ss. [4], 192, 74] [na s. tyt.: Z poprzedzaiącym wykładem słów botanicznych i kilkokrotnym na końcu reiestrem; indeksy].

Historya naturalna kraiu polskiego czyli Zbior krótki przez Alfabet ułożony, Zwierząt, Roślin, i Minerałow znayduiących się w Polszcze i Litwie: zebrana z pisarzów godnych wiary, z rękopismow i świadkow oczywistych. T. 1. Przez Ładowskiego. Wyd. 2. 
Kraków: w Drukarni Antoniego Gröbla pozostałey Wdowy i Sukcessorow, 1804, ss. 340, [26].

Historya naturalna kraiu polskiego czyli Zbior krótki przez Alfabet ułożony, Zwierząt, Roślin, i Minerałow znayduiących się w Polszcze i Litwie: zebrana $z$ pisarzów godnych wiary, z rękopismow i świadkow oczywistych. T. 2. Przez Ładowskiego. Wyd. 2. Kraków: w Drukarni Antoniego Gröbla pozostałey Wdowy i Sukcessorow, 1804, ss. 378, [29].

\section{5}

Dykcyonarz roslinny, w którym podług układu Linneusza sq opisane rosliny nietylko kraiowe dzikie, pożyteczne, albo szkodliwe: na roli, w ogrodach, oranżeryach, utrzymywane: ale oraz i cudzoziemskie, ktoreby w kraiu pożyteczne być mogły: albo z ktorych mamy lekarstwa, korzenie, farby, i t.d. albo ktore jakowa nadzwyczaynosc w sobie maia: ich zdatnosci lekarskie, ekonomiczne, dla ludzi, koni, bydła, owiec, pszczoł, $i$ t.d. utrzymywanie, i t.d. z poprzedzaiacym wykładem słów botanicznych, i kilkokrotnym na końcu reiestrem. T. 1: A-E. Ułożony przez X. Krzysztofa Kluka. Warszawa: w Drukarni Xięży Piarów, 1805, ss. [4], XLII, 214, [2].

\section{8}

Dykcyonarz roslinny, w którym podług układu Linneusza sa opisane rosliny nietylko kraiowe dzikie, pożyteczne, albo szkodliwe: na roli, w ogrodach, oranżeryach, utrzymywane: ale oraz i cudzoziemskie, ktoreby $w$ kraiu pożyteczne być mogły: albo z ktorych mamy lekarstwa, korzenie, farby, i t.d. albo ktore jakowa nadzwyczaynosc w sobie maia: ich zdatnosci lekarskie, ekonomiczne, dla ludzi, koni, bydła, owiec, pszczoł, i t.d. utrzymywanie, i t.d. z poprzedzaiacym wykładem słów botanicznych, i kilkokrotnym na końcu reiestrem. T. 2: F-Q. Ułożony przez X. Krzysztofa Kluka. Warszawa: w Drukarni Xięży Piarów, 1808, ss. [4], 256, [2].

Roślin potrzebnych, pozytecznych, wygodnych, osobliwie kraiowych, albo które w kraiu użyteczne bydź moga, utrzymanie, rozmnozenie i zazycie. T. 1: O roślinach, ich utrzymaniu, rozmnozeniu i zazyciu. Przez Krzysztofa Kluka, Warszawa: w Drukarni XX. Piarów, Warszawa, 1808, ss. 307, [7], k. [4].

Schultes Joseph Aaugust. Catalogus Plantarum Horti botanici C. R. Universatis Cracoviensis. Cracoviae: [s.n.], 1808, ss. 82.

\section{1}

Dykcyonarz roslinny, w którym podług układu Linneusza sa opisane rosliny nietylko kraiowe dzikie, pożyteczne, albo szkodliwe: na roli, w ogrodach, oranżeryach, utrzymywane: ale oraz i cudzoziemskie, ktoreby $w$ kraiu pożyteczne być mogły: albo z ktorych mamy lekarstwa, korzenie, farby, i t.d. albo ktore jakowa nadzwyczaynosc w sobie maia: ich zdatnosci lekarskie, ekonomiczne, dla ludzi, koni, bydła, owiec, pszczol, i t.d. utrzymywanie, i t.d. z poprzedzaiacym wykładem słów botanicznych, i kilkokrotnym na końcu reiestrem. T. 3: R-Z. Ułożony przez X. Krzysztofa Kluka. Warszawa: w Drukarni Xięży Piarów, 1811, ss. 196, [70] [indeksy]. 
1824

Günther Carl Christian, Grabowski Heincrich Emmanuel, Wimmer Friedrich. Enumeratio stirpium phanerogamarum, quae in Silesia sponte proveniunt. Vratislaviae: apud Guilielmum Theophilum Korn, 1824, ss. VIII, 168 [spisy].

Spis roślin Ogrodu Botanicznego Krolewskiego-Warszawskiego Uniwersytetu. Wydany przez Michała Szuberta. Warszawa: Drukarnia Szkolna, 1824, ss. [2], XLIV, 583, [5], k. tabl. [1].

\section{5}

Nauka wyrazów botanicznych dla łatwości determinowania roślin, czyli zastosowania do nich opisów z naylepszych autorów krotko zebrana i porzadkiem abecadła ułożona, przez Antoniego Andrzejowskiego. Krzemieniec-Warszawa: nakł. i drukiem N. Glücksberga, 1825, ss. [4], XXXVI, 247, [1], XVII.

\section{7}

Andrzejowski Antoni, Nazwiska roślin Grekom starożytnym znanych na język polski przettumaczone, Wilno: [s.n.], 1827, ss. 12 [Pomnożenie Dykcjonarza roślinnego ś.p. Krzysztofa Kluka [rel.]. Wilno: W.S.J.G. Besser, 1827, ss. 22].

Flora Silesiae. Ps. 1: Cl. I-X, scripserunt Fr. Wimmer et H. Grabowski. Vratislaviae: apud Guilelmum Theophilum Korn, 1827, ss. XVI, 446, k. [1] [spis].

Spis roślin trebhauzowych, oranżeryowych i niektórych gruntowych, rozmożonych $w$ Ogrodzie Botanicznym Warszawskim w roku 1827 = Plantes de serre chaude, de serre froide et quelques unes de pleine terre multipliées au jardin des Plantes de Varsovie an 1827. Warszawa: [s.n.], 1827, ss. 23.

\section{9}

Flora Silesiae. Ps. 2. Vol. 1: Cl. XI-XV, scripserunt Fr. Wimmer et H. Grabowski, Vratislaviae: apud Guilelmum Theophilum Korn, 1829, ss. [2], XXIV, 282, [2], k. [1] [spis].

Flora Silesiae. Ps. 2. Vol. 2: Cl. XVI-XXII, scripserunt Fr. Wimmer et H. Grabowski, Vratislaviae: apud Guilelmum Theophilum Korn, 1829, ss. [4], 400 [spis].

\section{0}

Słownik wyrazów botanicznych, przez Alexandra Pławskiego. Wilno: wydał Józef Zawadzki własnym nakładem, 1830, ss. VIII, 298, [1].

\section{4}

Catalogus plantarum quae in caldariis, tepidariis frigidariisque horti botanici Academiae Cesareae Medico-Chirurgicae Vilnensis, reperiuntur: anno millesimo octingentesimo trigesimo quatro concinnatus. [S.l.: s.n., ca 1834], ss. 84.

\section{8}

Teichler. Spis ogolny strojnych roślin ogrodu niedźwiedzkiego na przedarz wystawionych aż po 1-o czerwca 1838 roku. Kraków: w Drukarni J. Czecha, 1838, ss. 51. 


\section{1}

Kwiaty czyli Wykład znaczeń blisko tysiąca roślin krajowych i zagranicznych w języku polskim, łacińskim i niemieckim spisanych. Ku użytkowi i zabawie płci obojej ułożył Dr. N [krypt.] [właśc. Karol Ney], Poznań: E.S. Mittler, 1841 (Poznań: W. Decker i Spółka), ss. [1], VII, 152.

\section{4}

Moralne abecadło ogrodowe czyli Paulin, ogrodnikś. w winnicy Pańskiej. Powieść z dawnych czasów chrześciańskich. Napisał dla użytku młodzieży szkólnéj Józef Ried. Z niem przeł. Piotr Guhra. Leszno - Gniezno: nakł. i drukiem Ernesta Günthera, 1844, ss. 4, IV, 84.

\section{5}

Dykcyonarz roślinny, w którym podług układu Linneusza są opisane rośliny nietylko kraiowe dzikie, pożyteczne, albo szkodliwe (...) i cudzoziemskie (...), albo z ktorych mamy lekarstwa, korzenie, farby, (...) albo ktore jakowa nadzwyczajność w sobie maja (...) z poprzedzaiącym wykładem słów botanicznych, i kilkokrotnym na końcu reiestrem. T. 2: F-Q. Ułożony przez Krzysztofa Kluka. Warszawa: w Drukarni XX. Piiarów, 1845, ss. [2], 256.

Zielnik ekonomiczno-techniczny: czyli opisanie drzew, krzewów i roślin dziko rosnacych $w$ kraju, jako też przyswojonych, $z$ pokazaniem użytku ich $w$ ekonomice, rękodziełach, fabrykach i medycynie domowej, z wyszczególnieniem jadowitych i szkodliwych [...] ułożony dla gospodarzy i gospodyń. T. 1. Przez Józefa Gerald-Wyżyckiego. Wilno: nakładem autora, 1845, ss. XII, 407.

Zielnik ekonomiczno-techniczny: czyli opisanie drzew, krzewów i roślin dziko rosnacych $w$ kraju, jako też przyswojonych, $z$ pokazaniem użtku ich $w$ ekonomice, rękodziełach, fabrykach i medycynie domowej, z wyszczególnieniem jadowitych i szkodliwych [...] ułożony dla gospodarzy i gospodyń. T. 2. Przez Józefa Gerald-Wyżyckiego. Wilno: nakładem autora, 1845 , ss. 555, [1] k.

\section{6}

Dykcyonarz roślinny, w którym podług układu Linneusza sa opisane rośliny nietylko kraiowe dzikie, pożyteczne, albo szkodliwe (...) i cudzoziemskie (...), albo z ktorych mamy lekarstwa, korzenie, farby, (...) albo ktore jakowa nadzwyczajność $w$ sobie maja (...) z poprzedzaiącym wykładem słów botanicznych, i kilkokrotnym na końcu reiestrem. T. 3: $R-Z$. Ułożony przez Krzysztofa Kluka. Warszawa: w Drukarni XX. Piiarów, 1846, ss. 270.

\section{9}

Waga Jakób. Flora polska. Rejestra = Flora Polonica. Indices, Ukaziciel polskich nazwisk na rodzaje królestwa roślinnego, ułożony abecadłowo najprzód od łacińskich do polskich, a powtóre od polskich do łacińskich, dla użytku botaników, ogrodników, rolników, farmaceutów i wszystkich miłośników roślin. Przez Antoniego Wagę. Warszawa: Klukowski, 1849 (Warszawa: druk Strąbskiego), ss. [3], 682-820, [3], XXX, [2], 336. 


\section{1}

Kwiaty czyli Wykład znaczeń blisko tysiąca roślin krajowych i zagranicznych w języku polskim, łacińskim i niemieckim spisanych. Ku użytkowi i zabawie płci obojej ułożył Dr. N [krypt.] [właśc. Karol Ney]. [Wyd. 2]. Leszno: Ernest Günther, ss. [1], VII, 152.

\section{2}

Opisanie roślin jednolistniowych lékarskich i przemysłowych. Przez Ignacego Raf. Czerwiakowskiego. Seria Botanika szczególna, przez Ignacego Raf. Czerwiakowskiego, cz. 2, Biblioteka Naukowa, Towarzystwo Naukowe z Uniwersytetem Jagiellońskim Złączone. Kraków: W Drukarni Uniwersytetu, 1852, s. [4], 264-821 [Spis abecadłowy polski nazwisk-roślin, ich różnych działów, płodów lékarskich i przemysłowych, oraz nowszych narzędzi roślinnych].

\section{9}

Opisanie roślin dwulistniowych lékarskich i przemysłowych. Przez Ignacego Raf. Czerwiakowskiego. Seria Botanika szczególna, przez Ignacego Raf. Czerwiakowskiego, cz. 3, Biblioteka Naukowa, C. K. Towarzystwo Naukowe Krakowskie. Kraków: W Drukarni C. K. Uniwersytetu, 1859, s. [4], 824-1543 [Spis abecadłowy polski nazwisk-roślin, ich różnych działów, płodów lékarskich i przemysłowych, oraz narzędzi roślinnych. Cz. 3 obejmuje: Dwulistniowe Zdrożne, Bezpłatkowe i Jednopłatkowe nadjajnikowe aż po rodzinę Szorstkolistnych - wyłącznie].

Opisanie roślin dwulistniowych lékarskich i przemysłowych. Przez Ignacego Raf. Czerwiakowskiego. Seria Botanika szczególna, przez Ignacego Raf. Czerwiakowskiego, cz. 4, Biblioteka Naukowa, C. K. Towarzystwo Naukowe Krakowskie, Kraków: W Drukarni C. K. Uniwersytetu, 1859, s. [4], 1545-2254 [Spis abecadłowy polski nazwisk-roślin, ich różnych działów, płodów lékarskich i przemysłowych, oraz narzędzi roślinnych. Cz. 4 obejmuje: Rośliny od rodziny Szorstkolistnych włącznie, az do Wielopłatkowych podjajnikowych wyłacznie].

\section{0}

Opisanie roślin dwulistniowych lékarskich i przemysłowych. Przez Ignacego Raf. Czerwiakowskiego. Seria Botanika szczególna, przez Ignacego Raf. Czerwiakowskiego, cz. 5, Biblioteka Naukowa, C. K. Towarzystwo Naukowe Krakowskie, Kraków: W Drukarni C. K. Uniwersytetu, 1860, s. [4], 2255-2953 [Spis abecadłowy polski nazwisk-roślin, ich różnych działów, płodów lekarskich i przemysłowych, oraz narzędzi roślinnych. Cz. 5 obejmuje: Rośliny Wielopłatkowe podjajnikowe].

Waga Antoni, Atlas historyi naturalnej z 222 kolorowanemi wizerunkami i ze szczegółowym tekstem do każdego wizerunku z polsko-łacińsko-francusko-niemiecka nomenklatura przedmiotów. Warszawa: Litografia J. Odessera, 1860, ss. [4], IV, 191.

\section{3}

Opisanie roślin dwulistniowych lékarskich i przemysłowych. Przez Ignacego Raf. Czerwiakowskiego. Seria Botanika szczególna, przez Ignacego Raf. Czerwiakowskiego, cz. 6, Biblioteka Naukowa, C. K. Towarzystwo Naukowe Krakowskie. Kraków: 
W Drukarni C. K. Uniwersytetu, 1863, s. [4], 2956-3545 [Spis abecadłowy polski nazwisk-roślin, ich różnych działów, płodów lékarskich i przemysłowych, oraz narzędzi roślinnych. Cz. 6 obejmuje: Rośliny Wielopłatkowe kołojajnikowe].

\section{1}

Historyja roślin. T. 3: Obejmujący rodziny skryptopłciowe, wiadomość o drzewach olbrzymich. Wykaz roślin używanych przez Tł. uzup. geografiją botaniczną, dodatek i t. d., przez Ludwika Figuier. Z fr. przeł., objaśnił i licznemi dodatkami powiększył autor Flory polskiej [Jakub Waga]. Warszawa: Drukarnia Józefa Ungra, 1871, ss. [4], 258, LXXIII, 10, [1].

\section{0}

Spis roślin naczyniowych z okolicy Przemyśla. Podał B. Kotula. Kraków: w Drukarni Uniwersytetu Jagiellońskiego, 1880, ss. 90 [Odbicie: „Sprawozdania Komisyi fizyjograficznej Akademii Umiejętności”, t. 14].

\section{1}

Wykaz roślin naczyniowych zebranych przez dr A. Rogalskiego i I. Szyszyłowicza w Wapiennych Tatrach Spiskich r. 1878. Zestawił A. Rogalski. Kraków: [s.n.], 1881, ss. [2], 37 [osobne odbicie ze „Sprawozdań Komisyi fizyjograficznéj Akademii Umiejętności”, t. XV].

\section{2}

Podręcznik botaniczny kieszonkowy, dla ogrodniczków polskich do uczenia się nazwisk roślin pożytecznych... Zebrał i ułożył Józef Borecki, Łowicz: [s. n.], 1882, ss. [2], 82, [3].

\section{3}

Spis roślin jawnopłciowych rosnacych $w$ okolicach miasta Międzyrzeca, położonego w Gubernii Siedleckiéj, powiecie Radzyńskim. Podał B. Eichler. Varšava: Drukarnia J. Bergera, 1883, ss. 12 [odbicie „Pamiętnik Fizyjograficzny”, t. 3, 1883].

Spis roślin znalezionych $w$ okolicy Szemetowszczyzny na Litwie. Przez Maryją Twardowską. Warszawa: [s.n.], 1883 (Warszawa: Drukarmia J. Bergera), ss. 18 [odbicie: „Pamiętnik Fizjograficzny”, t. 3 za rok 1885].

\section{5}

Spis roślin znalezionych $w$ okolicy Szemetowszczyzny na Litwie. Przez Maryją Twardowską. Warszawa: [s.n.], 1883 (Warszawa: Drukarnia J. Bergera), ss. 18 [odbicie: „Pamiętnik Fizjograficzny”, t. 3 za rok 1885].

Spis roślin jawnokwiatowych dziko rosnacych $w$ Stupi-Nadbrzeżnéj, zebranych przez Maryją Hempel. Warszawa: Drukarnia E. Skiwskiego, 1885, ss. 19 [odbicie z „Pamiętnika Fizjograficznego", t. 5 za r. 1885].

Spis roślin znalezionych przez profesora Stanisława Cyrynę Dogiela z uczniami Szkoły Wojewódzkiej Sejneńskiej, w okolicach Sejn, od r. 1827-1830. Podał J. Rostafiński. Warszawa: [s.n.], 1885 (Warszawa: Drukarnia E. Skiwskiego), ss. 20 [opracowa- 
nie materiału botanicznego zawartego w rozprawie S. Dogiela „Uwagi nad istotami przyrodzonemi, a szczególnie nad roślinami” zawartej w sprawozdaniu „Popis uczniów Szkoły wojewódzkiej Sejneńskiej dnia 26 i 27 lipca (...)”, Suwałki 1830; Odb.: „Pamiętnik Fizjograficzny”, t. 5 za rok 1885].

Spis rzadszych roślin jawnokwiatowych rosnacych $w$ Teresinie, zebranych przez Maryją

Hempel. Warszawa: Drukarnia E. Skiwskiego, 1885, ss. 6 [odbicie z „Pamiętnika Fizjograficznego", t. 5 za r. 1885].

\section{7}

Przyczynek do znajomości wątrobowców (Hepaticae) południowo-zachodniej Polski. Podał Maryan Raciborski. Kraków: Drukarnia Uniwersytetu Jagiellońskiego pod zarządem A. M. Kosterkiewicza, 1887, ss. 6 [odbicie: „Sprawozdania Komisyi fizyjograficznej Akademii Umiejętności”, t. XXII; spisy].

\section{8}

Гагман К.М. вон. Сельско-хозяйственный гербарий. Краткое наставление к составлению гербария с приложением алфавитных списков русско-латинских и латинско-русских названий (...) доклад Лохвицкому Обществу Сельских Хозяеи в сентябре 1887 года. Poltava: [s.n.], 1888, ss. 13, [1], 25, [3], k. tabl. [1].

\section{9}

Słownik nazwisk zoologicznych i botanicznych polskich, zawierajacy ludowe oraz naukowe nazwy i synonimy polskie, używane dla zwierząt i roślin od XV-go wieku do chwili obecnej. Źródłowo zebrane i zestawione z synonimami naukowemi łacińskiemi w podwójnym porządku alfabetycznym i pomnożone porównawczym materyałem, zaczerpniętym $z$ innych języków słowiańskich [= Dictionnaire latin-polonais augmenté de la nomenclature de plusieurs langues slaves]. T. 1: Słownik polsko-łaciński. Ułożył Erazm Majewski, Warszawa: nakł. prenumeratorów, 1889, ss. LXIV, 546, 2 [na okł. r. wyd.: 1894, Drukarnia Rubieszewski i Wrotnowski].

\section{2}

Zielnik czyli dokładny opis ziół leczniczych, z których robienie skutecznych lekarstw podane jest w poradniku dla zdrowych i chorych napisanym przez księdza Seb. Kneippa, a mianowicie w części II-giej obejmującej apteke domowa opracowana przez dr. Walsera: z 50-ciu rycinami. Rośliny opisał, jako i rejestr polskich, niemieckich i łacińskich nazw zestawił B. T. Poznań: nakładem Księgarni Katolickiej, 1892 (Poznań: czcionkami Drukarni Dziennika Poznańskiego), ss. V, 93.

Zielnik czyli Atlas roślin leczniczych znachodzacych się w Kneippa „Aptece domowej”, (cz. II „Moje leczenie woda”): zawiera wierne ryciny obrazowe roślin leczniczych polecanych $w$ książkach ks. Kneippa, i niektórych używanych często przez lud. Tł. J. A. Ł. [Julian Antoni Łukaszkiewicz]. Wyd. 2 (kolorowy światłodruk). Kempten (Bawarja): nakł. Księgarni Józefa Kösela, 1892, ss. XII, [92] s., XLI k. tabl. 
1893

Ciag dalszy spisu roślin z okolic Szemetowszczyzny i z Weleśnicy. Przez Maryą Twardowską. Warszawa: [s.n.], 1893 (Warszawa: Drukiem Emila Skiwskiego), ss. 10 [odbicie „Pamiętnik Fizjograficzny”, t. 12 za rok 1892].

\section{4}

Słownik nazwisk zoologicznych i botanicznych polskich, zawierajacy ludowe oraz naukowe nazwy i synonimy polskie używane dla zwierząt i roślin od XV-go wieku aż do chwili obecnej, źródłowo zebrane i zestawione z synonimami naukowemi łacińskiemi w podwójnym porządku alfabetycznym i pomnożone porównawczym materyałem zaczerpniętym z innych języków słowiańskich. T. 1: Słownik polsko-łaciński [= Dictionnaire des noms polonais zoologiques et botaniques contenant les noms vulgaires et littéraires polonais, donnés aux animaux et aux plantes dèpuis le XV siècle jusqu'a nos jours. Vol. 1: Dictionaire polonais-latin]. Zebrał i ułożył Erazm Majewski. Warszawa: nakł. prenumeratorów - Skład Główny i Ekspedycya w Księgarni E. Wendego i S-ki, 1894 (Warszawa: Drukarnia Rubieszewskiego i Wrotnowskiego], ss. LXIV, 546, [2].

Słownik nazwisk zoologicznych i botanicznych polskich, zawierający ludowe oraz naukowe nazwy i synonimy polskie, używane dla zwierzat i roślin od XV-go wieku do chwili obecnej. Źródłowo zebrane i zestawione z synonimami naukowemi łacińskiemi $w$ podwójnym porządku alfabetycznym i pomnożone porównawczym materyałem, zaczerpniętym z innych języków słowiańskich. T. 2: Słownik łacińsko-polski pomnożony prównawczym materyałem, zaczerpniętym z innych języków słowiańskich. Cz. 1: A-M [= Dictionnaire des noms Polonais zoologiques et botaniques contenant les noms vulgaires et littéraires Polonais, donnés aux animaux et aux végétaux depuis le XV-me siècle jusqu'a nos jours. Vol. 2: Dictionaire latin-polonais. Pt. 1: A-M ]. Ułożył Erazm Majewski. Warszawa: nakł. autora, 1894, ss. [4], XLVII, XI, 888, [2] [na okł. r. wyd.: 1898, Drukarnia Rubieszewski i Wrotnowski].

\section{5}

Zielnik czarodziejski to jest Zbiór przesądów o roślinach. Przez Józefa Rostafińskiego. Kraków: nakł. Akademii Umiejętności, 1895 (Kraków: Drukarnia Uniwersytetu Jagiellońskiego), ss. [4], 191.

\section{6}

Spis roślin zebranych w pow. Dziśnieńskim w latach 1892 i 1893. Podała A. Missuna. Warszawa: Drukarnia Artystyczna Saturnina Sikorskiego, 1896, s. [95]-113 [nadb.: „Pamiętnik Fizyograficzny”, t. 14, 1896].

Spis roślin zebranych z Szemetowszczyzny i $z$ Weleśnicy w latach 1893 i 1894. Podała Marya Twardowska. Warszawa: [s. n.], 1896, s. 115-118 [nadb.: „Pamiętnik Fizjograficzny", t. 14 za rok 1896]. 
1897

Notatki florystyczne z powiatu mozyrskiego. Podała Marya ze Skirmutów Twardowska. Poznań: [s.n.], 1897 (Poznań: Drukarnia Dziennika Poznańskiego), ss. 27 [odb.: „Rocznik Towarzystwa Przyjaciół Nauk Poznańskiego”, t. 24].

\section{8}

Atlas historyi naturalnej: zoologia, botanika i mineralogia: $w 180$ obrazkach kolorowanych na 28 tablicach. Z tekstem Feliksa Wermińskiego. Warszawa: nakładem Księgarni Dubowskiego i Gajewskiego, 1898 (Warszawa: Drukarnia Towarzystwa Komandytowego St. J. Zaleski), ss. 16, k. tabl. 28.

Wiorogórski Władysław, Słownik nowych środków lekarskich. Podręcznik dla aptekarzy, lekarzy i materyalistów, Warszawa: [s.n.], 1898, ss. VIII, 1398, 23.

1900

Rostafiński Józef. Słownik polskich imion rodzajów oraz wyższych skupień roślin poprzedzony historyczna rozprawa o źródłach. Przez Józefa Rostafińskiego. Materyały do Historyi Języka i Dyalektologii Polskiej, t. 1. Kraków: Akademia Umiejętności, 1900, ss. IV, 834, [2].

[Rostafiński Józef], Średniowieczna historya naturalna. Systematyczne zestawienie roślin, zwierząt, minerałów oraz wszystkich innego rodzaju leków prostych, używanych $w$ Polsce od XII do XVI w. Cz. 1, = Symbola ad historiam naturalem medii aevi. Przez Józefa Rostafińskiego. Seria Munera Saecularia Universitatis Cracoviensis, vol. 3. Kraków: nakł. Uniwersytetu, 1900, ss. XXI, 605, k. [4] [indeksy].

[Rostafiński Józef], Średniowieczna historya naturalna. Systematyczne zestawienie roślin, zwierząt, minerałów oraz wszystkich innego rodzaju leków prostych, używanych $w$ Polsce od XII do XVI w. Cz. 2, = Symbola ad historiam naturalem medii aevi. Przez Józefa Rostafińskiego. Seria Munera Saecularia Universitatis Cracoviensis, vol. 8. Kraków: nakł. Uniwersytetu, 1900, ss. 352 [Cz. 2: Materyały źródłowe do słownictwa przyrodniczego średnich wieków $w$ Polsce].

Rostafiński Józef. Symbola ad historiam naturalem medii aevii. Plantas, animalia, lapides et cetera simplicia medicamenta quae in Polonia adhibebantur inde a XII usque ad XVI saeculum (quattuor cum tabulis). Ps 1 = Średniowieczna historya naturalna $w$ Polsce. Cz. 1, collegit, ad artis rationem redegit Józef Rostafiński. Munera Saecularia Universitatis Cracoviensis vol. 7. Cracoviae: sumpt. Universitatis, 1900, ss. XXI, 605 [indeksy].

Rostafiński Józef. Symbola ad historiam naturalem medii aevi. Plantas, animalia, lapides et cetera simplicia medicamenta quae in Polonia adhibebantur inde a XII usque ad XVI saeculum (quattuor cum tabulis). Ps 2, [Collectanea scientiam naturalem qualis medii aevi temporibus in Polonia viguit, collegit, ad artis rationem redegit Josephus Rostafiński]. Munera Saecularia Universitatis Cracoviensis vol. 8. Cracoviae: sumpt. Universitatis, 1900 ss. [4], 352, k. [4] [indeksy].

Słownik polskich imion rodzajów oraz wyższych skupień roślin poprzedzony historyczna rozprawa o źródłach. Przez Józefa Rostafińskiego. Materyały do Historyi Języka i Dyalektologii Polskiej, t. 1. Kraków: nakładem Akademii Umiejętności, 1900 (Kraków: Drukarnia C.K. UJ), ss. IV, 834, [2] [nazwy rodzajów roślin także łac.]. 
Wilkomm Maurycy. Atlas państwa roślinnego: zawierajacy 124 tablice kolorowane $z 700$ rysunkami roślin oraz 165 drzeworytów wśród tekstu szczegółowego oprac. przez Wł. M. Kozłowskiego. Warszawa: nakład i własność Michała Arcta, 1900, ss. II, [187], k. tabl. 124.

\section{1}

Przewodnik do oznaczania krajowych roślin nasiennych. Przez Józefa Rostafińskiego, ozdobione portretem K. Kluka rysunku P. Stachiewicza. Wyd. 2 pomnożone, uwzględniające wszystkie (...) rośliny. Kraków: nakł. autora, 1901 (Kraków: Drukarnia W.L. Anczyc i Spółka], ss. 109, [2], k. [1].

\section{2}

Świat roślin (botanika). Cz. 2. Oprac. Wacław Tański, seria Bezpłatne Dodatki „Ziarna”, 11. Warszawa: nakł. „Ziarna”, 1902 (Warszawa: Drukarnia A. T. Jezierskiego), ss. 199 [spis roślin].

\section{3}

[Burniewski D.] Бурневский Д. Параллельный ботачический словарь латинскопольско-русский, польско-латинско-русский и русско-латинско-польский. Ченстохов: Типография и литография Ф.Д. Вилькошевского, 1903, ss. [6], 73.

\section{4}

Prowincyonalne, polskie nazwy roślin XVIII w., z Prus Książęcych głównie z rękopisu Andrzeja Helwinga. Oprac. przez Józefa Rostafińskiego. Kraków: [s.n.], 1904, ss. [2], 30 [osobne odbicie z „Rozpraw Wydziału filologicznego Akademii Umiejętności w Krakowie", t. XL].

\section{6}

Przewodnik do oznaczania pospolitszych roślin. Z. 1-2, przez Józefa Rostafińskiego. Wyd. 3. Kraków: nakł. autora, 1906 (Kraków: Drukarnia W.L. Anczyc i Spółka], 2 t. w 1 wol. (ss. 140, [96]) [wyd. obejmujące około 900 dziko rosnących roślin z 376 rycinami; tyt. okł.: Przewodnik do oznaczania roślin z 376 miedziorytami].

\section{1}

Wilkomm Maurycy. Atlas państwa roślinnego: zawierajacy 125 tablic kolorowych $z 700$ rysunkami roślin oraz liczne drzeworyty wśród tekstu szczegółowego oprac. przez Wt. M. Kozłowskiego. Wyd. 2 przejrz. i uzup. Warszawa: Wydawnictwo M. Arcta, 1911, ss. 208, k. tabl. 125.

\section{3}

Wóycicki Z. Przyczynek do znajomości flory Wzgórz Kazimierskich. Wykaz niektórych wątrobowców i mchów, częściej występujących w Kazimierzu nad Wisła i jego okolicach, Warszawa: [s.n.], 1913 (Warszawa: Druk Rubiszewskiego i Wrotnowskiego), s. 980-983 [odbicie: „Sprawozdania z posiedzeń Towarzystwa Naukowego Warszawskiego. Wydział Nauk Matematycznych i Przyrodniczych", z. 9, 1913]. 


\section{4}

Słowniczek ludowych i naukowych nazw leków, surowców i przetworów chemicznych używanych $w$ Galicyi, Królestwie Polskiem $i$ w Ks. Poznańskiem. Ułożył Zdzisław Zawałkiewicz. Warszawa: nakł. J. Bielawskiego, 1914 (Warszawa: Drukarnia i Litografia Towarzystwo B. A. Bukaty), ss. VIII, 84, ss. tabl. 37 [współwyd.: Cennik Zakładów Graficznych T-wa B. A. Bukaty. Litografia, drukarnia, fabryka dekalkomanii i plakatów reklamowych].

Wiorogórski Władysław, Słownik nowych środków lekarskich. Podręcznik dla aptekarzy, lekarzy i materjalistów, Warszawa: [s.n.], 1914, ss. VIII, 1394.

\section{1}

Garbowski Ludwik. Choroby roślin. Powstawanie, objawy, zwalczanie. Seria Praktyczna Encyklopedja Gospodarstwa Wiejskiego, nr 5. Warszawa: Księgarnia Rolnicza, 1921 (Warszawa: Druk Synów St. Niemiry), ss. [8], 64.

Przewodnik do oznaczania roślin $w$ Polsce dziko rosnacych. Z 440 rycinami. Z. 1: Z tekstem, przez Józefa Rostafińskiego. Wyd. 5. Lwów: Zakład Narodowy im. Ossolińskich, 1921, ss. VIII, 151 [wyd. 5 obejmuje: Rodniowce i rośliny nasienne].

Przewodnik do oznaczania roślin w Polsce dziko rosnacych. Z 440 rycinami. Z. 2: Z rycinami, przez Józefa Rostafińskiego. Wyd. 5. Lwów: Zakład Narodowy im. Ossolińskich, 1921, ss. [56], rys. 440 [wyd. 5 obejmuje: Rodniowce i rośliny nasienne].

Zielnik Polski: miesięcznik ilustrowany, poświęcony ziołom leczniczym, higjenie i przyrodolecznictwu. Red. i wyd. Stanisław Breyer. Kraków: Stanisław Breyer, 1921-1922.

\section{3}

Hryniewiecki Bolesław. Przyczynek do znajomości flory ziemi Czukockiej = Contributions to the study of the flora in Tchuktchiland. Seria Archiwum Nauk Biologicznych Towarzystwa Naukowego Warszawskiego, t. 1, z. 18. Lwów - Warszawa: Książnica Polska Towarzystwa Nauczycieli Szkół Wyższych, 1923, ss. 35 [spisy roślin].

Nehring Edward. Cebula oraz rośliny pokrewne (uprawa, hodowla i sprzedaż). Seria Praktyczna Encyklopedja Gospodarstwa Wiejskiego, nr 46-47. Warszawa: nakł. Księgarni Rolniczej, 1923 ([Warszawa]: Druk Synów St. Niemiry), ss. 86, [2].

Przewodnik do oznaczania roślin $w$ Polsce dziko rosnących. Z. 1, przez Józefa Rostafińskiego. Wyd. 6 powiększ. Lwów: Zakład Narodowy im. Ossolińskich - Wydawnictwo, 1923, ss. VIII, 167 [wyd. 6 obejmuje: Rodniowce i rośliny nasienne].

Przewodnik do oznaczania roślin $w$ Polsce dziko rosnacych. Z 440 rycinami. Z. 2: Z rycinami, przez Józefa Rostafińskiego. Wyd. 6 powiększ. Lwów: Zakład Narodowy im. Ossolińskich, 1923, ss. [102] [wyd. 6 obejmuje: Rodniowce i rośliny nasienne].

Wykaz drzew godnych ochrony na Śląsu Górnym według Th. Schube „Waldbuch von Schlesien”. Zestawił Tadeusz Wiśniewski, wstępem opatrzył Bolesław Hryniewiecki. Seria Państwowa Komisja Ochrony Przyrody, nr 3. Kraków: Państwowa Komisja Ochrony Przyrody, 1923, ss. 12.

\section{4}

Strasburger Edward. Krótki przewodnik do zajęć praktycznych z botaniki mikroskopowej. Wyd. 2 według IX-go niem. wyd. przer. i uzup. Tadeusz Kołodziejczyk. War- 
szawa: Wydawnictwo M. Arcta, 1924, ss. VII, [1], 296 [spis badanych roślin, wykaz najniezbędniejszych odczynników i barwników, spis ogólny].

Szafer Władysław, Kulczyński Stanisław, Pawłowski Bogumił. Rośliny polskie. Opisy $i$ klucze do oznaczania wszystkich gatunków roślin naczyniowych rosnacych $w$ Polsce bądź dziko, bądź też zdziczalych lub częściej hodowanych dla użytku florystów, uczniów szkó wyższych i średnich, rolników, leśników, farmaceutów i innych miłośników przyrody. Lwów - Warszawa: Książnica - Atlas, 1924, ss. XXXII, 736.

\section{5}

Garbowski Ludwik. Choroby roślin rolniczych. Seria Encyklopedja Gospodarstwa Wiejskiego, nr 77-80. Warszawa: Księgarnia Rolnicza, 1925, ss. 271.

Mały atlas roślin górskich. Warszawa: Wydawnictwo M. Arcta, 1925, ss. 41, [1], k. tabl. złoż. [1].

Schreiber Joachim F. Mały atlas roślin leczniczych. Tł. Tadeusz Karyłowski. Warszawa: Wydawnictwo M. Arcta, 1925, ss. 15, [1], k. tabl. [12] [32 rys. kolor. na 12 tablicach z tekstem objaśniającym].

\section{6}

Wierdak Szymon. Wykaz drzew godnych ochrony. Lwów: Polskie Towarzystwo Dendrologiczne, 1926, ss. 17 [odb.: „Polskie Towarzystwo Dendrologiczne”, R. 1].

1927

Kulesza Witold. Wykaz drzew i krzewów godnych ochrony w poznańskiem i na Pomo$r z u$. Kraków: Państwowa Rada Ochrony Przyrody, 1927, ss. 37, k. tabl. [4] [odb.: „Ochrona Przyrody”, t. 7].

Słownictwo anatomiczno-botaniczne. Skrót wedlug projektu słownictwa prof. dr. Wł. Mazurkiewicza. Zebr. i ułożył Mieczysław Proner. Zakład Farmakognozji i Botaniki Lekarskiej Uniwersytetu Warszawskiego. Warszawa: nakł. Fr. Heroda, 1927 (Warszawa: Drukarnia Wzorowa), ss. 42, [1].

\section{8}

Catalogi plantarum quae A. 1651 Varsaviae in hortis botanicis regis Ioannis Casimiri colebantur, secundum conspectus hortulanorum Bartholomei Gei et Jacobi Haic: accedit catalogus tertius plantarum indigenarum, quae circa Varsaviam nascuntur, auctore Martino Bernhardo, edidit et ambo priores in systema naturale redegit Josephus Rostafiński = Królewskie ogrody botaniczne króla Jana Kazimierza $w$ Warszawie oraz systematyczny spis roślin tamże hodowanych. Wydał i oprac. Józef Rostafiński, Editionum Collegii ad Historiam Scientiarum Mathem.-Naturalium Perscrutandam, vol. 2. Cracoviae: Academiae Litterarum et Scientiarum Polonae apud Bibliopolam G. Gebethner et Wolff, 1928 (Kraków: Drukarnia Uniwersytetu Jagiellońskiego), ss. 100 [oryg. publikacja Martina Bernharda wyd. w 1652 r. w Gdańsku; dostępny również w formie elektronicznej].

Ćwiczenia $z$ anatomji roślin. 2: Atlas. Oprac. Adam Czartkowski. Wyd. 3, przejrzane. Warszawa: Wydawnictwo M. Arcta, 1928 (Warszawa: Drukarnia Zakładów Wydawniczych M. Arct), ss. [4], s. tabl. 31 [na s. tyt.: 102 rysunki na 31 tablicach]. 


\section{9}

Golonka Zygmunt. Zielnik roślin łąkowych. Skierniewice: Zakład Uprawy i Nawożenia Roli, 1929, ss. 24.

Siemaszko W., Kaznowski Lucjan. Choroby roślin uprawnych: zielnik. Z. 2: Choroby drzew i krzewów owocowych. Seria Bibljoteka Puławska, nr 7. Puławy: Państwowy Instytut Naukowy Gospodarstwa Wiejskiego, 1929, teka 21 k. tabl. złoż.

\section{0}

Kulczyński Stanisław, Atlas flory polskiej = (Florae polonicae iconographia). T. 3 z. 2: Cyperaceae - Caricoideae (pars 1). Tablice oprac. Józef Mądalski. Polska Akademja Umiejętności. Kraków: nakł. Polskiej Akademji Umiejętności, 1930 (Drukarnia Uniwersytetu Jagiellońskiego), teka (ss. IV, 21, k. tabl. luź. 41).

Zielnik czyli Atlas roślin lekarskich polecanych przez Sebastjana Kneippa. Tekst, zawierający opis roślin z podaniem zastosowań ich oprac. Dr. R. Wyd. 4. Monachjum: nakł. J. Kösela i F. Pusteta - Łódź: Michał Ettinger, 1930, ss. [6], 41, k. tabl. XX.

\section{1}

Grochowski Wacław. Flora Wilanowa i okolic, seria Bibljoteka „Wiadomości Farmaceutycznych”, t. 15. Warszawa: nakł. Fr. Heroda, 1931 (Warszawa: Drukarnia Wzorowa), ss. 61.

Kulczyński Stanisław. Atlas flory polskiej = (Florae polonicae iconographia). T. 2 z. 2: Juncaceae. Tablice oprac. Tadeusz Szynal i Józef Mądalski. Polska Akademja Umiejętności. Kraków: nakł. Polskiej Akademji Umiejętności, 1931 (Drukarnia Uniwersytetu Jagiellońskiego), teka (ss. 17, k. tabl. luź. 38).

Kulczyński Stanisław. Atlas flory polskiej = (Florae polonicae iconographia). T. 4 z. 1: Gramineae (pars 1). Tablice oprac. Karol Baecker i Jeremi Iwanicki. Polska Akademja Umiejętności, Kraków: nakł. Polskiej Akademji Umiejętności, 1931 (Drukarnia Uniwersytetu Jagiellońskiego), teka (ss. 16, k. tabl. luź. 29).

Tuz Stefan. Rośliny owadożerne Polski. Warszawa: Książnica - Lwów: Atlas, 1931 (Toruń: Pomorska Drukarnia Rolnicza), ss. 97, [7].

W.M. Słownik botaniczny angielsko-francusko-niemiecko-łacińsko-polski. Dla użytku ogrodników. Warszawa: Towarzystwo Pszczelno-Ogrodnicze, 1931, ss. 78.

\section{2}

Kulczyński Stanisław. Atlas flory polskiej = (Florae polonicae iconographia). T. 4 z. 2: Gramineae (pars 2). Tablice oprac. Karol Baecker i Jeremi Iwanicki. Polska Akademja Umiejętności. Kraków: nakł. Polskiej Akademji Umiejętności, 1932 (Drukarnia Uniwersytetu Jagiellońskiego), teka (ss. 16, k. tabl. luź. 31).

Spis roślin leczniczych $i$ przemysłowych rosnacych $i$ uprawianych $w$ Polsce $=$ Liste des plantes médicinales et industrielles croissant à lètat souvage on cultivées en Pologne = Verzeichnis der wildwachsenden sowie angebauten Heil- und Industrie-Pflanzen in Polen = Specification of medicinal and industrial plants growing in a wild state or being cultivated in Poland = Elenco di piante medicinali ed industriali silvestri e campestri, crescenti e coltivate in Polonia. Polski Komitet Zielarski. Warszawa: Polski Komitet Zielarski, 1932 (Warszawa: Drukarnia Nowoświecka), ss. 32. 


\section{3}

Pawe L. Słownik botaniczny polsko-łacińsko-hebrajski z alfabetycznemi spisami nazw łacińskich i hebrajskich. Warszawa: Stowarzyszenie Kulturalno Oświatowe „Tarbut”, 1933 (Warszawa: Grafika), ss. 130, XIII [zawiera nazwy polskie, łacińskie i hebrajskie wszystkich gatunków roślin naczyniowych rosnących w Polsce bądź dziko bądź też zdziczałych lub częściej hodowanych].

Wykaz zbóż ozimych, obejrzanych na pniu w r. 1934 przez Wydział Nasienny Sekcji Centralnej do Spraw Nasiennictwa przy Związu Izb i Organizacyj Rzplitej Polskiej. Warszawa: [s.n.], 1934, ss. 11, [1].

Wykaz zbóż ozimych, uznanych warunkowo na pniu przez Wielkopolską Izbę Rolnicza w 1933 roku. Poznań: [s.n.], 1933, k. [2].

\section{5}

Motyka Józef, Panycz T. Rośliny lecznicze i przemysłowe w Polsce. Opis, uprawa, zbiór, handel. Lwów: Książnica - Warszawa: Atlas, [ca 1935] (Lwów: Zakłady Graficzne), ss. $334+$ Atlas, ss. 46 [zawiera indeksy].

Przewodnik do oznaczania roślin $w$ Polsce dziko rosnacych. $Z 440$ rycinami. Z. 1: Z tekstem, przez Józefa Rostafińskiego. Wyd. 8. Lwów: Zakład Narodowy im. Ossolińskich, 1935, ss. VIII, 167 [wyd. 8 obejmuje: Rodniowce i rośliny nasienne].

Przewodnik do oznaczania roślin $w$ Polsce dziko rosnacych. Z. 2. Przez Józefa Rostafińskiego. Wyd. 9. Lwów: Zakład Narodowy im. Ossolińskich, 1935 (Kraków: W.L. Anczyc i Spółka), ss. [112] [wyd. 9. obejmuje Rodniowce i rośliny nasienne].

Wykaz zbóż jarych okopowych i innych jarych roślin, obejrzanych na pniu przez Wydziat Nasienny Sekcji Centralnej do Spraw Nasiennictwa przy Związku Izb i Organizacyj Rolniczych R. P. w Warszawie w r. 1934 na sezon wiosenny 1935. Warszawa: [s.n.], 1935, ss. 15, [1].

\section{6}

Kulczyński Stanisław. Atlas flory polskiej = (Florae polonicae iconographia). T. 4 z. 3: Gramineae (pars 3). Tablice oprac. Jeremi Iwanicki. Polska Akademja Umiejętności, Kraków: nakł. Polskiej Akademji Umiejętności, 1936 (Drukarnia Uniwersytetu Jagiellońskiego), teka (ss. 13, k. tabl. luź. 31).

Kulczyński Stanisław. Atlas flory polskiej = (Florae polonicae iconographia). T. 4 z. 4: Gramineae (pars 4). Tablice oprac. Jeremi Iwanicki. Polska Akademja Umiejętności, Kraków: nakł. Polskiej Akademji Umiejętności, 1936 (Drukarnia Uniwersytetu Jagiellońskiego), teka (ss. 11, k. tabl. luź. 28).

Sinicynówna Zinaida. Zespoły roślinne torfowiskpod Nieświeżem (=Associations végétales de tourbières des environs de Nieśwież). Prace Towarzystwa Przyjaciół Nauk w Wilnie. Wydział Nauk Matematycznych i Przyrodniczych, t. 10. Prace Zakładu Systematyki Roślin i Ogrodu Botanicznego Uniwersytetu St. Batorego w Wilnie. Wilno: Zakłady Graficzne „Znicz”, 1936, ss. 60, k. tabl. [1] [spisy].

Słownik botaniczny łacińsko-małoruski. Zebrał i ułożył w latach 1877-1932 Stefan Makowiecki. Prace Komisji Językowej PAU, nr 24. Kraków: nakł. PAU - Warszawa: Skład Główny w Księgarniach Gebethnera i Wolffa [etc.] 1936 (Kraków - Drukarnia UJ pod zarządem J. Filipowskiego), ss. XV, [1] [Wykaz źródeł (wraz ze skróta- 
mi), z których nazwy zostały zaczerpnięte, s. VII-XV] [tyt. grzb.: Małoruski słownik botaniczny].

Szulczewski Jerzy Wojciech. Wykaz wyrośli (zoocecidia), zebranych w okolicy Myszyńca na Kurpiach $=$ Verzeichnis der in der Umgegend von Myszyniec im Kurpenlande (nördl. Polen) gesammelten Zoocecidien. Napisał J. W. Szulczewski. „Sprawozdanie Komisji Fizjograficznej Polskiej Akademii Umiejętności” 1935, t. 70. Kraków: [s.n.], 1936, ss. 111-128.

Wykaz roślin trujących pochodzenia krajowego. Warszawa: Polski Komitet Zielarski, 1936, ss. 7 [odb.: „Wiadomości Zielarskie” 1936, nr 10 (42)].

\section{8}

Czarnowski August. Zielnik lekarski: zastosowanie, opis botaniczny i uprawa najwazniejszych polskich roślin lekarskich. Wyd. 3. Warszawa: Księgarnia J. Przeworskiego, 1938 (Warszawa: Zakł. Druk. F. Wyszyński i S-ka), ss. 255, [1], k. tabl. [18].

Drewnowski Artur. Słownik towaroznaczo-przemysłowy polsko-rosyjsko-francusko-niemiecko-angielski, a częściowo i łaciński (chemikalia i rośliny). Obejmuje: minerały, surowce, półfabrykaty, fabrykaty, metale, stopy, barwniki (...), wszystko z objaśnieniami i równoznacznikami w językach polskim i obcych. Z. 1. Wilno: nakładem autora, 1938, ss. 80.

Drewnowski Artur. Słownik towaroznaczo-przemysłowy polsko-rosyjsko-francusko-niemiecko-angielski, a czesściowo i łaciński (chemikalia i rośliny). Obejmuje: minerały, surowce, półfabrykaty, fabrykaty, metale, stopy, barwniki (...), wszystko z objaśnieniami i równoznacznikami w językach polskim i obcych. Z. 2. Wilno: nakładem autora, 1938, ss. 81-160.

Drewnowski Artur. Słownik towaroznaczo-przemysłowy polsko-rosyjsko-francusko-niemiecko-angielski, a częściowo i łaciński (chemikalia i rośliny). Obejmuje: minerały, surowce, półfabrykaty, fabrykaty, metale, stopy, barwniki (...), wszystko z objaśnieniami i równoznacznikami w językach polskim i obcych. Z. 3. Wilno: nakładem autora, 1938, ss. 161-240.

Drewnowski Artur. Słownik towaroznaczo-przemysłowy polsko-rosyjsko-francusko-niemiecko-angielski, a częściowo i łaciński (chemikalia i rośliny). Obejmuje: minerały, surowce, półfabrykaty, fabrykaty, metale, stopy, barwniki (...), wszystko z objaśnieniami i równoznacznikami w językach polskim i obcych. Z. 4. Wilno: nakładem autora, 1938, ss. 241-320.

Polskie mianownictwo botaniczne w zakresie cytologii i histologii roślin. Dział 2, Embriologia, Polskie Towarzystwo Botaniczne. Warszawa 1938, ss. 5 [nazwy polskie i łacińskie].

Przewodnik do oznaczania roślin w Polsce dziko rosnących. Z 440 rycinami. Z. 1: Z tekstem. Przez Józefa Rostafińskiego. Wyd. 13. Lwów: Zakład Narodowy im. Ossolińskich, 1935, ss. VIII, 167 [wyd. 13 obejmuje: Rodniowce i rośliny nasienne].

Przewodnik do oznaczania roślin w Polsce dziko rosnacych. Z. 2. Przez Józefa Rostafińskiego. Wyd. 11. Lwów: Zakład Narodowy im. Ossolińskich, 1938 (Kraków: W.L. Anczyc i Spółka), ss. [110] [wyd. 9. obejmuje Rodniowce i rośliny nasienne].

Przewodnik do oznaczania roślin w Polsce dziko rosnacych. Z. 2: Z rycinami. Przez Józefa Rostafińskiego. Wyd. 13. Lwów: Zakład Narodowy im. Ossolińskich, 1938 (Kra- 
ków: W.L. Anczyc i Spółka), ss. [2] [112] [wyd. 13 obejmuje Rodniowce i rośliny nasienne].

Słowniczek polsko-łaciński i łacińsko-polski najwięcej używanych ziół leczniczych. Warszawa: Apteka J. Gessnera, [1938], ss. 35.

1939

Czarnowski August. Zielnik lekarski: zastosowanie, opis botaniczny i uprawa najważniejszych polskich roślin lekarskich. Wyd. 4. Warszawa: Księgarnia J. Przeworskiego, 1939 (Warszawa: Zakł. Druk. F. Wyszyński i S-ka), ss. 255, [1], k. tabl. [18].

Drewnowski Artur. Słownik towaroznaczo-przemysłowy polsko-rosyjsko-francusko-niemiecko-angielski, a częściowo i łaciński (chemikalia i rośliny). Obejmuje: mineraty, surowce, pólfabrykaty, fabrykaty, metale, stopy, barwniki (...), wszystko z objaśnieniami i równoznacznikami w językach polskim i obcych. Z. 5. Wilno: nakł. aut., 1939, ss. 321-400 [wydanie nieukończone].

Przewodnik do oznaczania roślin $w$ Polsce dziko rosnacych. $Z 440$ rycinami. Z. 1: Z tekstem. Przez Józefa Rostafińskiego. Wyd. 14. Lwów: Zakład Narodowy im. Ossolińskich, 1939, ss. 167 [wyd. 14 obejmuje: Rodniowce i rośliny nasienne].

Przewodnik do oznaczania roślin w Polsce dziko rosnących. Z. 2: Z rycinami. Przez Józefa Rostafińskiego. Wyd. 14. Lwów: Zakład Narodowy im. Ossolińskich, 1939 (Kraków: W.L. Anczyc i Spółka), ss. [110] [wyd. 14 obejmuje Rodniowce i rośliny nasienne].

\section{6}

Turowska Irena. Skorowidz zielarski. Kraków: [s.n.], 1946 (Kraków: Drukarnia Uniwersytetu Jagiellońskiego), ss. 16 [odb.: „Przegląd Zielarski” 1946, nr 9-12].

\section{7}

Szaferowa Janina. Poznaj 100 roślin. Klucz do oznaczania 100 gatunków roślin kwiatowych dzikich $i$ hodowanych. Seria Ilustrowane Klucze do Oznaczania Roślin Biblioteka Przyrodnicza. Warszawa: Państwowe Zakłady Wydawnictw Szkolnych, 1947, ss. 66 [indeks nazw polskich i łacińskich].

Szafer Władysław. Flora plioceńska $z$ Krościenka n/Dunajcem = The Pliocene flora of Krościenko in Poland. T. 2: Czesść opisowa = Descriptive part. Seria Rozprawy Wydziału Matematyczno-Przyrodniczego, Polska Akademia Umiejętności, t. 72. Dz. B. 1946. (Seria III, t. 32), nr 2. Kraków: nakł. Polskiej Akademii Umiejętności, 1947 (Kraków: Drukarnia Uniwersytetu Jagiellońskiego), ss. 213, k. tabl. złoż. [29] s. z objaśn. oraz 15 tabl [Alfabetyczny spis nazw roślin, s. 206-213].

\section{8}

Karchowski Tadeusz. Słownik polskich roślin lekarskich wraz $z$ dodatkiem. Słownik skrótów nazwisk botaników. Poznań: Centrala Wydawnicza, 1948, ss. 170.

Wykaz zbóż i innych roślin jarych zakwalifikowanych na pniu przez Związek Samopomocy Chłopskiej, Oddział Wojewódzki. Wydział Rolniczy w Bydgoszczy w roku 1948. Bydgoszcz: Związek Samopomocy Chłopskiej. Oddział, 1948, ss. 43, [1]. 


\section{0}

Szaferowa Janina. Poznaj 100 roślin. Klucz do oznaczania 100 gatunków roślin kwiatowych dzikich i hodowanych. Seria Biblioteka Przyrodnicza. Wyd. 2. Warszawa: Państwowe Zakłady Wydawnictw Szkolnych, 1950, ss. 68 [indeks nazw polskich i łacińskich].

\section{1}

Dmitrijew A. Łąkarstwo. Przeł. Eugeniusz Osieczański. Warszawa: Państwowe Wydawnictwo Rolnicze i Leśne,1951, ss. 352 [Wykaz nazw rosyjskich, polskich i łacińskich roślin łąkowych, s. 338-349].

Szulczewski Jerzy Wojciech. Wykaz roślin naczyniowych $w$ Wielkopolsce dotąd stwierdzonych. Poznańskie Towarzystwo Przyjaciół Nauk. Wydział Matematyczno-Przyrodniczy. Prace Komisji Biologicznej - Poznańskie Towarzystwo Przyjaciół Nauk. Wydział Matematyczno-Przyrodniczy, t. 12, z. 6. Poznań: Poznańskie Towarzystwo Przyjaciół Nauk, 1951, ss. [2]. 128k. tabl. [1].

Żukowski Piotr. Botanika. Przeł. z ros. Stanisław Ehrlich i Tadeusz Różycki. Wyd. 3 przer. Warszawa: Państwowe Wydawnictwo Rolnicze i Leśne, 1951 [wykaz alfabetyczny łacińskich i polskich nazw roślin; indeksy].

\section{2}

Czarnocki Jerzy, Wroczyński Jarosław. Podstawy nasionoznawstwa i czyszczalnictwa. Czyszczenie nasion traw i motylkowych. Warszawa: Państwowe Wydawnictwo Rolnicze i Leśne, 1952, ss. 452 [wykaz łaccińskich nazw roślin].

\section{3}

Rostafiński Józef. Przewodnik do oznaczenia roślin $w$ Polsce dziko rosnących. Oprac. i uzup. Olga Seidl. Wyd. 15. Warszawa: Państwowe Wydawnictwo Rolnicze i Leśne, 1953, ss. 369, [1] [Przeznaczona jest dla uczniów techników rolniczych i leśnych, uczniów średnich szkół ogólnokształcacych, studentów]

Siuziew Pavel. Zielnik. Przewodnik do zbierania i suszenia roślin do zielnika i kompletowania zbiorów florystycznych. Tł. z ros. Tadeusz Różycki. Seria Biblioteczka Przyrodnicza. Warszawa: Państwowe Zakłady Wydawnictw Szkolnych, 1953, ss. 91.

Szafer Władysław, Kulczyński Stanisław, Pawłowski Bogumił. Rośliny polskie. Opisy $i$ klucze do oznaczania wszystkich gatunków roślin naczyniowych rosnących $w$ Polsce bądź dziko, bądź też zdziczałych lub częściej hodowanych. Warszawa: Państwowe Wydawnictwo Naukowe, 1953, ss. XXVIII, 1020.

\section{4}

Dąmbska Izabella, Karpiński Józef. Ramienice. Klucz do oznaczania gatunków krajowych. Warszawa: Państwowe Wydawnictwo Naukowe, 1954, ss. 128 [zawiera Skorowidz łacińskich nazw ramienic].

Fijałkowski Dominik, Wykaz rzadszych roślin Lubelszczyzny = Enumeratio plantarum rariorum Terrae Lublinensis. Kraków: Polskie Towarzystwo Botaniczne, 1954, ss. [1], 82-93, [3] [osobne odbicie: „Fragmenta Floristica et Geobotanica”. Ann. I, Pars 2]. 
Mądalski Józef. Atlas flory polskiej i ziem ościennych = Florae polonicae terrarumque adiacentium iconographia. T. 1, z. 1: Ophioglossaceae, Osmundaceae, Polypodiaceae (pars 1), Salviniaceae, Marsiliaceae, Equisetaceae, Lycopodiaceae, Selaginellaceae et Isoëtaceae. Tablice oprac. Tadeusz Szynal. Polska Akademia Nauk. WarszawaWrocław: Państwowe Wydawnictwo Naukowe, 1954, teka (ss. 16, k. tabl. luź. 37).

Mądalski Józef. Atlas flory polskiej i ziem ościennych = Florae polonicae terrarumque adiacentium iconographia. T. 1, z. 2: Polypodiaceae (pars 2), Salviniaceae, Marsiliaceae, Equisetaceae, Lycopodiaceae, Selaginellaceae et Isoëtaceae. Tablice oprac. Tadeusz Szynal. Polska Akademia Nauk. Warszawa-Wrocław: Państwowe Wydawnictwo Naukowe, 1954, teka (ss. 18, k. tabl. luź. 33).

\section{5}

Mądalski Józef. Atlas flory polskiej i ziem ościennych = Florae polonicae terrarumque adiacentium iconographia. T. 1, z. 3: Taxaceae, Pinaceae, Cupressaceae, Ephedraceae. Tablice oprac. Tadeusz Szynal. Polska Akademia Nauk, Warszawa-Wrocław: Państwowe Wydawnictwo Naukowe, 1955, teka (ss. 17, k. tabl. luź. 20).

Mądalski Józef, Atlas flory polskiej i ziem ościennych = Florae polonicae terrarumque adiacentium iconographia. T. 9, z. 1: Papaveraceae. Tablice oprac. Franciszek Białous. Polska Akademia Nauk. Warszawa-Wrocław: Państwowe Wydawnictwo Naukowe, 1955, teka (ss. 13, k. tabl. luź. 22).

Nowaczyk Cz. Zielnik mchów Doświadczalnego Nadleśnictwa Zielonka pod Poznaniem. Poznań: Zakład Botaniki Leśnej Wyższej Szkoły Rolniczej, 1955, ss. [2], 15, [1].

\section{6}

Koczwara Marian. Farmakognozja. T. 3: Atlas roślin i surowców leczniczych. Akademia Medyczna w Krakowie. Kraków: Akademia Medyczna, 1956, ss. 369.

Rostafiński Józef. Przewodnik do oznaczenia roślin. Oprac. i uzup. Olga Seidl. Wyd. 16. Warszawa: Państwowe Wydawnictwo Rolnicze i Leśne, 1953, ss. [391]

\section{7}

Mchy (Musci). T. 1. Oprac. Bronisław Szafran, Polska Akademia Nauk, Instytut Botaniki. Seria Flora Polska. Rośliny Zarodnikowe Polski i Ziem Ościennych. Warszawa: Państwowe Wydawnictwo Naukowe, 1957, ss. 448, [3] [Skorowidz systematycznych nazw łacińskich].

Pawłowski Bogumił. Słowniczek botaniczny. Fachowe wyrazy używane w opisach roślin naczyniowych i kluczach do ich oznaczania. Warszawa: Państwowe Wydawnictwo Naukowe, 1957, ss. 40, [2].

Zielińska Regina. Polskie i łacińskie nazwy krajowych roślin leczniczych. Warszawa: Państwowe Zakłady Wydawnictw Lekarskich, 1957, ss. 60, [3].

\section{8}

Lisowski Stanisław. Wykaz gatunków mchów wydanych w Bryotheca Polonica (fasc. I-XLI) [= Index specierum muscorum quae in Bryotheca Polonica (fasc. I-XLI) editae sunt]. Poznań: Wydawnictwo PAN, 1958, ss. 35, [1]. 


\section{9}

Mądalski Józef. Atlas flory polskiej i ziem ościennych = Florae polonicae terrarumque adiacentium iconographia. T. 6, z. 1: Betulaceae, Fagaceae, Myricaceae, Juglandaceae. Tablice oprac. Adam Nowotarski i Józef Mądalski. Polska Akademia Nauk, Instytut Botaniki. Warszawa-Wrocław: Państwowe Wydawnictwo Naukowe, 1959, teka (ss. 22, k. tabl. luź. 22).

Podbielkowski Zbigniew. Rośliny torfowisk: [atlas]. Tabl. wykonała z natury Hanna Rembertowicz-Szymborska. Warszawa: Państwowe Zakłady Wydawnictw Szkolnych, 1959, ss. 182, [2].

Szweykowski Jerzy. Wykaz gatunków wątrobowców wydanych w Hepaticotheca Polonica $($ fasc. 1-10) = Index specierum hepaticarum, quae in Hepathicotheca Polonica (fasc. 1-10) editae sunt. Poznań: Wydawnictwo PAN, 1959, ss. 14, [1].

Tobolewski Zygmunt. Wykaz gatunków porostów wydanych $w$ Lichenotheca Polonica (fasc. I-X) [= Index specierum lichenum quae in Lichenotheca Polonica (fasc. I-X)]. Poznań: Wydawnictwo PAN, 1959, ss. 18.

Traczyk Tadeusz. Rośliny lasu liściastego: [atlas]. Warszawa: Państwowe Zakłady Wydawnictw Szkolnych, 1959, ss. 158, [1].

\section{0}

Gayówna Delfina. Rośliny łąk: [atlas]. Warszawa: Państwowe Zakłady Wydawnictw Szkolnych, 1960, ss. 165.

Rośliny ruderalne. Cz. 2 = Plantae ruderales. P. 2. Oprac. Krzysztof Rostański. Seria Zielnik roślin naczyniowych Śląska, fasc. 18, nr 426-450. Wrocław: Wydawnictwo Polskiej Akademii Nauk, 1960, ss. 7.

Schwarz Zofia, Szober Janina. Rośliny towarzyszące człowiekowi, Warszawa: Państwowe Zakłady Wydawnictw Szkolnych, 1960, ss. 113 [na okł. dod. do tyt.: Atlas].

\section{1}

Dąbrowski Wawrzyniec. Słownik nazw roślin łąkowo-pastwiskowych w układzie alfabetycznym: łacinski, polski, rosyjski, niemiecki, angielski, francuski, czeski. Instytut Melioracji i Użytków Zielonych. Biblioteczka „Wiadomości IMUZ” nr 4. Warszawa: Państwowe Wydawnictwo Rolnicze i Leśne, 1961, ss. 205.

Deryng Jakub, przy współpr. Bogusławy Dobrowolskiej, Janiny Kamińskiej i Ewy Walewskiej. Atlas sproszkowanych roślinnych surowców leczniczych. Warszawa: Państwowy Zakład Wydawnictw Lekarskich, 1961, ss. 378, [1].

Kostyniuk Mikołaj, Marczek Edward. Nasze rośliny chronione, Wrocławskie Towarzystwo Naukowe. Wrocław: Państwowe Wydawnictwo Naukowe, 1961, ss. 202 [Do bibliotek nauczycielskich $w$ szkołach podstawowych i licealnych oraz do bibliotek zakładów kształcenia nauczycieli] [zawiera Skorowidz nazw roślin łacińskich; indeksy].

Mchy (Musci). T. 2. Oprac. Bronisław Szafran. Polska Akademia Nauk. Instytut Botaniki. Seria Flora Polska. Rośliny Zarodnikowe Polski i Ziem Ościennych. Warszawa: Państwowe Wydawnictwo Naukowe, 1961, ss. 405, [3] [zawiera Skorowidz systematycznych nazw łacińskich; indeks]. 
Polakowska Maria. Rośliny wodne: [atlas]. Warszawa: Państwowe Zakłady Wydawnictw Szkolnych, 1961, ss. 121, [2].

Teofrast. Badania nad roślinami. Oprac. i tłum. z jęz. grec. Jerzy Schnayder. PAN, Oddział w Krakowie. Kraków 1961, ss. 386 [zawiera Indeks polsko-łacińsko-grecki oraz Indeks łacińsko-polski]

\section{2}

Dąbrowski Wawrzyniec. Słownik nazw roślin łąkowo-pastwiskowych w układzie alfabetycznym: łaciński, polski, rosyjski, niemiecki, angielski, francuski, czeski. Instytut Melioracji i Użytków Zielonych. Biblioteczka „Wiadomości IMUZ” nr 6. Wyd. 2. Warszawa: Państwowe Wydawnictwo Rolnicze i Leśne, 1962, ss. 205.

Encyklopedia ochrony roślin. Praca zbiorowa pod red. St. Gałeckiego et al. Aut. Jerzy Achremowcz et al. Warszawa: Państwowe Wydawnictwo Rolnicze i Leśne, 1963, ss. 933.

Karpowiczowa Ludmiła. Wykaz drzew i krzewów Ogrodu Botanicznego Uniwersytetu Warszawskiego. Warszawa: Państwowe Wydawnictwo Naukowe, 1962, ss. 170, [2]. Laskowska Wanda. Rośliny borów: [atlas]. Tabl. wykonała z natury Hanna Rembertowicz-Szymborska. Warszawa: Państwowe Zakłady Wydawnictw Szkolnych, 1962, ss. $145,[2]$.

Massalski Edmund. Obrazy roślinności krainy Gór Świętokrzyskich. Pamiętnik poszukiwań florystycznych Kazimierza Kaznowskiego. Fot. Edmund i Andrzej Massalscy. Kieleckie Towarzystwo Naukowe. Komisja Nauk Ścisłych. Kraków: Wydawnictwo Artystyczno-Graficzne, 1962, ss. 119, [1], ss. tabl. [80].

Podbielkowski Zbigniew. Rośliny wydm: [atlas]. Warszawa: Państwowe Zakłady Wydawnictw Szkolnych, 1962, ss. 126, [2].

Porosty (Lichenes). T. 5. Cz. 2. Oprac. Józef Motyka. Rys. oprac. K. Karczmarz i St. Matuszewska. Polska Akademia Nauk. Instytut Botaniki. Seria Flora Polska. Rośliny Zarodnikowe Polski i Ziem Ościennych. Porosty (Lichenes), t. 5, cz. 2. Warszawa: Państwowe Wydawnictwo Naukowe, 1962, ss. 353, [3] [zawiera Skorowidz systematycznych nazw łacińskich; indeks].

Rostafiński Józef, Seidl Olga. Przewodnik do oznaczenia roślin. Wyd. 17. Warszawa: Państwowe Wydawnictwo Rolnicze i Leśne, 1962, ss. 437, [1] [zawieta indeksy]

Wątrobowce (Hepaticae). Liverworts (Hepaticae), z. 1. Red. Zygmunt Czubiński i Jerzy Szweykowski. Oprac. Jerzy Szweykowski. Poznańskie Towarzystwo Przyjaciół Nauk, Wydział Matematyczno-Przyrodniczy, Komisja Biologiczna. Seria Atlas rozmieszczenia roślin zarodnikowych $\mathrm{w}$ Polsce $=$ Atlas of Geographical Distribution of Spore-plants in Poland, Ser. 4. Poznań: Państwowe Wydawnictwo Naukowe, 1962, teka (ss. 25, k. [10]) [tekst równoległy polski, angielski].

Włodarczyk Stanisław. Botanika łąkarska, [Podręcznik dla techników rolniczych o specjalności łąkarskiej]. Wyd. 2 popr. i uzup. Warszawa: Państwowe Wydawnictwo Rolnicze i Leśne, 1962, ss. 250, [6], [zawiera Skorowidz polsko-łaciński i łacińsko-polski nazw roślin]. 


\section{4}

Celiński Florian. Rośliny naczyniowe Puszczy Bukowej pod Szczecinem. Seria Prace Komisji Biologicznej. Poznańskie Towarzystwo Przyjaciół Nauk. Wydział Matematyczno-Przyrodniczy, t. 29, z. 2. Poznań: Państwowe Wydawnictwo Naukowe - Oddział, 1964, ss. 189, [1], k. złoz. [1] [zaweiar Skorowidz nazw systematycznych w języku łacińskim; indeks].

Nowiński Marian. Chwasty segetalne wyspy Wolin. Seria Prace Komisji Biologicznej, Poznańskie Towarzystwo Przyjaciół Nauk. Wydział Matematyczno-Przyrodniczy, t. 22, z. 6. Poznań: Poznańskie Towarzystwo Przyjaciół Nauk, 1964, ss. 38, [1], s. tabl. [2] [zawiera Skorowidz nazw systematycznych w języku łacińskim].

Porosty (Lichenes). T. 3, cz. 2. Oprac. Józef Motyka. Rys. oprac. St. Matuszewska, Polska Akademia Nauk. Instytut Botaniki. Seria Flora Polska. Rośliny Zarodnikowe Polski i Ziem Ościennych. Porosty (Lichenes), t. 3, cz. 2. Warszawa: Państwowe Wydawnictwo Naukowe, 1964, ss. 500, [2] [zawiera Skorowidz systematycznych nazw łacińskich; indeks].

Porosty (Lichenes). T. 4, cz. 2. Oprac. Józef Motyka. Rys. oprac. St. Matuszewska. Polska Akademia Nauk. Instytut Botaniki. Seria Flora Polska. Rośliny Zarodnikowe Polski i Ziem Ościennych. Porosty (Lichenes). t. 4, cz. 2. Warszawa: Państwowe Wydawnictwo Naukowe, 1964, ss. 414, [2] [zawiera Skorowidz systematycznych nazw łacińskich; indeks].

Podbielkowski Zbigniew. Słownik roślin użytkowych: polski, łaciński, angielski, francuski, niemiecki, rosyjski. Warszawa: Państwowe Wydawnictwo Rolnicze i Leśne, 1964, ss. 409.

Siemińska Jadwiga, Chrysophyta. 2: Bacillariophyceae - Okrzemki. Seria Flora Słodkowodna Polski. Red. Karol Starmach, t. 6. Warszawa: Państwowe Wydawnictwo Naukowe, 1964, ss. 609, [2] [zawiera Skorowidz nazw łacińskich; indeksy].

Turowska Irena. Rośliny nasienne: przegląd systematyczny ze szczególnym uwzględnieniem gatunków leczniczych $i$ użytkowych $z$ dodatkiem materiałów ćwiczeniowych $i$ atlasu roślin. Il. Zofia Brunarska. Akademia Medyczna w Krakowie. Kraków: Akademia Medyczna im. M. Kopernika, 1964, ss. 228, + Atlas, ss. 64 [dokument towarzyszący: Irena Turowska, Atlas do skryptu pt. Rośliny nasienne, il. Zofia Brunarska].

Wątrobowce (Hepaticae). Liverworts (Hepaticae). Z. 2, Red. Zygmunt Czubiński i Jerzy Szweykowski. Oprac. Jerzy Szweykowski. Poznańskie Towarzystwo Przyjaciół Nauk, Wydział Matematyczno-Przyrodniczy, Komisja Biologiczna. Seria Atlas rozmieszczenia roślin zarodnikowych w Polsce $=$ Atlas of Geographical Distribution of Spore-plants in Poland, Ser. 4. Poznań: Państwowe Wydawnictwo Naukowe, Oddział, 1964, teka (ss. 23, k. [10]) [tekst równoległy polski i przekład angielski].

Włodarczyk Stanisław. Botanika łąkarska, [Podręcznik dla techników rolniczych o specjalności łąkarskiej]. Wyd. 2 popr. i uzup. Warszawa: Państwowe Wydawnictwo Rolnicze i Leśne, 1964, ss. 238, [2], [4] [zawiera Skorowidz polsko-łaciński i łacińsko-polski nazw roślin] 


\section{5}

Gayówna Delfina. Rośliny łąk: [atlas]. Tabl. wykonała Ewa Śliwińska. Rys. kreskowe wykonała Hanna Rembertowicz-Szymborska. Wyd. 2. Warszawa: Państwowe Zakłady Wydawnictw Szkolnych, 1965, ss. 165, [2].

Podbielkowski Zbigniew. Rośliny torfowisk: [atlas]. Tabl. wykonała z natury Hanna Rembertowicz-Szymborska. Wyd. 2. Warszawa: Państwowe Zakłady Wydawnictw Szkolnych, 1965, ss. 182, [2].

Rostafiński Józef, Seidl Olga. Przewodnik do oznaczenia roślin. Wyd. 18 popr. i uzup. Warszawa: Państwowe Wydawnictwo Rolnicze i Leśne, 1962, ss. 441, [1] [indeksy] Traczyk Tadeusz. Rośliny lasu liściastego: [atlas]. Wyd. 2. Warszawa: Państwowe Zakłady Wydawnictw Szkolnych, 1965, ss. 157.

\section{6}

Międzynarodowy Kodeks Nomenklatury Botanicznej 1961 = International code of botanical nomenclature. Adopted by The Ninth International Botanical Congress, Montreal, August 1959. Prep. and ed. by J. Lanjouw et al. Tłum. S. Domański, J. Mądalski, A. Skirgiełło, Red. ogólna A. Skirgiełło. Warszawa: Państwowe Wydawnictwo Naukowe, 1966, ss. 250, [1] [tekst częśc. łac.; indeks]

Podbielkowski Zbigniew. Słownik roślin użytkowych: polski, łaciński, angielski, francuski, niemiecki, rosyjski. Rys. L. Brzywczy. Wyd. 2 popr. i uzup. Warszawa: Państwowe Wydawnictwo Rolnicze i Leśne, 1966, ss. 487, [1]

Rośliny użytkowe. Red. nauk. Tadeusz Gorczyński. Noty encyklopedyczne napisali Ludmiła Hausbrandt et al. Seria Wydawnictwa Popularno-Encyklopedyczne. Wyd. 2. Warszawa: Wiedza Powszechna, 1966, ss. 319, [1], ss. tabl. [4].

Wątrobowce (Hepaticae). T. 1. Oprac. Irena Rejment-Grochowska. Polska Akademia Nauk. Instytut Botaniki. Seria Flora Polska. Rośliny Zarodnikowe Polski i Ziem Ościennych. Warszawa: Państwowe Wydawnictwo Naukowe, 1966, ss. 257, [2] [zawiera Skorowidz systematycznych nazw łacińskich; indeks].

Wątrobowce (Hepaticae). Liverworts (Hepaticae). Z. 3. Red. Zygmunt Czubiński i Jerzy Szweykowski. Oprac. Jerzy Szweykowski. Poznańskie Towarzystwo Przyjaciół Nauk, Wydział Matematyczno-Przyrodniczy, Komisja Biologiczna. Seria Atlas rozmieszczenia roślin zarodnikowych w Polsce $=$ Atlas of Geographical Distribution of Spore-plants in Poland. Ser. 4. Poznań: Państwowe Wydawnictwo Naukowe, Oddział, 1966, teka (ss. 31, k. [10]) [tekst równoległy polski i przekład angielski].

\section{7}

Iwanowski Czesław, Łuczak Zenon, Mikstacki Bronisław. Przeglad wielkopolskich zabytków przyrody. Poznań: Redakcja Poradnika Gospodarskiego - Warszawa: Państwowe Wydawnictwo Rolnicze i Leśne, druk 1967, ss. 424, [4], s. tabl. [2] [spisy].

Szafer Władysław, Kulczyński Stanisław, Pawłowski Bogumił. Rośliny polskie. Opisy $i$ klucze do oznaczania wszystkich gatunków roślin naczyniowych rosnacych $w$ Polsce bądź dziko, bądź też zdziczałych lub częściej hodowanych. Wyd. 2. Warszawa: Państwowe Wydawnictwo Naukowe, 1967, ss. XXVIII, 1020 [indeksy].

Wątrobowce (Hepaticae). Liverworts (Hepaticae). Z. 4. Red. Zygmunt Czubiński i Jerzy Szweykowski. Oprac. Jerzy Szweykowski. Poznańskie Towarzystwo Przyjaciół 
Nauk, Wydział Matematyczno-Przyrodniczy, Komisja Biologiczna. Seria Atlas rozmieszczenia roślin zarodnikowych $\mathrm{w}$ Polsce $=$ Atlas of Geographical Distribution of Spore-plants in Poland. Ser. 4. Poznań: Państwowe Wydawnictwo Naukowe. Oddział, 1967, teka (ss. 31, k. [10]) [tekst równoległy polski i przekład angielski].

\section{8}

Atlas chorób i szkodników roślin oleistych. Kierownicy zespołu aut. i red. nauk. Jaroslav Benada, Josef Šedivý, Jan Špaček. Specjaliści konsultanci i aut. tekstu František Mráz, Josef Šedivý, František Kodys. Tłum. i uzup. tekstu Hanna Zarzycka (choroby), Eugeniusz Kamiński (szkodniki). Praga: Państwowe Wydawnictwo Rolnicze - Warszawa: we współpr. z Państwowym Wydawnictwem Rolniczym i Leśnym, 1968, teka (ss. [2], k. 56).

Mądalski Józef. Atlas flory polskiej i ziem ościennych = Florae polonicae terrarumque adiacentium iconographia. T. 3, z. 3: Cyperaceae - Caricoideae (pars 2). Tablice oprac. Tadeusz Kowal i Józef Mądalski. Tekst łaciński w tłum. J. Mądalskiego i E. Jacaka. Polska Akademia Nauk. Instytut Botaniki. Warszawa-Wrocław: Państwowe Wydawnictwo Naukowe, 1968, teka (ss. 65, k. tabl. luź. 35).

Wątrobowce (Hepaticae). Liverworts (Hepaticae). Z. 5. Red. Zygmunt Czubiński i Jerzy Szweykowski. Oprac. Jerzy Szweykowski. Poznańskie Towarzystwo Przyjaciół Nauk, Wydział Matematyczno-Przyrodniczy, Komisja Biologiczna. Seria Atlas rozmieszczenia roślin zarodnikowych $\mathrm{w}$ Polsce $=$ Atlas of Geographical Distribution of Spore-plants in Poland, Ser. 4. Poznań: Państwowe Wydawnictwo Naukowe. Oddział, 1968, teka (ss. 29, [2], k. [10]) [tekst równoległy polski i przekład angielski].

Wykaz gruntowych roślin zielnych i roślin szklarniowych. Oprac. zbiorowe pod red. Ludmiły Karpowiczowej. Oprac. Janina Andrearczyk et al. Hortus botanicus Universitatis Varsaviensis. Warszawa: Państwowe Wydawnictwo Naukowe, 1968, ss. 89, [2], s. tabl. 2 .

\section{9}

Leksykon haseł hodowli roślin i nasiennictwa oraz nauk pokrewnych. Kom. red. leksykonu J. Lekczyńska et al. Aut. W. Bejnar et al. Seria Biuletyn Instytutu Hodowli i Aklimatyzacji Roślin, nr 1-2 (88-89) 1969. Warszawa: Instytut Hodowli i Aklimatyzacji Roślin, 1969, ss. 156, [1] [hasła i indeksy także w językach: rosyjskim, angielskim, niemieckim].

Podbielkowski Zbigniew. Rośliny torfowisk: [atlas]. Tabl. wykonała z natury Hanna Rembertowicz-Szymborska. Wyd. 3. Warszawa: Państwowe Zakłady Wydawnictw Szkolnych, 1969, ss. 182, [2].

Polakowska Maria. Rośliny wodne: [atlas]. Wyd. 3. Warszawa: Państwowe Zakłady Wydawnictw Szkolnych, 1969, ss. 121, [2].

Schwarz Zofia, Szober Janina. Rośliny towarzyszace człowiekowi. Wyd. 3. Warszawa: Państwowe Zakłady Wydawnictw Szkolnych, 1969, ss. 113, [3].

Szafer Władysław, Kulczyński Stanisław, Pawłowski Bogumił. Rośliny polskie. Opisy i klucze do oznaczania wszystkich gatunków roślin naczyniowych rosnacych $w$ Polsce bądź dziko, bądź też zdziczałych lub częściej hodowanych. Wyd. 3. Warszawa: Państwowe Wydawnictwo Naukowe, 1969, ss. XXVIII, 1020 [indeksy]. 
Traczyk Tadeusz. Rośliny lasu liściastego: [atlas]. Wyd. 3. Warszawa: Państwowe Zakłady Wydawnictw Szkolnych, 1969, ss. 157, [2].

Turowska Irena. Rośliny nasienne: przegląd systematyczny ze szczególnym uwzględnieniem gatunków leczniczych $i$ użytkowych $z$ dodatkiem materiałów ćwiczeniowych $i$ atlasu roślin. Współpr. Elżbieta Cyunel. Atlas il. Zofia Brunarska. Wyd. 2. przejrz. i uzup. Kraków: Akademia Medyczna, 1969, ss. 242 + Atlas, ss. 64.

Wątrobowce (Hepaticae). Liverworts (Hepaticae). Z. 6. Red. Jerzy Szweykowski i Teofil Wojterski. Oprac. Jerzy Szweykowski. Poznańskie Towarzystwo Przyjaciół Nauk, Wydział Matematyczno-Przyrodniczy, Komisja Biologiczna. Seria Atlas rozmieszczenia roślin zarodnikowych w Polsce = Atlas of Geographical Distribution of Spore-plants in Poland, Ser. 4. Poznań: Państwowe Wydawnictwo Naukowe, Oddział, 1969, teka (ss. 24, k. [10]) [tekst równoległy polski i przekład angielski].

\section{0}

Koczwara Marian. Farmakognozja, t. 3: Atlas roślin i surowców leczniczych. Akademia Medyczna w Krakowie. Wyd. 3. Kraków: Akademia Medyczna, 1970, ss. 369.

\section{1}

Fabiszewski Jerzy. Rośliny Sudetów: atlas. Tablice wykonał Władysław Micek. Warszawa: Państwowe Zakłady Wydawnictw Szkolnych, 1971, ss. 157, [3].

Gayówna Delfina. Rośliny łąk: [atlas]. Wyd. 3. Warszawa: Państwowe Zakłady Wydawnictw Szkolnych, 1971, ss. 165, [1], k. tabl. 60.

Izdebski Krystyn, Grądziel Tadeusz. Roztocze. Seria Przyroda Polska. Warszawa: Wiedza Powszechna, 1971, ss. 190, [1], s. fot. [70] [zawiera Skorowidz nazw roślin i zwierząt].

Mądalski Józef. Atlas flory polskiej i ziem ościennych = Florae polonicae terrarumque adiacentium iconographia. T. 5, z. 1: Orchidaceae (pars 1). Tablice oprac. Jadwiga Mikulska i Józef Mądalski, Tekst łaciński w tłum. J. Mądalskiego i E. Jacaka. Polska Akademia Nauk. Instytut Botaniki. Warszawa-Wrocław: Państwowe Wydawnictwo Naukowe, 1971, teka (ss. 63, k. tabl. luź. 32).

Mchy Pomorza Zachodniego = Musci Pomeraniae Occidentalis. Oprac. Stanisław Balcerkiewicz i Piotr Szmajda. Seria Zielnik Mchów Polski = Bryotheca Polonica, fasc. 73, nr 1851-1875. Poznań: Wydawnictwo Polskiej Akademii Nauk, 1971, ss. 8.

Porosty (Lichenes). Z. 1. Red. Jerzy Szweykowski i Teofil Wojterski. Oprac. Jerzy Szweykowski. Oprac. Zygmunt Tobolewski. Komitet Botaniczny PAN i Poznańskie Towarzystwo Przyjaciół Nauk, Wydział Matematyczno-Przyrodniczy, Komisja Biologiczna. Seria Atlas rozmieszczenia roślin zarodnikowych w Polsce $=$ Atlas of Geographical Distribution of Spore-plants in Poland, Ser. 3. Poznań: Państwowe Wydawnictwo Naukowe, 1971, teka (ss. 31, k. [10]) [tekst równoległy polski i przekład angielski].

Rejment Grochowska Irena. Bryophyta 2, Hepaticae - Wątrobowce. Polska Akademia Nauk. Instytut Botaniki. Seria Flora Słodkowodna Polski, t. 17. Kraków: Państwowe Wydawnictwo Naukowe, 1971, ss. 334, [2] [zawiera Skorowidz nazw łacińskich; indeks]. 
Rutkowska Barbara. Atlas roślin łąkowych i pastwiskowych: 150 gatunków. Tablice barwne wykonała z natury Hanna Rembertowicz-Szymborska. Warszawa: Państwowe Wydawnictwa Rolnicze i Leśne, 1971, ss. 336.

Turowska Irena, Podbielkowski Zbigniew, Wojewoda Władysław. Rośliny zarodnikowe. Atlas il. Zofia Brunarska. Kraków: Akademia Medyczna, 1971, ss. $195+$ Atlas, ss. 51.

Wątrobowce (Hepaticae). Liverworts (Hepaticae). Z. 7. Red. Jerzy Szweykowski i Teofil Wojterski. Oprac. Jerzy Szweykowski. Komitet Botaniczny PAN i Poznańskie Towarzystwo Przyjaciół Nauk, Wydział Matematyczno-Przyrodniczy, Komisja Biologiczna. Seria Atlas rozmieszczenia roślin zarodnikowych w Polsce $=$ Atlas of Geographical Distribution of Spore-plants in Poland, Ser. 4. Poznań: Państwowe Wydawnictwo Naukowe. Oddział, 1971, teka (ss. 22, k. [10]) [tekst równoległy polski i przekład angielski].

Włodarczyk Stanisław. Botanika łąkarska, [Podręcznik dla techników rolniczych o specjalności łąkarskiej]. Wyd. 3. Warszawa: Państwowe Wydawnictwo Rolnicze i Leśne, 1971, ss. 240, [4] [zawiera Skorowidz polsko-łaciński i łacińsko-polski nazw roślin].

\section{2}

Kadłubowska Joanna Zofia. Chlorophyta. 5: Conjugales: Zygnemaceae Zrostmicowate. Seria Flora Słodkowodna Polski, t. 12 A. Kraków: Państwowe Wydawnictwo Naukowe, 1972, ss. 430, [4], s. tabl. [21] [zawiera Skorowidz nazw łacińskich; Indeks]. Karpiński jan Jerzy. Puszcza Białowieska. Red. Stefan Graniczny. Seria Przyroda Polska. Wyd. 2 uzup. Warszawa: Wiedza Powszechna, 1972, ss. 146, s. fot. [56], s. tabl. [2] [zawiera Skorowidz nazw roślin i zwierząt].

Karpowiczowa Ludmiła. Wykaz drzew i krzewów Ogrodu Botanicznego Uniwersytetu Warszawskiego. Wyd. 2 popr. i uzup. Warszawa: Państwowe Wydawnictwo Naukowe, 1972, ss. 171, [4], mapa.

Kępczyński Klemens, Ceynowa-Giełdon Mirosława. Obserwacje nad roślinnościa Zalewu Koronowskiego = Beobachtungen über die Vegetation des Stausees von Koronowo. Seria Studia Societatis Scientiarum Torunensis Toruń - Polonia. Sectio D (Botanica), vol. 9, nr 4. Warszawa-Poznań: Państwowe Wydawnictwo Naukowe, 1972, ss. 68, [1], k. tabl. złoż. [5] [spisy].

Novák František A. Wielki atlas roślin. Przeł. Aleksander Ostrowski. Warszawa: Państwowe Wydawnictwa Rolnicze i Leśne, 1972, ss. 588, [3], s. fot. [32].

Ringer Zofia. Rośliny Bałtyku: [atlas]. Tabl. wykonała Hanna Rembertowicz-Szymborska. Warszawa: Państwowe Zakłady Wydawnictw Szkolnych, 1972, ss. 149, [3].

Rostafiński Józef, Seidl Olga. Przewodnik do oznaczenia roślin. Wyd. 19. Warszawa: Państwowe Wydawnictwo Rolnicze i Leśne, 1972, ss. 441, [1] [indeksy].

Słownik nazw roślin pochodzenia obcego łacińsko-polski i polsko-łaciński. Red. Ludmiła Karpowiczowa. Uniwersytet Warszawski, Ogród Botaniczny. Warszawa: Wydawnictwa Uniwersytetu Warszawskiego, 1972, ss. 313, [1].

Starmach Karol. Chlorophyta, 3: Zielenice nitkowate: Ulothrichales, Ulvales, Prasiolales, Sphaeropleales, Cladophorales, Chaetophorales, Trentepohliales, Siphonales, Dichotomosiphonales (With Keys for the Identification of Filamentous Green Algae Mentioned in the Volume). PAN, Instytut Botaniki. Seria Flora Słodkowodna Polski, 
t. 10. Warszawa-Kraków: Państwowe Wydawnictwo Naukowe, 1972, ss. 750, [1] [zawiera Skorowidz nazw łacińskich; Klucz do oznaczania zielenic nitkowatych w języku angielskim].

\section{3}

Atlas roślin uprawnych. Teksty pol. oprac. Barbara Dąbrowska et al. Tabl. barwne wykonały Csapody Vera, Maria Antuszewicz. Budapest: Akadémiai Kiadó - Warszawa: Państwowe Wydawnictwo Rolnicze i Leśne, 1973, ss. 58, k. tabl. kolor luź. 130.

Laskowska Wanda. Rośliny borów. Tabl. wykonała z natury Hanna Rembertowicz-Szymborska. Wyd. 3. Warszawa: Państwowe Zakłady Wydawnictw Szkolnych, 1973, ss. 145, [2].

Rostafiński Józef, Seidl Olga. Przewodnik do oznaczenia roślin. Wyd. 20. Warszawa: Państwowe Wydawnictwo Rolnicze i Leśne, 1973, ss. 441, [3] [indeksy].

Słownik nazw roślin pochodzenia obcego łacińsko-polski i polsko-łaciński. Red. Ludmiła Karpowiczowa. Uniwersytet Warszawski, Ogród Botaniczny. Warszawa: Wydawnictwa Uniwersytetu Warszawskiego, 1973, ss. 313, [1].

Słownik nazw roślin pochodzenia obcego łacińsko-polski i polsko-łaciński. Suplement 1. Red. Ludmiła Karpowiczowa. Uniwersytet Warszawski, Ogród Botaniczny. Warszawa: Wydawnictwa Uniwersytetu Warszawskiego, 1973, ss. 40.

Walas Jan. Atlas roślin chronionych. Rys. roślin wykonała J. Malczyńska et al. Warszawa: Liga Ochrony Przyrody, 1973, ss. 196, [1].

Wrońska Irena. Zielnik mchów tatrzańskich dr Tytusa Chałubińskiego w Muzeum jego im. w Zakopanem. Zakopane: Muzeum Tatrzańskie, 1973, k. [1], 29.

\section{4}

Kwiaty ogrodów skalnych. Tekst Čestmír Böhm. Tablice barwne Jaromír Windsor, Karel Švarc. Przeł. Aleksander Ostrowski. Warszawa: Państwowe Wydawnictwa Rolnicze i Leśne, 1974, ss. 235, [1] [zawiera Skorowidz].

Mały atlas róż. Tekst Ludvík Večeřa. Tabl. barwne Jiřina Kaplická. Przeł. Aleksander Ostrowski. Warszawa: Państwowe Wydawnictwo Rolnicze i Leśne, 1974, ss. 238, [1] [zawiera Skorowidz].

Mądalski Józef. Atlas flory polskiej i ziem ościennych = Florae polonicae terrarumque adiacentium iconographia. T. 3, z. 4: Cyperaceae - Caricoideae (pars 3). Tablice oprac. Tadeusz Kowal i Jadwiga Mikulska. Tekst łaciński w tłum. J. Mądalskiego i E. Jacaka. Polska Akademia Nauk. Instytut Botaniki. Warszawa [etc.]: Państwowe Wydawnictwo Naukowe, 1974, teka (ss. 74, k. tabl. luź. 36).

Mowszowicz Jakub. Zarys systematyki roślin dla słuchaczy studiów uniwersyteckich. Warszawa: Państwowe Wydawnictwo Naukowe, 1974, ss. 317, [2] [zawiera indeksy].

Podbielkowski Zbigniew. Słownik roślin użytkowych: polski, łaciński, angielski, francuski, niemiecki, rosyjski. Wyd. 3. Warszawa Państwowe Wydawnictwa Rolnicze i Leśne, 1974, ss. 523, [1].

Porosty (Lichenes). Z. 2. Red. Jerzy Szweykowski i Teofil Wojterski. Oprac. Jerzy Szweykowski, Zygmunt Tobolewski i Bogdana Kupczyk. PAN Komitet Botaniczny i Instytut Botaniki. Seria Atlas rozmieszczenia roślin zarodnikowych w Polsce $=$ Atlas 
of Geographical Distribution of Spore-plants in Poland, Ser. 3. Poznań - Warszawa: Państwowe Wydawnictwo Naukowe. Oddział, 1974, teka (ss. 23, k. [10]) [tekst równoległy polski i przekład angielski].

Starmach Karol. Cryptophyceae - Kryptofity, Dinophyceae - Dinofity, Raphidophyceae - Rafidofity. Polska Akademia Nauk. Instytut Botaniki Seria Flora Słodkowodna Polski. Red. Karol Starmach, Jadwiga Siemińska, t. 4. Warszawa-Kraków: Państwowe Wydawnictwo Naukowe, 1974, ss. 519, [2] [zawiera Skorowidz nazw łacińskich; indeks].

Wątrobowce (Hepaticae). Liverworts (Hepaticae). Z. 8. Red. Jerzy Szweykowski i Teofil Wojterski. Oprac. Jerzy Szweykowski i Maria Koźlicka. Komitet Botaniczny PAN i Poznańskie Towarzystwo Przyjaciół Nauk, Wydział Matematyczno-Przyrodniczy, Komisja Biologiczna. Seria Atlas rozmieszczenia roślin zarodnikowych w Polsce = Atlas of Geographical Distribution of Spore-plants in Poland, Ser. 4. Poznań: Państwowe Wydawnictwo Naukowe. Oddział, 1974, teka (ss. 20, [5], k. [10]) [tekst równoległy polski, angielski].

\section{5}

Novák František A. Wielki atlas roślin. Przeł. Aleksander Ostrowski. Wyd. 2. Warszawa: Państwowe Wydawnictwo Rolnicze i Leśne, 1975, ss. 588, [3], s. fot.[32].

Roppel Leon. Poradnik kwiatowy. „Pomerania” 1975 nr 4, s. 9-11.

Traczyk Tadeusz. Rośliny lasu liściastego: [atlas]. Wyd. 4. Warszawa: Wydawnictwa Szkolne i Pedagogiczne, 1975, ss. 157, [2].

\section{6}

Atlas organizmów wskaźnikowych do oceny wód powierzchniowych. Red. Lesław Turoboyski. Aut. Danuta Chudyba et al. Seria Skrypty Akademii Rolniczo-Technicznej w Olsztynie. Olsztyn: Dział Wydawnictw, 1976, ss. 218.

Bednarz Zdzisław, Koczwańska Janina. Atlas roślin runa leśnego. Warszawa: Państwowe Wydawnictwo Rolnicze i Leśne, 1976, ss. 530, [1].

Mądalski Józef. Atlas flory polskiej i ziem ościennych = Florae polonicae terrarumque adiacentium iconographia. T. 2, z. 4: Liliaceae (pars 2). Tablice oprac. Elżbieta Skwirzyńska. Tekst łaciński w tłum. J. Mądalskiego i E. Jacaka. Polska Akademia Nauk. Instytut Botaniki. Warszawa [etc.]: Państwowe Wydawnictwo Naukowe, 1975, teka (ss. 63, k. tabl. luź. 39).

Mowszowicz Jakub. Dziko rosnące rośliny użytkowe. Tabl. wyk. z natury Hanna Rembertowicz-Szymborska. Seria Atlas, Warszawa: Wydawnictwa Szkolne i Pedagogiczne, 1975, ss. 172, [3].

Porosty (Lichenes). Z. 3. Red. Jerzy Szweykowski i Teofil Wojterski. Oprac. Jerzy Szweykowski, Zygmunt Tobolewski i Bogdana Kupczyk. PAN Komitet Botaniczny i Instytut Botaniki. Seria Atlas rozmieszczenia roślin zarodnikowych w Polsce = Atlas of Geographical Distribution of Spore-plants in Poland, Ser. 3.Poznań - Warszawa: Państwowe Wydawnictwo Naukowe.Oddział, 1976, teka (ss. 25, k. [10]) [tekst równoległy polski i przekład angielski].

Szafer Władysław, Kulczyński Stanisław, Pawłowski Bogumił. Rośliny polskie. Opisy i klucze do oznaczania wszystkich gatunków roślin naczyniowych rosnacych $w$ Polsce 
bądź dziko, bądź też zdziczałych lub częściej hodowanych. Wyd. 4. Warszawa: Państwowe Wydawnictwo Naukowe, 1976, ss. XXVIII, 1020 [indeksy].

Turowska Irena, Cyunel Elżbieta. Rośliny nasienne: przegląd systematyczny ze szczególnym uwzględnieniem gatunków leczniczych i użytkowych $z$ dodatkiem materiałów ćwiczeniowych i atlasu roślin. Atlas il. Zofia Brunarska. Wyd. 3 zm. Kraków: Akademia Medyczna im. M. Kopernika, 1976, ss. 273 + Atlas, ss. 24.

Turowska Irena, Podbielkowski Zbigniew, Wojewoda Władysław. Rośliny zarodnikowe. Atlas il. Zofia Brunarska. Wyd. 2 zm. Kraków: Akademia Medyczna im. M. Kopernika, 1976, ss. $210+$ Atlas, ss. 49.

\section{7}

Czarnota Krzysztof, Wysocki Czesław. Przegląd wyższych jednostek fitosocjologicznych Polski, wykaz gatunków charakterystycznych. Seria Skrypty Szkoły Głównej Gospodarstwa Wiejskiego Akademii Rolniczej w Warszawie. Warszawa: Wydawnictwo SGGW-AR, 1977, ss. 51 [Dla studentów i magistrantów Sekcji Ksztaltowania Terenów Zieleni Wydz. Ogrodniczego SGGW-AR].

Mądalski Józef. Atlas flory polskiej i ziem ościennych = Florae polonicae terrarumque adiacentium iconographia. T. 2, z. 1: Alismataceae, Butomaceae, Hydrocharitaceae, Juncaginaceae, Zannichelliaceae, Potamogetonaceae, Najadaceae. Tablice oprac. Anna Sadowska. Tekst łaciński w tłum. J. Mądalskiego i E. Jacaka. Polska Akademia Nauk. Instytut Botaniki. Warszawa [etc.]: Państwowe Wydawnictwo Naukowe, 1977, teka (ss. 94, k. tabl. luź. 45).

Mądalski Józef. Atlas flory polskiej i ziem ościennych = Florae polonicae terrarumque adiacentium iconographia. T. 5, z. 2: Orchidaceae (pars 2), Sparganiaceae, Typhaceae, Araceae, Lemnaceae (34 tablice). Tablice oprac. Jadwiga Mikulska. Tekst łacińcki w tłum. J. Mądalskiego i E. Jacaka. Polska Akademia Nauk. Instytut Botaniki. Warszawa [etc.]: Państwowe Wydawnictwo Naukowe, 1977, ss. 57, s. tabl. 71-604.

Porosty (Lichenes). Z. 4. Red. Jerzy Szweykowski i Teofil Wojterski. Oprac. Jerzy Szweykowski, Zygmunt Tobolewski i Bogdana Kupczyk. PAN Komitet Botaniczny i Instytut Botaniki. Seria Atlas rozmieszczenia roślin zarodnikowych w Polsce = Atlas of Geographical Distribution of Spore-plants in Poland, Ser. 3. Poznań - Warszawa: Państwowe Wydawnictwo Naukowe. Oddział, 1977, teka (ss. 42, k. [10]) [tekst równoległy polski i przekład angielski].

Wątrobowce (Hepaticae). Liverworts (Hepaticae) Z. 9. Red. Jerzy Szweykowski i Teofil Wojterski. Oprac. Jerzy Szweykowski, i Maria Koźlicka. PAN Komitet Botaniczny i Instytut Botaniki. Seria Atlas rozmieszczenia roślin zarodnikowych w Polsce = Atlas of Geographical Distribution of Spore-plants in Poland, Ser. 4. Poznań - Warszawa: Państwowe Wydawnictwo Naukowe. Oddział, 1977, teka (ss. 32, [3], k. [10]) [tekst równoległy polski i przekład angielski].

Wojewoda Władysław. Podstawczaki (Basidiomycetes): trzęsakowe (Tremellales), uszakowe (Auriculariales), czerwcogrzybowe (Septobasidiales). Red. J. Kochman i A. Skiergiełło. Instytut Botaniki PAN. Seria Flora Polska. Rośliny Zarodnikowe Polski i Ziem Ościennych. Grzyby (Mycota), t. 8. Warszawa-Kraków Państwowe Wydawnictwo Naukowe. Oddział, 1977, ss. 334, [4] [zawiera Indeks nazw polskich i łacińskich.] 


\section{8}

Burdajewicz Stanisław, Glaser Tadeusz. Atlas chorób i szkodników roślin ozdobnych,. Warszawa: Państwowe Wydawnictwo Rolnicze i Leśne, 1978, ss. 208.

Krause Joanna, Lisiecka Anna. Rośliny ozdobne. Cz. 1: Rośliny ozdobne uprawiane w gruncie. Seria Skrypty Akademii Rolniczej w Poznaniu. Wyd. 2 uzup. Poznań: Wydawnictwo Akademii Rolniczej, 1978, ss. 158 [Skorowidz nazw łacińskich; Słowniczek częściej spotykanych nazw łacińskich].

Mądalski Józef. Atlas flory polskiej i ziem ościennych = Florae polonicae terrarumque adiacentium iconographia. T. 2, z. 3: Liliaceae (pars 1). Tablice oprac. Elżbieta Skwirzyńska. Tekst łaciński w tłum. J. Mądalskiego i E. Jacaka. Polska Akademia Nauk. Instytut Botaniki. Warszawa [etc.]: Państwowe Wydawnictwo Naukowe, 1978, teka (ss. 68, k. tabl. luź. 38).

Rusin Maria. Słownik roślin ozdobnych i innych rosyjsko-łacińsko-polski. Skrypty dla Szkół Wyższych. Kraków: Akademia Rolnicza, 1978, ss. 72 [Słownik jest przeznaczony przede wszystkim dla studentów Wydziału Ogrodniczego (stacjonarnych i zaocznych) do samodzielnej pracy z literatura specjalistyczna tak na lektoratach, jak i $w$ domu].

\section{9}

Atlas skamieniałości przewodnich i charakterystycznych. Cz. 2a: Mezozoik: trias. Red. nauk. Lidia Malinowska. Aut. Leon Karczewski et al. Instytut Geologiczny Seria Budowa geologiczna Polski, t. 3. Warszawa: Wydawnictwa Geologiczne, druk 1979, ss. 286, s. tabl. LXXVIII, k. tabl. złoż. [7] [spisy].

Gayówna Delfina. Rośliny łąk: [atlas]. Tablice wykonała Ewa Śliwińska. Rys. kreskowe wykonała Hanna Rembertowicz-Szymborska. Wyd. 4. Warszawa: Wydawnictwa Szkolne i Pedagogiczne, 1979, ss. 158, [2].

Glaser Tadeusz, Suski Zbigniew. Ochrona roślin ogrodniczych. Wyd. 3. Warszawa: Państwowe Wydawnictwo Rolnicze i Leśne, 1979, ss. 403, [1] [zawiera Skorowidz nazw polskich i łacińskich].

Krejča Jindřich, Klimo Julius. Kwiaty letnie: barwny atlas najpiękniejszych kwiatów jednorocznych i dwuletnich. Z jęz. słowac. przeł. Herman Grzeszczyk. Wyd. 2. Warszawa: Państwowe Wydawnictwo Rolnicze i Leśne, 1979, ss. 125, [2].

Mądalski Józef, Atlas flory polskiej i ziem ościennych = Florae polonicae terrarumque adiacentium iconographia. T. 3, z. 1: Cyperaceae - Scirpoideae, Rhynchosporoideae, (43 Tablice). Tablice oprac. Jadwiga Mikulska. Tekst łaciński w tłum. J. Mądalskiego i E. Jacaka. Polska Akademia Nauk. Instytut Botaniki. Warszawa [etc.]: Państwowe Wydawnictwo Naukowe, 1979, ss. 67, III, tabl. s. 239-274.

Mowszowicz Jakub. Zarys systematyki roślin dla słuchaczy studiów uniwersyteckich. Wyd. 2. Warszawa: Państwowe Wydawnictwo Naukowe, 1979, ss. 317, [2] [zawiera indeksy].

Novák František A. Wielki atlas roślin Przeł. Aleksander Ostrowski. Wyd. 3. Warszawa: Państwowe Wydawnictwo Rolnicze i Leśne, 1979, ss. 588, [3], s. fot. kolor. [32].

Porosty (Lichenes). Z. 5. Red. Jerzy Szweykowski i Teofil Wojterski. Oprac. Jerzy Szweykowski, Zygmunt Tobolewski i Bogdana Kupczyk. PAN Komitet Botaniczny i Instytut Botaniki. Seria Atlas rozmieszczenia roślin zarodnikowych w Polsce $=$ Atlas 
of Geographical Distribution of Spore-plants in Poland, Ser. 3. Poznań - Warszawa: Państwowe Wydawnictwo Naukowe. Oddział, 1979, teka (ss. 29, k. [10]) [tekst równoległy polski i przekład angielski].

Rostafiński Józef, Seidl Olga. Przewodnik do oznaczenia roślin. Wyd. 21. Warszawa: Państwowe Wydawnictwo Rolnicze i Leśne, 1979, ss. 441, [3] [indeksy].

\section{0}

Drzewa Europy Środkowej. Tekst Jaromír Pokorný. Tablice barwne Jiřina Kaplická. Tłum. Aleksander Ostrowski. Warszawa: Państwowe Wydawnictwo Rolnicze i Leśne, 1980, ss. 184 [Zawiera Indeks nazw polskich i łacińskich].

Jasiewicz Adam, Tacik Tadeusz. Dwuliścienne. Cz. 9: Zrosłopłatkowe. Cz. 5. Polska Akademia Nauk, Instytut Botaniki. Seria Flora Polska. Rośliny Naczyniowe Polski i Ziem Ościennych, t. 14. Warszawa-Kraków: Państwowe Wydawnictwo Naukowe, 1980, ss. 351 [zawiera Skorowidz nazw systematycznych w języku łacińskim; indeks]. Mowszowicz Jakub. Zarys systematyki roślin dla słuchaczy studiów uniwersyteckich.

Wyd. 2. Warszawa: Państwowe Wydawnictwo Naukowe, 1980, ss. 317, [2] [zawiera indeksy].

Piątkowska Krystyna, Zaleska Józefa. Drzewa, krzewy i pnącza w osiedlach mieszkaniowych. Warszawa: Zakład Wydawnictw CZSR, 1980, ss. 206, [2] [zawiera Indeks nazw łacińskich i polskich].

Podbielkowski Zbigniew. Słownik roślin użytkowych: polski, łaciński, angielski, francuski, niemiecki, rosyjski. Wyd. 4. Warszawa: Państwowe Wydawnictwo Rolnicze i Leśne, 1980, ss. 528, [4].

Porosty (Lichenes). Z. 6. Red. Jerzy Szweykowski i Teofil Wojterski. Oprac. Jerzy Szweykowski, Zygmunt Tobolewski i Bogdana Kupczyk. PAN Komitet Botaniczny i Instytut Botaniki. Seria Atlas rozmieszczenia roślin zarodnikowych w Polsce = Atlas of Geographical Distribution of Spore-plants in Poland, Ser. 3. Poznań-Warszawa: Państwowe Wydawnictwo Naukowe. Oddział, 1980, teka (ss. 29, k. [10]) [tekst równoległy polski i przekład angielski].

Seneta Włodzimierz. Drzewa i krzewy iglaste. Warszawa: Państwowe Wydawnictwo Naukowe, 1981, ss. 560, s. tabl. [46] [indeks].

Watrobowce (Hepaticae). Liverworts (Hepaticae). Z. 10. Red. Jerzy Szweykowski i Teofil Wojterski. Oprac. Jerzy Szweykowski, Jerzy Szweykowski i Maria Koźlicka. PAN Komitet Botaniczny i Inst. Botaniki. Seria Atlas rozmieszczenia roślin zarodnikowych w Polsce $=$ Atlas of Geographical Distribution of Spore-plants in Poland, Ser. 4. Poznań - Warszawa: Państwowe Wydawnictwo Naukowe. Oddział, 1980, teka (ss. 30, [3], k. [1]) [tekst równoległy polski i przekład angielski].

Włodarczyk Stanisław. Botanika łąkarska, [Podręcznik dla techników rolniczych o specjalności łąkarskiej]. Wyd. 4, popr. i uzup. Warszawa: Państwowe Wydawnictwo Rolnicze i Leśne, 1980, ss. 277, [1] [zawiera Skorowidz polsko-łaciński i łacińsko-polski nazw roślin].

\section{1}

Atlas skamieniałości przewodnich i charakterystycznych. Cz. 2b: Mezozoik: jura. Red. nauk. Lidia Malinowska. Aut. Wiesław Barczyk et al. Instytut Geologiczny. Seria 
Budowa geologiczna Polski, t. 3. Warszawa: Wydawnictwa Geologiczne, dr. 1981, ss. 641, s. tabl. CLXXX, k. tabl. złoż. [4] [spisy].

Berbeć Stanisław et al. Morfologia i biologia roślin uprawnych + Atlas. Red. Stanisław Tabin. Wyd. 2. Lublin: Wydawnictwo Akademii Rolniczej, 1981, ss. 195 + Atlas.

Nespiak Andrzej. Podstawczaki (Basidiomycetes): bedłkowe (Agaricales), zasłonakowate (Cortinariaceae), zasłonak II (Cortinarius II). Red. J. Kochman i A. Skirgiełł. Instytut Botaniki PAN. Seria Flora Polska. Rośliny Zarodnikowe Polski i Ziem Ościennych. Grzyby (Mycota), t. 14. Warszawa-Kraków: Państwowe Wydawnictwo Naukowe. Oddział, 1981, ss. 218, [2] [zawiera Indeks nazw polskich i łacińskich].

Porosty (Lichenes). Z. 7. Red. Jerzy Szweykowski i Teofil Wojterski. Oprac. Jerzy Szweykowski, Zygmunt Tobolewski. PAN Komitet Botaniczny i Instytut Botaniki. Seria Atlas rozmieszczenia roślin zarodnikowych w Polsce $=$ Atlas of Geographical Distribution of Spore-plants in Poland, Ser. 3. Poznań - Warszawa: Państwowe Wydawnictwo Naukowe, Oddział, 1981, teka (ss. 37, k. [10]) [tekst równoległy polski i przekład angielski].

Seneta Włodzimierz. Drzewa i krzewy iglaste. Warszawa: Państwowe Wydawnictwo Naukowe, 1981, ss. 560, 92 k. tabl. [zawiera Skorowidz nazw łacińskich i polskich].

Zarzycki Kazimierz. Rośliny naczyniowe Pienin: rozmieszczenie i warunki wystepowania $=$ The Vascular plants of the Pieniny Mts. (West Carpathians): distribution and habitats. Polska Akademia Nauk. Instytut Botaniki, Warszawa-Kraków: Państwowe Wydawnictwo Naukowe, 1981, ss. 257 [spisy].

\section{2}

Chlebowski Bolesław, Mynett Kazimierz. Kwiaciarstwo. Podręcznik dla techników ogrodniczych i policealnych studiów zawodowych. Wyd. 2. Warszawa: Państwowe Wydawnictwo Rolnicze i Leśne, 1982, ss. 283, [1] [zawiera Wykaz łacińskich i polskich nazw rodzajów gatunków roślin].

Mowszowicz Jakub. Zarys systematyki roślin dla słuchaczy studiów uniwersyteckich. Wyd. 3. Warszawa: Państwowe Wydawnictwo Naukowe, 1982, ss. 317, [2] [zawiera indeksy].

Słownik nazwisk zoologicznych i botanicznych polskich, zawierajacy ludowe oraz naukowe nazwy i synonimy polskie, używane dla zwierząt i roślin od XV-go wieku do chwili obecnej. Źródłowo zebrane i zestawione z synonimami naukowemi łacińskiemi w podwójnym porządku alfabetycznym i pomnożone porównawczym materyałem, zaczerpniętym z innych języków słowiańskich. T. 1: Słownik polsko-łaciński. Ułożył Erazm Majewski. Warszawa: Wydawnictwa Artystyczne i Filmowe na zam. Zjednoczenia Księgarstwa, 1982, ss. LXIV, 546.

Słownik nazwisk zoologicznych i botanicznych polskich, zawierajacy ludowe oraz naukowe nazwy i synonimy polskie, używane dla zwierząt i roślin od XV-go wieku do chwili obecnej. Źródłowo zebrane i zestawione z synonimami naukowemi łacińskiemi w podwójnym porządku alfabetycznym i pomnożone porównawczym materyałem, zaczerpniętym z innych języków słowiańskich. T. 2: Słownik łacińsko-polski pomnożony prównawczym materyałem, zaczerpniętym $z$ innych języków słowiańskich. 
Ułożył Erazm Majewski. Warszawa: Wydawnictwa Artystyczne i Filmowe na zam. Zjednoczenia Księgarstwa, 1982, ss. [4], XLVII, XI, 888, [2].

\section{3}

Krause Joanna, Lisiecka Anna. Rośliny ozdobne. Cz. 1: Rośliny ozdobne uprawiane w gruncie. Seria Skrypty Akademii Rolniczej w Poznaniu. Wyd. 3 uzup. Poznań: Wydawnictwo Akademii Rolniczej, 1983 ss. 155 [zawiera Skorowidz nazw łacińskich; Słowniczek częściej spotykanych nazw łacińskich].

Laskowska Wanda. Rośliny borów, tabl. wykonała z natury Hanna Rembertowicz-Szymborska. Wwyd. 4. Warszawa: Wydawnictwa Szkolne i Pedagogiczne, 1983, ss. 146.

Mądalski Józef. Atlas flory polskiej i ziem ościennych = Florae polonicae terrarumque adiacentium iconographia. T. 6, z. 2: Salicaceae. Tablice oprac. Elżbieta Skwirzyńska. Tekst łaciński w tłum. J. Mądalskiego i E. Jacaka. Polska Akademia Nauk. Instytut Botaniki. Warszawa [etc.]: Państwowe Wydawnictwo Naukowe, 1983, teka (ss. 75, k. tabl. luź. 32).

Mowszowicz Jakub. Zarys systematyki roślin dla słuchaczy studiów uniwersyteckich. Wyd. 3, dodruk. Warszawa: Państwowe Wydawnictwo Naukowe, 1983, ss. 317, [2] [zawiera indeksy].

Porosty (Lichenes). T. 1, cz. 1. Oprac. Janusz Nowak. Rys. Barbara Tarnowska-Kownacka. Polska Akademia Nauk. Instytut Botaniki. Seria Flora Polska. Rośliny Zarodnikowe Polski i Ziem Ościennych. Porosty (Lichenes), t. 1, cz. 1. Warszawa-Kraków: Państwowe Wydawnictwo Naukowe, 1983, ss. 241, [4], s. tabl. XXXI [zawiera Skorowidz systematycznych nazw łacińskich; indeks].

Porosty (Lichenes). Z. 8. Red. Jerzy Szweykowski i Teofil Wojterski. Oprac. Jerzy Szweykowski, Zygmunt Tobolewski. PAN Komitet Botaniczny i Inst. Botaniki. Seria Atlas rozmieszczenia roślin zarodnikowych w Polsce = Atlas of Geographical Distribution of Spore-plants in Poland, Ser. 3. Poznań-Warszawa: Państwowe Wydawnictwo Naukowe, Oddział, 1983, teka (ss. 30, k. [10]) [tekst równoległy polski i przekład angielski].

Słownik nazwisk zoologicznych i botanicznych polskich, zawierajaccy ludowe oraz naukowe nazwy i synonimy polskie, używane dla zwierząt i roślin od XV-go wieku do chwili obecnej. Źródłowo zebrane i zestawione z synonimami naukowemi łacińskiemi w podwójnym porządku alfabetycznym i pomnożone porównawczym materyałem, zaczerpniętym z innych języków słowiańskich. T. 1: Słownik polsko-łaciński. Cz. 2: $M-Z$, [= Dictionnaire des noms Polonais zoologiques et botaniques contenant les noms vulgaires et littéraires Polonais, donnés aux animaux et aux végétaux depuis le $X V$-me siècle jusqu'a nos jours. Vol. 2: Dictionaire latin-polonais. Pt. 2: M-Z]. Ułożył Erazm Majewski. Warszawa: Wydawnictwa Artystyczne i Filmowe na zam. Zjednoczenia Księgarstwa, 1983, ss. [4], 457-888, [2].

Słownik nazwisk zoologicznych i botanicznych polskich, zawierajacy ludowe oraz naukowe nazwy i synonimy polskie, używane dla zwierząt i roślin od XV-go wieku do chwili obecnej. Źródłowo zebrane i zestawione z synonimami naukowemi łacińskiemi w podwójnym porządku alfabetycznym i pomnożone porównawczym materyałem, zaczerpniętym z innych języków słowiańskich. T. 2: Słownik łacińsko-polski pomno- 
żony prównawczym materyałem, zaczerpniętym $z$ innych języków słowiańskich. Cz. 1: A-M, [= Dictionnaire des noms Polonais zoologiques et botaniques contenant les noms vulgaires et littéraires Polonais, donnés aux animaux et aux végétaux depuis le XV-me siècle jusqu'a nos jours. Vol. 2: Dictionaire latin-polonais. Pt. 1: A-M]. Ułożył Erazm Majewski. Warszawa: Wydawnictwa Artystyczne i Filmowe na zam. Zjednoczenia Księgarstwa, 1983, ss. [4], XLVII, XI, 466 [przedr., oryg.: Warszawa: nakł. autora: skł. gł. w księgarni Teodora Paprockiego i S-ki, 1894].

Włodarczyk Stanisław. Botanika łąkarska, [Podręcznik dla techników rolniczych o specjalności łąkarskiej]. Wyd. 5. Warszawa: Państwowe Wydawnictwo Rolnicze i Leśne, 1983, ss. 277, [3] [zawiera Skorowidz polsko-łaciński i łacińsko-polski nazw roślin].

\section{4}

Atlas skamieniałości przewodnich i charakterystycznych. Cz. 2c: Mezozoik: kreda. Red. nauk. Lidia Malinowska. Aut. Andrzej Błaszkiewicz et al. Instytut Geologiczny. Seria Budowa geologiczna Polski, t. 3. Warszawa: Wydawnictwa Geologiczne, 1984, ss. 579, s. tabl. CCXIV, k. tabl. złoż. [2] [spisy].

Krejča Jindřich, Klimo Julius. Kwiaty letnie: barwny atlas najpiękniejszych kwiatów jednorocznych i dwuletnich Z jęz. słowac. przeł. Herman Grzeszczyk. Wyd. 3. Warszawa: Państwowe Wydawnictwo Rolnicze i Leśne, 1984, ss. 125, [2].

Rutkowska Barbara. Atlas roślin łąkowych i pastwiskowych: 160 gatunków. Tabl. barwne wykonała $z$ natury Hanna Rembertowicz-Szymborska. Wyd. 2 uzup. i rozsz. Warszawa: Państwowe Wydawnictwo Rolnicze i Leśne, 1984, ss. 367, [1].

Schubert Margot, Herwig Rob. Mieszkamy wśród kwiatów. Tł. Anna Rudowska, Inga Szwedler. Warszawa: Państwowe Wydawnictwo Rolnicze i Leśne, 1984, ss. 374, [2] [zawiera Wykaz łacińskich nazw roślin i ich odmian, s. 366-[375]; Wykaz polskich nazw roślin, s. 361-365; Dodatek dla szukających szybkiej informacji, s. 357-360].

Sendek Andrzej. Rośliny naczyniowe Górnośląskiego Okręgu Przemysłowego. Opolskie Towarzystwo Przyjaciół Nauk. Wydział III Nauk Przyrodniczych. Warszawa-Wrocław: Państwowe Wydawnictwo Naukowe, 1984, ss. 137 [spisy].

Włodarczyk Stanisław. Botanika łąkarska, [Podręcznik dla techników rolniczych o specjalności łąkarskiej]. Wyd. 6. Warszawa: Państwowe Wydawnictwo Rolnicze i Leśne, 1984, ss. 277, [3] [zawiera Skorowidz polsko-łaciński i łacińsko-polski nazw roślin].

\section{5}

Dykcyonarz roslinny, w którym podług układu Linneusza sq opisane rosliny nietylko kraiowe dzikie, pożyteczne, albo szkodliwe: na roli, w ogrodach, oranżeryach, utrzymywane: ale oraz i cudzoziemskie, ktoreby w kraiu pożyteczne być mogly: albo z ktorych mamy lekarstwa, korzenie, farby, $i$ t.d. albo ktore jakowa nadzwyczaynosc $w$ sobie maia: ich zdatnosci lekarskie, ekonomiczne, dla ludzi, koni, bydła, owiec, pszczoł, $i$ t.d. utrzymywanie, i t.d. z poprzedzaiącym wykładem słów botanicznych, i kilkokrotnym na końcu reiestrem. T. 1: A-E. Ułożony przez X. Krzysztofa Kluka. Warszawa: Wydawnictwa Artystyczne i Filmowe na zam. Zjednoczenia Księgarstwa, 1985, ss. [4], XLII, 214, [2] [przedr. fotooffsetowy, oryg.: Warszawa: w Drukarni Xięży Piarów, 1805]. 
Dykcyonarz roslinny, w którym podtug układu Linneusza sa opisane rosliny nietylko kraiowe dzikie, pożyteczne, albo szkodliwe: na roli, w ogrodach, oranżeryach, utrzymywane: ale oraz i cudzoziemskie, ktoreby w kraiu pożyteczne być mogly: albo z ktorych mamy lekarstwa, korzenie, farby, i t.d. albo ktore jakowa nadzwyczaynosc w sobie maia: ich zdatnosci lekarskie, ekonomiczne, dla ludzi, koni, bydła, owiec, pszczoł, $i$ t.d. utrzymywanie, i t.d. z poprzedzaiącym wykładem słów botanicznych, i kilkokrotnym na końcu reiestrem. T. 2: F-Q. Ułożony przez X. Krzysztofa Kluka. Warszawa: Wydawnictwa Artystyczne i Filmowe na zam. Zjednoczenia Księgarstwa, 1985, ss. [4], 256, [2] [przedr. fotooffsetowy, oryg.: Warszawa: w Drukarni Xięży Piarów, 1808].

Dykcyonarz roslinny, w którym podług układu Linneusza sa opisane rosliny nietylko kraiowe dzikie, pożyteczne, albo szkodliwe: na roli, w ogrodach, oranżeryach, utrzymywane: ale oraz i cudzoziemskie, ktoreby w kraiu pożyteczne być mogly: albo z ktorych mamy lekarstwa, korzenie, farby, i t.d. albo ktore jakowa nadzwyczaynosc $w$ sobie maia: ich zdatnosci lekarskie, ekonomiczne, dla ludzi, koni, bydła, owiec, pszczoł, $i$ t.d. utrzymywanie, i t.d. z poprzedzaiącym wykładem słów botanicznych, i kilkokrotnym na końcu reiestrem. T. 3: R-Z. Ułożony przez X. Krzysztofa Kluka. Warszawa: Wydawnictwa Artystyczne i Filmowe na zam. Zjednoczenia Księgarstwa, 1985, ss. 196, [4] [przedr. fotooffsetowy, oryg.: Warszawa: w Drukarni Xięży Piarów, 1811].

Dwuliścienne wolnopłatkowe - dwuokwiatowe. Cz. 1. Oprac. Maria Gostyńska-Jakuszewska et al. Polska Akademia Nauk. Instytut Botaniki. Seria Flora Polski: rośliny naczyniowe, t. 4, wyd. 2. Warszawa-Kraków: Państwowe Wydawnictwo Naukowe, 1985, ss. 306, [1] [zawiera Skorowidz nazw systematycznych w języku łacińskim; indeks].

Mchy (Musci). Z. 2. Red. Zygmunt Tobolewski i Teofil Wojterski. Oprac. Ryszard Ochyra, Anna Rusińska i Piotr Szmajda. PAN Komitet Botaniki i Instytut Botaniki. Atlas rozmieszczenia roślin zarodnikowych $\mathrm{w}$ Polsce $=$ Atlas of the Geographical Distribution of Spore Plants in Poland, Ser. 5. Warszawa-Poznań: Państwowe Wydawnictwo Naukowe, 1985, teka (s. 32, k. [10]) [tekst równoległy polski i przekład angielski].

Podbielkowski Zbigniew. Słownik roślin użytkowych: polski, łaciński, angielski, francuski, niemiecki, rosyjski. Wyd. 5. Warszawa: Państwowe Wydawnictwo Rolnicze i Leśne, 1985, ss. 529, [3]

Porosty (Lichenes). Z. 9. Red. Jerzy Szweykowski i Teofil Wojterski. Oprac. Jerzy Szweykowski, Zygmunt Tobolewski. PAN Komitet Botaniczny i Instytut Botaniki. Seria Atlas rozmieszczenia roślin zarodnikowych $\mathrm{w}$ Polsce $=$ Atlas of Geographical Distribution of Spore-plants in Poland, Ser. 3. Poznań-Warszawa: Państwowe Wydawnictwo Naukowe, 1988, teka (ss. 46, k. [10]) [tekst równoległy polski i przekład angielski].

Rodkiewicz Bohdan. Embriologia roślin nagozalażkowych. Warszawa: Państwowe Wydawnictwo Naukowe, 1984, ss. 419, [1], s. tabl. [16] [zawiera Skorowidz nazw łacińskich; indeks].

Rośliny polskie. Opisy i klucze do oznaczania wszystkich gatunków roślin naczyniowych rosnacych w Polsce bądź dziko, bądź też zdziczalych lub częściej hodowanych. 
Cz. 1-2. Oprac. Władysław Szafer, Stanisław Kulczyński, Bogumił Pawłowski. Wyd. 5. Warszawa: Państwowe Wydawnictwo Naukowe, 1986, ss. 1019 [Spis łacińskich nazw rodzin, rodzajów i gatunków; Spis polskich nazw rodzin i rodzajów].

Rusin Maria. Słownik roślin ozdobnych i innych rosyjsko-łacińsko-polski. Skrypty dla Szkół Wyższych. Wyd. 2. Kraków: Akademia Rolnicza, 1985, ss. 72 [Słownik jest przeznaczony przede wszystkim dla studentów Wydziału Ogrodniczego (stacjonarnych $i$ zaocznych) do samodzielnej pracy z literatura specjalistyczna tak na lektoratach jak iw domu].

Uniwersalna Klasyfikacja Dziesiętna. FID 607: 58. Botanika. Oprac. red. całości: Bożenna Klaga. Adiustacja klasyfikacyjna: Bożenna Klaga, Henryka Golasowska. Oprac. indeksu Ryszard Dopierała - indeks terminologii polskiej, Bożenna Klaga - indeks terminologii łacińskiej. Instytut Informacji Naukowej,Technicznej i Ekonomicznej, Zakład Teorii Języków Informacyjnych, 2 wyd. pełne w jęz. pol., aktualne na dzień 1.VII.1985 r., (wł. Extensions and Corrections to the UDC, seria, 12, nr 2). Warszawa: Centrum Informacji Naukowej, Technicznej i Ekonomicznej, 1985, ss. 98, XII [wyd. oprac. na podst.: pierwszego pełnego wyd. polskiego UKD działu 58, 1965, publ. FID nr 327; pełnego wydania UKD działu 58 w jęz. włoskim (Classificazione Decimale Universale, Ed. compl. italiana, 1979, publ. FID nr 479, z uwzględnieniem oficjalnych zmian i uzupełnień zamieszczonych w „Extensions and corrections to the UDC” włącznie z nr 2 serii 12, publ. FID 248].

\section{6}

Fabiszewski Jerzy. Rośliny Sudetów. Atlas. Tablice wykonał Władysław Micek. Wyd. 2. Warszawa: Wydawnictwa Szkolne i Pedagogiczne, 1986, ss. 159, [1].

Lista roślin wymierających i zagrożonych $w$ Polsce $=$ List of threatened plants in Poland . Red. Kazimierz Zarzycki, Władysław Wojewoda przy współudziale Zofii Heinrich. PAN, Komitet Ochrony Przyrody i Instytut Botaniki. Warszawa: Państwowe Wydawnictwo Naukowe, 1986, ss. 134.

Mowszowicz Jakub. Zarys systematyki roślin dla słuchaczy studiów uniwersyteckich. Wyd. 4. Warszawa: Państwowe Wydawnictwo Naukowe, 1986, ss. 317, [2] [zawiera indeksy].

Novák František A. Wielki atlas roślin. Przeł. Aleksander Ostrowski. Wyd. 4. Warszawa: Państwowe Wydawnictwo Rolnicze i Leśne, 1986, ss. 588, [3], ss. fot. kolor. [32].

Szafer Władysław, Kulczyński Stanisław, Pawłowski Bogumił. Rośliny polskie: opisy i klucze do oznaczania wszystkich gatunków roślin naczyniowych rosnących $w$ Polsce bądź dziko, bądź też zdziczałych lub częściej hodowanych. Cz. 1-2. Wyd. 5. Warszawa: Państwowe Wydawnictwo Naukowe, 1986, 2 cz. (ss. XXXI, 464; 465-1019) [Spis łacińskich nazw rodzin, rodzajów i gatunków; Spis polskich nazw rodzin i rodzajów].

Wojewoda Władysław, Ławrynowicz Maria. Czerwona lista grzybów wielkoowocnikowych zagrożonych $w$ Polsce $=$ Red list of threatened macrofungi in Poland. Warszawa: Państwowe Wydawnictwo Naukowe, 1986, s. [47]-82 [nadb. z: Lista roślin wymierajacych i zagrożonych $w$ Polsce. Red. Kazimierz Zarzycki i Władysław Wojewoda. Warszawa, 1986] 


\section{7}

Seneta Włodzimierz. Drzewa i krzewy iglaste. Cz. 2. Wyd. 2. Warszawa: Państwowe Wydawnictwo Naukowe, 1987, ss. [2], 272-560, s. tabl. [26] [Skorowidz nazw łacińsko-polskich].

\section{8}

Charakterystyka odmian: rośliny warzywne. Red. nauk. Eugeniusz Bilski. Aut. G. Goździk et al. Słupia Wielka: Centralny Ośrodek Badań Odmian Roślin Uprawnych, 1988, ss. 300 [spisy].

Gayówna Delfina, Rośliny łąk: [atlas]. Tablice wykonała Ewa Śliwińska. Rys. kreskowe wykonała Hanna Rembertowicz-Szymborska. Wyd. 5. Warszawa: Wydawnictwa Szkolne i Pedagogiczne, 1988, ss. 158, [2].

Kiljańska Izabella, Mojkowska Hanna. Zielnik polski. Il. Bohdan Berg. Warszawa: Wydawnictwo Interpress, 1988, ss. 382.

Mastrenak Hanna, Wiech Kazimierz. Jaki to szkodnik, jaka choroba: atlas chorób i szkodników najczęściej wystepujących na działkach. Polski Związek Działkowców. Krajowa Rada w Warszawie. Seria Biblioteka Działkowca 52. Warszawa: Krajowa Rada Polskiego Związku Działkowców, 1988, ss. 136.

Mchy (Musci). Z. 3. Red. Zygmunt Tobolewski i Teofil Wojterski. Oprac. Ryszard Ochyra, Anna Rusińska i Piotr Szmajda. PAN, Komitet Botaniki i Instytut Botaniki, Atlas rozmieszczenia roślin zarodnikowych w Polsce $=$ Atlas of the Geographical Distribution of Spore Plants in Poland. Seria 5. Warszawa-Poznań: Państwowe Wydawnictwo Naukowe, 1988, teka (s. 60, k. [11]) [tekst równoległy polski i przekład angielski].

Mchy (Musci). Z. 4. Red. Zygmunt Tobolewski i Teofil Wojterski. Oprac. Ryszard Ochyra, Anna Rusińska i Piotr Szmajda. PAN, Komitet Botaniki i Instytut Botaniki, Atlas rozmieszczenia roślin zarodnikowych w Polsce $=$ Atlas of the Geographical Distribution of Spore Plants in Poland. Seria 5. Warszawa-Poznań: Państwowe Wydawnictwo Naukowe, 1988, teka (s. 48, k. [11]) [tekst równoległy polski i przekład angielski].

Szafer Władysław, Kulczyński Stanisław, Pawłowski Bogumił. Rośliny polskie: opisy $i$ klucze do oznaczania wszystkich gatunków roślin naczyniowych rosnacych $w$ Polsce bądź dziko, bądź też zdziczałych lub częściej hodowanych. Cz. 1-2. Wyd. 6. Warszawa: Państwowe Wydawnictwo Naukowe, 1988, 2 cz. (ss. XXXI, 464; 465-1019) [Spis łacińskich nazw rodzin, rodzajów i gatunków; Spis polskich nazw rodzin i rodzajów].

Sudnik-Wójcikowska Barbara, Koźniewska Beata. Słownik z zakresu synantropizacji szaty roślinnej. Warszawa: Wydawnictwa Uniwersytetu Warszawskiego, 1988, ss. 93, [1].

\section{9}

Macků Jan, Krejča Jindřich. Atlas roślin leczniczych. Tłum. ze słowac. Uaktualnił i uzup. Apoloniusz Rymkiewicz. Wrocław [etc.]: Zakład Narodowy im. Ossolińskich - Wydawnictwo, 1989, ss. 431. 
Podbielkowski Zbigniew. Słownik roślin użytkowych [polski, łaciński, angielski, francuski, niemiecki, rosyjski]. Wyd. 6. Warszawa: Państwowe Wydawnictwo Rolnicze i Leśne, 1989, ss. 529, [3] [Indeks nazw roślin w językach: angielskim, francuskim, łacińskim, niemieckim, rosyjskim].

Traczyk Tadeusz. Rośliny lasu liściastego: [atlas]. Wyd. 5. Warszawa: Wydawnictwa Szkolne i Pedagogiczne, 1989, ss. 158, [2].

\section{0}

Atlas skamieniałości przewodnich i charakterystycznych. Cz. 1a: Paleozoik starszy (z proterozoikiem górnym). Red. Mari Pajchlowa, Państwowy Instytut Geologiczny. Seria Budowa geologiczna Polski, t. 3. Warszawa: Wydawnictwa Geologiczne, 1990, ss. 558, 1. tabl. złoż. [8], s. tabl. 199.

Jakubiec Anna, Gąsowski Andrzej, Wojciechowska Dorota. Słownik specjalistyczny angielsko-polski, polsko-angielski z zakresu genetyki i hodowli roślin oraz nasiennictwa. Warszawa: Wydawnictwo SGGW-AR, 1990, ss. 183.

Leksykon roślin leczniczych. Red. Antonina Rumińska i Aleksander Ożarowski, zespół aut. Aleksander Ożarowski et al. Tablice barwne wykonali Bohdan Berg et al. Warszawa: Państwowe Wydawnictwo Rolnicze i Leśne, 1990, ss. 565, [1].

Mądalski Józef. Atlas flory polskiej i ziem ościennych = Florae polonicae terrarumque adiacentium iconographia, t. 2, z. 5: Liliaceae (pars 3), Amaryllidaceae, Iridaceae. Tablice oprac. Elżbieta Skwirzyńska. Polska Akademia Nauk. Instytut Botaniki. Kraków: Instytut Botaniki im. W. Szafera PAN, 1990, teka (ss. 53, k. tabl. luź. 36).

Mchy (Musci). Z. 5. Red. Ryszard Ochyra i Piotr Szmajda, Instytut Botaniki im. W. Szafera PAN - Uniwersytet im. A. Mickiewicza. Atlas rozmieszczenia roślin zarodnikowych $\mathrm{w}$ Polsce $=$ Atlas of the Geographical Distribution of Spore Plants in Poland. Seria 5. Kraków: Instytut Botaniki im. W. Szafera PAN -Poznań: UAM, 1990, ss. 52, k. [10] [tekst równoległy polski i przekład angielski].

Mchy (Musci). Z. 6. Red. Ryszard Ochyra i Piotr Szmajda. Instytut Botaniki im. W. Szafera PAN - Uniwersytet im. A. Mickiewicza. Atlas rozmieszczenia roślin zarodnikowych w Polsce $=$ Atlas of the Geographical Distribution of Spore Plants in Poland. Seria 5. Kraków: Instytut Botaniki im. W. Szafera PAN -Poznań: UAM, 1990, ss. 50, k. [11] [tekst równoległy polski i przekład angielski].

Mowszowicz Jakub. Dziko rosnące rośliny użytkowe, tabl. wyk. z natury Hanna Rembertowicz-Szymborska. Seria Atlas. Wyd. 2. Warszawa: Wydawnictwa Szkolne i Pedagogiczne, 1990, ss. 172, [3].

Słownik słów kluczowych z botaniki. Wybór i oprac. słów kluczowych z botaniki zespół w składzie Zbigniew Mirek et al. Ośrodek Informacji Naukowej w Warszawie, PAN. Kraków 1990, ss. 59.

Świejkowski Leonidas. Rośliny lecznicze i przemysłowe. Klucz do oznaczania. Tekst cz. I Józef Kiszka. Wyd. 2. Warszawa: Wydawnictwo Rynku Wewnętrznego Libra, 1990, ss. 649, [1] k. mapa, [48] s. tabl. [zawiera indeksy].

\section{1}

Bremness Lesley. Wielka księga ziół. Przekł. Joanna Cieśla et al. Seria Encyklopedia „Wiedzy i Życia”. Wyd. 6. Warszawa: Wiedza i Życie, cop. 1991, ss. 288. 
Krause Joanna, Lisiecka Anna. Rośliny ozdobne. Cz. 1: Rośliny ozdobne uprawiane w gruncie. Seria Skrypty Akademii Rolniczej w Poznaniu. Poznań: Wydawnictwo Akademii Rolniczej, 1991, ss. 147 [Skorowidz nazw łacińskich; Słowniczek częściej spotykanych nazw łacińskich].

Mchy (Musci). Z. 7. Red. Ryszard Ochyra i Piotr Szmajda, Instytut Botaniki im. W. Szafera PAN - Uniwersytet im. A. Mickiewicza. Atlas rozmieszczenia roślin zarodnikowych $\mathrm{w}$ Polsce $=$ Atlas of the Geographical Distribution of Spore Plants in Poland. Seria 5. Kraków: Instytut Botaniki im. W. Szafera PAN - Poznań: UAM, 1991, ss. 52, k. [10] [tekst równoległy polski i przekład angielski].

Schubert Margot, Herwig Rob. Mieszkamy wśród kwiatów. Tł. Anna Rudowska, Inga Szwedler. Wyd. 5. Warszawa: Państwowe Wydawnictwo Rolnicze i Leśne, 1991, ss. 374, [2] [Wykaz łacińskich nazw roślin i ich odmian, s. 366-[375]; Wykaz polskich nazw roślin, s. 361-365; Dodatek dla szukajacych szybkiej informacji, s. 357-360].

Stidworthy John. Rośliny i zwierzęta. Przeł. Tomasz Umiński. Seria Encyklopedia „Wiedzy i Życia”. Warszawa: Wiedza i Życie, cop. 1991, ss. 48.

\section{2}

Anioł-Kwiatkowska Jadwiga. Rośliny kosmetyczne. Seria Atlas. Warszawa: Wydawnictwa Szkolne i Pedagogiczne, 1992, ss. 247, [1].

Atlas rozmieszczenia geograficznego mchów w Polsce. Z. 8 [= Atlas of the Geographical Distribution of Mosses in Poland]. Red. Ryszard Ochyra, Piotr Szmajda. Oprac. Ryszard Ochyra, Piotr Szmajda, Halina Bednarek-Ochyra. Kraków: Instytut Botaniki im. W. Szafera PAN - Poznań: Uniwersytet im. Adama Mickiewicza, 1992, ss. $77, \mathrm{k}$. [10] [stanowi kontynuację: Atlas rozmieszczenia roślin zarodnikowych $w$ Polsce. Ser. 5, Mchy (Musci). Z. 1-7; tekst równoległy polski i przekład angielski].

Fabiszewski Jerzy. Rośliny Sudetów: atlas. Tablice wykonał Władysław Micek. Wyd. 3. Warszawa: Wydawnictwa Szkolne i Pedagogiczne, 1992, ss. 159, [1], mapa.

Gayówna Delfina. Rośliny łąk: [atlas]. Tablice wykonała Ewa Śliwińska. Rys. kreskowe wykonała Hanna Rembertowicz-Szymborska. Wyd. 6. Warszawa: Wydawnictwa Szkolne i Pedagogiczne, 1992, ss. 158, [2].

Heitz Halina. Jak kwitna i owocuja najpiękniejsze rośliny doniczkowe. Ilustrowany poradnik i encyklopedia dla miłośników roślin doniczkowych. Przekł. Anna Kozłowska. Warszawa: Wiedza i Życie, cop. 1992, ss. 239.

Lánská Dagmar. Jadalne rośliny dziko rosnące. Il. Pavel Žilák. Z jęz. czes. tł. Małgorzata Garbarczyk. Seria Leksykon Przyrody. Warszawa: Polska Oficyna Wydawnicza Delta W-Z, cop. 1992, ss. 223. [1].

Laskowska Wanda. Rośliny borów: [atlas]. Tabl. wykonała z natury Hanna Rembertowicz-Szymborska. Wyd. 5. Warszawa: Wydawnictwa Szkolne i Pedagogiczne, 1992, ss. 146.

Lista roślin zagrożonych $w$ Polsce $=$ List of threatened plants in Poland. Red. Kazimierz Zarzycki, Władysław Wojewoda, Zofia Heinrich. Wyd. 2. Kraków: Instytut Botaniki im. W. Szafera PAN, 1992, ss. 98.

Pajor Wiktor Janusz. Pierwszy polski słownik ziołolecznictwa. Warszawa: Wydawnictwo „Spar”, 1992, ss. 162. 
Piękoś-Mirkowa Halina, Mirek Zbigniew, Mihál Ivor. Kwiaty Tatr: atlas. Kraków: „Karpaty” - Žilina: „Aurum”, 1992, ss. 144 [na s. tyt.: Opracowano wg koncepcji autorskiej publikacji Ivor Mihál - Rudolf Šoltés -Anna Šoltésová „Kvety Tatier”].

Podlewski Jan Kazimierz, Chwalibogowska-Podlewska Alicja. Leki współczesnej terapii. Preparaty roślinne, varia. Oprac. haseł Joanna Dangel et al. Warszawa: Fundacja Büchnera, 1992 ss. XII, 108 [zawiera Słownik łacińsko-polskich i polsko-łacińskich nazw wybranych roślin stosowanych $w$ medycynie oficjalnej i ludowej].

Podhajská Zdenka, Rivola Milan. Wielka encyklopedia roślin. Il. Edward Demartini et al. Z jęz. fr. przeł. Helena Terpińska-Ostrowska. Warszawa: Delta, 1992, ss. 503.

Radwańska-Paryska Zofia. Słownik gwarowy góralskich nazw roślin $z$ Tatr i Podtatrza. Seria Tatry i Podtatrze, Tatrzański Park Narodowy, nr 1. Zakopane: Tatrzański Park Narodowy, 1992, ss. 103.

Sugden Andrew. Ilustrowany słownik botaniczny. Podstawy botaniki z ilustracjami i objaśnieniami. Przeł. Bronisław Wojtuń i Ludwik Żołnierz. Wrocław-WarszawaKraków: Zakład Narodowy im. Ossolińskich - Wydawnictwo, 1992, ss. 200 [1 wyd. ang. Longman York Press, 1984 r.; zawiera Indeks terminów angielskich, Indeks terminów polskich].

Tykač Jan. Rośliny pnące. Il. František Severa. Z fr. tł. Elżbieta Traczewska-Zych. Seria Leksykon Przyrody. Warszawa: Polska Oficyna Wydawnicza BGW, cop. 1992, ss. 224.

Wszechświat i Ziemia, fauna i flora. Przekł. Adam Stepnowski. Konsultacja nauk. Tomasz Hofmokl et al. Red. Rafał Łąkowski. Seria Encyklopedia Mémo Larousse, t. 1. Warszawa: Polska Oficyna Wydawnicza BGW, cop. 1992, ss. 176.

Zając Maria. Index of General Distribution Maps. Vascular Plants of Poland. Seria Polish Botanical Studies. Guidebook Series no 7. Kraków: Polish Academy of Sciences. W. Szafer Institute of Botany, 1992, ss. 76 [zawiera indeks nazw roślin w języku łacińskim].

\section{3}

Altmann Horst. Rośliny trujące i zwierzęta jadowite. Tł. z jęz. niem. Henryk Garbarczyk. Red. wyd. pol. Aleksandra Zduńska. Warszawa: Oficyna Wydawnicza Multico, 1993, ss. 142, [2].

Anioł-Kwiatkowska Jadwiga, Kwiatkowski Stanisław, Berdowski Witold. Rośliny lecznicze: atlas. Warszawa: Wydawnictwo Arkady, 1993, ss. 326, [2].

Anioł-Kwiatkowska Jadwiga. Plants in life of animals. Wrocław: Wydawnictwo Uniwersytetu Wrocławskiego, 1993, ss. 182, [2] [indeksy].

Atlas of the Geographical Distribution of Lichens in Poland. Pt. 1 [= Atlas rozmieszczenia geograficznego porostów w Polsce]. Ed. by Stanisław Cieśliński, Wiesław Fałtynowicz. Elaborated by Urszula Bielczyk, Stanisław Cieśliński, Wiesław Fałtynowicz. Kraków: W. Szafer Institute of Botany of the Polish Academy of Sciences, 1993, ss. 66 [tekst równoległy polski, angielski].

Bremness Lesley. Zioła. Tłum. Krzysztof Spalik. Seria Encyklopedia Kieszonkowa. Warszawa: Muza, 1993, ss. 240.

Chmiel Julian. Flora roślin naczyniowych wschodniej części Pojezierza Gnieźnieńskiego i jej antropogeniczne przeobrażenia w wieku XIX i XX. Cz. 2: Atlas rozmieszczenia 
roślin. Prace Zakładu Taksonomii Roślin Uniwersytetu im. Adama Mickiewicza w Poznaniu, nr 1. Poznań: Sorus, 1993, ss. 212 [mapy].

Drobný Igor, Osvald Zdeněk. Leksykon kwiatów letnich. Tłum. ze słowac. Małgorzata Garbarczyk. Warszawa: Multico, 1993, ss. 96.

Faliński Janusz B., Cieśliński Stanisław, Czyżewska Krystyna. Dynamic-floristic Atlas of Jelonka Reserve and Adjacent Areas. Distribution of Vascular Plant Species, Bryophytes and Lichens on the Abandoned Farmlands During Secondary Succession = Atlas dynamiczno-florystyczny Rezerwatu Jelonka i przyległych obszarów. Rozmieszczenie garunków roślin naczyniowych, mszaków i porostów na nieużytkach porolnych podlegających sukcesji wtórnej. Phytocoenosis, Supplementum Cartographiae Geobotanicae, 3. Warszawa-Białowieża: Białowieska Stacja Geobotaniczna Uniwersytetu Warszawskiego, 1993, ss. 139, [2] [indeks; tekst równoległy polski i przekład angielski].

Grzybek Jan. Ilustrowany słownik farmakobotaniczny. Kraków: Collegium Medicum Uniwersytetu Jagiellońskiego, 1993, ss. 128, [1].

Jackowiak Bogdan. Atlas rozmieszczenia roślin naczyniowych $w$ Poznaniu (=Atlas of distribution of vascular plants in Poznań). Prace Zakładu Taksonomii Roślin Uniwersytetu im. Adama Mickiewicza w Poznaniu, nr 2. Poznań: [s.n.], 1993, ss. 409.

Kardasz Piotr. Rośliny tradycyjne. Seria Kieszonkowa Encyklopedia, 17. Kieszonkowa Encyklopedia Praktycznej Uprawy Roślin Domowych. Katowice: Videograf, 1993, ss. 283, [1].

Masłowski Włodzimierz. Leksykon z anagramami: flora i fauna, seria Leksykon z Anagramami. Warszawa: Contrast, 1993, ss. 196.

Ody Penelope. Wielki zielnik medyczny. Przekł. i konsultacja Halina Piękoś-Mirek, Zbigniew Mirek. Przekł. Barbara Sobiewska. Bielsko-Biała: Wydawnictwo „Debit”, cop. 1993, ss. 192 [na okł.: praktyczny przewodnik po roślinach leczniczych wraz ze sposobami usuwania powszechnie znanych dolegliwości].

Polunin Miriam, Robbins Christopher. Naturalna farmacja [bogato ilustrowana encyklopedia]. Tłum. Izabela Krężelewska, Paweł Oglęcki, Barbara Sudnik-Wójcikowska. Warszawa: Muza, 1993, ss. 144.

Słownik botaniczny. Red. Alicja i Jerzy Szweykowscy. Aut. not encyklopedycznych: Kazimierz Browicz et al. Warszawa: Wiedza Powszechna, 1993, ss. 799, [1], [48] [indeks].

Tymczasowy wykaz współczesnych i kopalnych roślin oraz awifauny Lednickiego Parku Krajobrazowego. Red. Kazimierz Tobolski. Muzeum Pierwszych Piastów na Lednicy. Poznań: Sorus, 1993, ss. 61, [1].

Wielka encyklopedia roślin. Główny wydaw. Christopher Brickell. Tłum. Henryk Chmiel, Małgorzata Świdzińska. Warszawa: Muza, 1993, ss. 608.

\section{4}

Amann Gottfried. Rośliny runa: kieszonkowy atlas najciekawszych grzybów, porostów, mchów, paprotników, traw, ziół rosnących w lasach środkowej Europy wraz z opisem ich budowy i życia. Tł. z jęz. niem. Stefan Łukomski. Seria Flora i Fauna Lasów. Warszawa: Multico Oficyna Wydawnicza, 1994, ss. 416. 
Atlas rozmieszczenia geograficznego mchów w Polsce. Z. 9 [= Atlas of the Geographical Distribution of Mosses in Poland]. Red. Ryszard Ochyra, Piotr Szmajda. Oprac. Halina Bednarek-Ochyra, Ryszard Ochyra, Piotr Szmajda. Kraków: Instytut Botaniki im. W. Szafera PAN, 1994, ss. 69, [10] [tekst równoległy polski i przekład angielski]. Buliński Michał. Systematyczny przegląd flory roślin naczyniowych doliny Wierzycy i dolin jej trzech dopływów. Gdańskie Towarzystwo Naukowe, Wydział II Nauk Medycznych i Biologicznych. Seria Acta Biologica, Sociatas Scientiarum Gedanensis, nr 9. Gdańsk: Gdańskie Towarzystwo Naukowe, cop. 1994, ss. 173, [1], k. złoż. [1].

Fitzsimons Cecilia. Drzewa i lasy: przewodnik po przyrodzie, panorama, słowniczek, poradnik. Przeł. Bartosz Barański i Anna Dorota Kamińska. Seria Mały Atlas Przyrody. Warszawa: Oficyna „Panda”, cop. 1994, ss. 34, k. złoż. [1].

Fitzsimons Cecilia. Wybrzeża morskie: przewodnik po przyrodzie, panorama, słowniczek, poradnik. Przeł. Bartosz Barański i Anna Dorota Kamińska. Seria Mały Atlas Przyrody. Warszawa: Oficyna „Panda”, cop. 1994, ss. 34, k. złoż. [1].

Fitzsimons Cecilia. Rzeki i stawy: przewodnik po przyrodzie, panorama, słowniczek, poradnik. Przeł. Bartosz Barański i Anna Dorota Kamińska. Seria Mały Atlas Przyrody. Warszawa: Oficyna „Panda”, cop. 1994, ss. 34, k. złoż. [1].

Heitz Halina. Jak kwitna i owocują najpiękniejsze rośliny doniczkowe. Ilustrowany poradnik i encyklopedia dla miłośników roślin doniczkowych. Przekł. Anna Kozłowska. Warszawa: Ars Polona, cop. 1994, ss. 239.

Kardasz Piotr. Rośliny hodowane od pestki. Seria Kieszonkowa Encyklopedia, 26. Kieszonkowa Encyklopedia Praktycznej Uprawy Roślin Domowych. Katowice: Videograf, 1994, ss. 227, [1].

Lippert Wolfgang, Podlech Dieter. Kwiaty. Tłum. Anna i Stanisław Kłosowscy. Red. Maria Paciorkiewicz. Seria Encyklopedia Kieszonkowa. Warszawa: Świat Książki, 1994, ss. 253 [Okł.: 400 kolorowych fotografii, 250 rysunków].

Masternak Hanna, Wiech Kazimierz. Jaki to szkodnik, jaka choroba: atlas chorób i szkodników najczęściej występujących na działkach. Biblioteka Działkowca, Polski Związek Działkowców. Krajowa Rada w Warszawie, 52. Warszawa: KR PZD, 1994, ss. 136.

Mautner Uli, Küllenberg Bernd. Przyprawy ziołowe. Seria Kieszonkowa Encyklopedia, 29. Kieszonkowa Encyklopedia Praktycznej Gospodyni. Katowice: Videograf, 1994, ss. 209, [6].

Podlech Dieter. Rośliny lecznicze. Tłum. i oprac. Anna i Stanisław Kłosowscy. Seria Encyklopedia Kieszonkowa. Warszawa: Muza SA, 1994, ss. 253 [315 kolorowych zdjęć z natury].

Rośliny. Tekst: Fabienne Fustec. Współpraca Denis Larpin i Jean-Noel Labat. Il. Catherine Fichaux et al., pod kierunkiem Christiane Beylier. Z jęz. fr. tłum. Elżbieta Traczewska-Zych. Seria Encyklopedia Małolatka. Warszawa: Delta, 1994, ss. 125.

Sarwa Andrzej J. Mała encyklopedia doniczkowych roślin ozdobnych. Tarnów: Karat, 1994, ss. 329.

Sudnik-Wójcikowska Barbara, Moraczewski Ireneusz R. Indices of Synanthropization of Flora in Polish Cities. Seria Plant Cover in Towns. Warszawa: Muzeum i Instytut Zoologii PAN, 1994, s. 93-98. 
Wielka encyklopedia ogrodnictwa. Red. Christopher Brickell. Tłum. i oprac. nauk. Aleksandra Łukaszewska, Ewa Cześnik. Warszawa: Muza, 1994, ss. 648 [na okł. podtyt.: praktyczny, szczegółowy przewodnik po technikach ogrodniczych, planowaniu i pielęgnacji ogrodu, uprawie roślin ozdobnych, sadowniczych i warzywnych].

\section{5}

Atlas of the Marine flora of Southern Spitsbergen [= Atlas flory morskiej potudniowego Spitsbergenu]. Ed. by Romuald Z. Klekowski and Jan Marcin Węsławski. Gdańsk: Polish Academy of Sciences, Institute of Ecology, Institute of Oceanology, 1995, ss. 515, [1] [indeks; tekst równoległy polski, angielski, rosyjski].

Chlebowski Bolesław, Mynett Kazimierz. Kwiaciarstwo. Podręcznik dla techników ogrodniczych i policealnych studiów zawodowych. Wyd. 7 popr. Warszawa: Państwowe Wydawnictwo Rolnicze i Leśne, 1995, ss. 335, [1] [zawiera wykaz łacińskich i polskich nazw rodzajów gatunków roślin].

Flora Polski. Rośliny naczyniowe. T. 15: Obejmuje: Historię oraz Indeksy do tomów serii Flora Polska - Rośliny Naczyniowe Polski i Ziem Ościennych oraz Flora Polski - Rośliny Naczyniowe. Red. Zbigniew Mirek. Aut. Elżbieta Cieślak, Zbigniew Mirek, Wojciech Paul. Seria Flora Polski - rośliny naczyniowe, t. 15. Kraków: Instytut Botaniki - Polska Akademia Nauk, 1995, ss. 262 [zawiera indeksy nazw łacińckich i polskich roślin opisanych $\mathrm{w}$ t. 1-14].

Gibbons Bob, Brough Peter. Atlas roślin Europy Pótnocnej i Środkowej. Przeł. z ang. Barbara Sudnik-Wójcikowska, Izabella Krężelewska. Warszawa: Multico, cop., 1995, ss. 336 [indeks].

Kardasz Piotr. Rośliny domowe końca XX wieku. Seria Kieszonkowa Encyklopedia, 41. Kieszonkowa Encyklopedia Praktycznej Uprawy Roślin Domowych, (41) 14/95. Katowice: Videograf, 1995, ss. 223, [1].

Köhler Piotr. Zielnik Józefa Jundziłła. Seria Polish Botanical Studies. Guidebook Series, no 13. Kraków: Polish Academy of Sciences. W. Szafer Institute of Botany, 1995, ss. 154, k. złoż. [1].

Lippert Wolfgang. Rośliny alpejskie. Red. Maria Paciorkiewicz. Tłum. i oprac. nauk. Anna i Stanisław Kłosowscy. Seria Encyklopedia Kieszonkowa. Warszawa: Muza, cop. 1995, ss. 254, [2].

Lippert / Podlech. Rośliny śródziemnomorskie. Rozpoznawanie i oznaczanie roślin zielnych i krzewów. Seria Encyklopedia kieszonkowa. Warszawa: Musa SA, 1995, ss. 253 [Indeks nazw lacińskich, s. 247-253].

Mirek Zbigniew et al. Vascular plants of Poland. A checklist = Krytyczna lista roślin naczyniowych Polski. Seria Polish Botanical Studies. Guidebook Series no. 15. Kraków: W. Szafer Institute of Botany - Polish Academy of Sciences, 1995, ss. 303 [indeks].

Mirek Zbigniew et al. Collab. Leszek Bernacki et al. Vascular plants of Poland. A chec$k l i s t=$ Krytyczna lista roślin naczyniowych Polski. Seria Polish Botanical Studies. Guidebook Series no. 15. Kraków: W. Szafer Institute of Botany - Polish Academy of Sciences, 1995, ss. $308+$ dyskietka. 
Polakowski Benon. Rośliny chronione: atlas. Warszawa: Wydawnictwo Naukowe PWN, 1995, ss. 185, [3].

Rośliny. Tł. z ang. Małgorzata Garbarczyk. Seria Ilustrowane Słowniki. Warszawa: Arkady, 1995, ss. 62. [2].

Siemińska Jadwiga. Index of Latin Names of Blue-Green Algae Taxa (Cyanophyta) Noted in Poland up to the Year 1980. Seria Polish Botanical Studies. Guidebook Series no 17. Kraków: W. Szafer Institute of Botany, Polish Academy of Science, 1995, ss. 51 [tekst równoległy polski, angielski]

Sugden Andrew. Ilustrowany słownik botaniczny. Podstawy botaniki z ilustracjami i objaśnieniami. Tł. Bronisław Wojtuń i Ludwik Żołnierz. Wrocław: Zakład Narodowy im. Ossolińskich - Wydawnictwo, 1995, ss. 200 [zawiera Indeks terminów angielskich, Indeks terminów polskich].

\section{6}

Cisowski Wojciech et al. Atlas do ćwiczeń morfologiczno-anatomicznych z farmakognozji. Akademia Medyczna w Gdańsku. Wyd. 2 popr. i uzup. Gdańsk: Akademia Medyczna. ss. VIII, 67 [uzupełnienie do Skryptu do ćwiczeń morfologiczno-anatomicznych $z$ farmakognozji].

Coombes Allen J. Drzewa. Ilustrowany przewodnik obejmujący ponad 500 gatunków drzew z całego świata. Fot. Matthew Ward. Tł. z ang. Izabela Krężelewska, Barbara Sudnik-Wójcikowska. Seria Kolekcjoner - Wiedza i Życie. Warszawa: Wiedza i Życie, cop. 1996, ss. 320 [indeks].

Grau Jürke, Jung Reinhard, Münker Bertram. Zioła i owoce leśne. Przekł. [z niem.] i adaptacja Władysław Matuszkiewicz. Seria Leksykon Przyrodniczy. Warszawa: GeoCenter, 1996, ss. 287.

Greenaway Theresa. Drzewa. Tł. z ang. Izabela Krążlewska, Barbara Sudnik-Wójcikowska. Seria Mini Encyklopedia. Warszawa: Muza, 1996, ss. 159, [1] [indeks].

Konraś Jan, Medwecka-Konraś Anna, Towpasz Krystyna. Rośliny naczyniowe Pogórza Ciężkowickiego (Karpaty Zachodnie) = Vascular plants of Pogórze Ciężkowickie (Western Carpathians). Zeszyty Naukowe Uniwersytetu Jagiellońskiego. Prace Botaniczne, z. 28. Kraków: Instytut Botaniki UJ, 1996, ss. 170 [spisy].

Larousse encyklopedia przyrody. Flora i fauna. Tłum. z jęz. fr. i konsult. nauk. Anna Jerzmańska et al. Wrocław: Panteon, cop. 1996, ss. XXIV, 370, tabl. [56].

Přibyl Jan. Ozdobne rośliny pokojowe. Il. Zdeněk Berger. Z jęz. franc. tł. Elżbieta Traczewska-Zych. Seria Leksykon Przyrody. Warszawa: Oficyna Wydawnicza Delta W-Z, [1996 ?], ss. 223, [1] [zawiera Indeks nazw polskich i łacińskich].

Rejewski Marian. Pochodzenie łacińskich nazw roślin polskich. Przewodnik botaniczny. Warszawa: Książka i Wiedza, cop., 1996, ss. 170, [2].

Słownik botaniczny. Red. Alicja i Jerzy Szweykowscy. Aut. not encyklopedycznych: Kazimierz Browicz et al. Wyd. 1, dodruk. Warszawa: Wiedza Powszechna, 1996, ss. 799, [1], [48] [indeks].

Sugden Andrew. Ilustrowany słownik botaniczny: podstawy botaniki z ilustracjami i objaśnieniami. Przeł. Bronisław Wojtuń i Ludwik Żołnierz. Wrocław-WarszawaKraków: Zakład Narodowy im. Ossolińskich - Wydawnictwo, 1996, ss. 200 [zawiera Indeks terminów angielskich, s. 180-189, Indeks terminów polskich, s. 190-200]. 
Urbisz Andrzej. Flora naczyniowa Płaskowyżu Rybnickiego na tle antropogenicznych przemian tego obszaru. Park Krajobrazowy „Cysterskie Kompozycje Krajobrazowe Rud Wielkich”. Seria Scripta Rudensia 6. Rudy Wielkie: Dyrekcja Parku Krajobrazowego „Cysterskie Kompozycje Krajobrazowe Rud Wielkich”, 1996, ss. 173, [1], s. tabl. [4].

Wielka encyklopedia roślin. Red. Christopher Brickell. Tłum. Henryk Chmiel, Małgorzata Świdzińska. Red. wersji pol. Bożena Zasieczna. Warszawa: Świat Książki, 1996, ss. 640.

Wielka encyklopedia roślin. Red. Christopher Brickell. Tłum. Henryk Chmiel, Małgorzata Świdzińska. The Royal Horticultural Society. Wyd. 2 nowe. Warszawa: Muza, 1996, ss. 640.

Zakładanie ogrodu. Tłum. Małgorzata Świdzińska. Red. Bożena Zasieczna. Seria Encyklopedia Kieszonkowa. Warszawa: Muza, 1996, ss. 224.

\section{7}

Amann Gottfried. Rośliny runa: kieszonkowy atlas najciekawszych grzybów, porostów, mchów, paprotników, traw i ziót rosnących w lasach środkowej Europy wraz z opisem ich budowy i życia. Tł. z jęz. niem. Stefan Łukomski. Seria Flora i Fauna Lasów. Warszawa: Multico, 1997, ss. 416.

Atlas rozmieszczenia roślin naczyniowych chronionych $w$ Polsce $[=$ Distribution Atlas of Vascular Plants Protected in Poland]. Red. Adam Zając, Maria Zając. Aut. opracowań regionalnych Marian Ciaciura et al. Kraków: Pracownia Chorologii Komputerowej Instytutu Botaniki Uniwersytetu Jagiellońskiego, 1997, ss. 99, [1] [przedmowa, wstęp i omówienie gatunków również angielskich].

Kupidłowska Ewa, Sudnik-Wójcikowska Barbara, Słownik Szkolny. Terminy i pojęcia botaniczne. Seria Słownik Szkolny. Warszawa: Wydawnictwa Szkolne i Pedagogiczne, 1997, ss. 254, [2].

McIntyre Anne. Apteczka babuni w pospolitych dolegliwościach. Z ang. przeł. Joanna Figlewska. Warszawa: Świat Książki - Delta, 1997, ss. 95 [spisy].

Ohnesorge Gerd, Scheiba Bernd, Uhlenhaut Karl. Ślady i tropy zwierząt: kieszonkowy atlas. Tł. z jęz. niem. Barbara Żybura. Seria Flora i Fauna Lasów. Warszawa: Multico, cop. 1997, ss. 352.

Piotrowska Hanna, Żukowski Waldemar, Jackowiak Bogdan. Rośliny naczyniowe Słowińskiego Parku Narodowego. Prace Zakładu Taksonomii Roślin Uniwersytetu im. Adama Mickiewicza w Poznaniu, nr 6. Poznań: Bogucki - Wydawnictwo Naukowe, 1997, ss. 216, mapy [spisy].

Podbielkowski Zbigniew. Szata roślinna Ziemi. Seria Wielka encyklopedia geografii świata, t. 7. Poznań: Kurpisz, cop. 1997, ss. VI, [2], 359.

Podlech Dieter. Rośliny lecznicze. Tłum. i oprac.nauk. Anna Kłosowska, Stanisław Kłosowski. Seria Encyklopedia Kieszonkowa. Wyd. 3. Warszawa: Muza, 1997, ss. 254.

Rostański Krzysztof et al. Drzewa i krzewy Katowic wraz z kluczem do ich oznaczania. Seria Flora i Fauna Katowic. Wyd. 2. Krzeszowice: Planta: na zlec. Zarządu Miasta Katowice, 1997, ss. 64. 


\section{8}

Atlas rozmieszczenia roślin naczyniowych w woj. krakowskim. Gatunki prawnie chronione, ginace, narażone i rzadkie = Distribution Atlas of Vascular Plants in Cracow Province. Legally Protected, Endangered, Vulnerable and Rare Species. Red. Maria Zając i Adam Zając. Aut. Wacław Bartoszek et al. Kraków: Pracownia Chorologii Komputerowej Instytutu Botaniki Uniwersytetu Jagiellońskiego, 1998, ss. 134 [tekst równoległy polski, angielski].

Dajdok Zygmunt et al. Atlas rozmieszczenia roślin naczyniowych prawnie chronionych $w$ województwie opolskim = Distribution Atlas of Legally Protected Vascular Plants in Opole Province. Opole: Wydawnictwo Uniwersytetu Opolskiego, 1998, ss. 278, [1] [tekst równoległy polski, angielski].

Dajdok Zygmunt et al. Atlas rozmieszczenia rzadkich roślin naczyniowych w województwie opolskim = Distribution Atlas of Rare Vascular Plants in Opole Province. Opole: Wydawnictwo Uniwersytetu Opolskiego, 1998, ss. 204, [1] [tekst równoległy polski, angielski].

Fiedorow Zofia, Weber Zbigniew. Choroby roślin uprawnych. Poznań: Wydawnictwo Medix Plus H. Mikołajczak, cop. 1998, ss. 171, [1] [atlas zawiera wykaz fungicydów stosowanych do zwalczania chorób].

Katalog zbiorów zielnika Muzeum Przyrodniczego Uniwersytetu Wrocławskiego = Catalogus plantarum, quae in Herbario Musei Historiae Naturalis Universitatis Wratislaviensis asservantur. 16, Bryophyta. Cz. 5. Oprac. Wanda Stojanowska. Wrocław: Wydawnictwo Uniwersytetu Warszawskiego, 1998, ss. 15.

Katalog zbiorów zielnika Muzeum Przyrodniczego Uniwersytetu Wrocławskiego = Catalogus plantarum, quae in Herbario Musei Historiae Naturalis Universitatis Wratislaviensis asservantur. 15, Myxophyta. Cz. 2. Oprac. Wanda Stojanowska. Wrocław: Wydawnictwo Uniwersytetu Warszawskiego, 1998, ss. 23.

Krause Joanna, Lisiecka Anna. Kwiaty jednoroczne: [atlas]. Poznań: Medix Plus, cop. 1998, ss. 162, [6] [literatura uzupełniająca w nauczaniu przedmiotu „rośliny ozdobne" dla nauczycieli i uczniów szkół ogrodniczych oraz studentów szkół wyższych].

Lippert / Podlech. Rośliny śródziemnomorskie. Rozpoznawanie i oznaczanie roślin zielnych i krzewów. Seria Encyklopedia Kieszonkowa. Wyd. 2. Warszawa: Muza SA, 1998, ss. 253 [Indeks nazw łacińskich, s. 247-253].

Podlech Dieter. Rośliny lecznicze. Tłum. i oprac. nauk. Anna i Stanisław Kłosowscy. Seria Encyklopedia Kieszonkowa. Wyd. 4. Warszawa: Muza SA, 1998, ss. 253.

Mandecka Maria, Mirek Zbigniew, Paul Wojciech. Polish Exsiccata of Vascular Plants. Index of Taxa and Bibliography $=$ Wydawnictwa zielnikowe Polski. Seria Polish Botanical Studies. Guidebook Series no 19. Kraków: W. Szafer Inst. of Botany. Polish Academy of Sciences, cop., 1998, ss. 219.

Münker Bertram. Kwiaty polne i leśne. Przekł. z niem. Jadwiga Kozłowska. Seria Leksykon Przyrodniczy. Warszawa: Świat Książki, 1998, ss. 288.

Pajor Wiktor Janusz. Mała encyklopedia przypraw, smaków i ziołolecznictwa. Kraków: Wydawnictwo Tempus Plus, 1998, ss. 206.

Pick Józef. W świecie Biblii - flora. Niemi świadkowie chwały Boga. Leksykon roślin w Biblii. Pelpin: Bernardinum, 1998, ss. 183. 
Reichholf Josef. Tereny wilgotne. Przekł. Barbara Ostrowska. Seria Leksykon Przyrodniczy. Warszawa: Świat Książki, 1998, ss. 222.

Rogowska Ewa. Kaszubskie nazwy roślin uprawnych. Gdańsk: Wydawnictwo Uniwersytetu Gdańskiego, 1998, ss. 195 [s. 11-152: Słownik nazw; zawiera 586 nazw 132 roślin wraz z odpowiednikami łacińskimi i niemieckimi; Indeks kaszubskich nazw roślin, Indeks polskich nazw roślin].

Rośliny kwiatowe. 1. Red. Anna Masternak. Tłum. Marian Rejewski, Tomasz Waszak. Seria Wielka Encyklopedia Przyrody. Warszawa: Muza, 1998, ss. 496.

Rośliny kwiatowe. 2. Red. Małgorzata Świdzińska. Tłum. Waldemar Fortuna, Dorota Metera, Tomasz Waszak. Seria Wielka Encyklopedia Przyrody. Warszawa: Muza, 1998, ss. 568.

\section{9}

Atlas of the Geographical Distribution of Lichens in Poland, Pt. 2 [= Atlas rozmieszczenia geograficznego porostów w Polsce]. Ed. by Stanisław Cieśliński, Wiesław Fałtynowicz. Kraków: W. Szafer Institute of Botany of the Polish Academy of Sciences, 1999, ss. 58, [5] [tekst równoległy angielski, polski].

Bown Deni. Wielka encyklopedia ziół. Tłum. Małgorzata Świdzińska. Warszawa: Muza, 1999, ss. 423, [1] [na okł.: Ponad 1000 roślin, 1500 fotografii. Rzetelne źródło informacji].

Chinery Michael. Rośliny i zwierzęta w ogrodzie. Tłum. i konsultacja nauk. Grażyna Winiarska, Ewa Siedlar, Barbara Sudnik-Wójcikowska. Seria Encyklopedia Kieszonkowa. Warszawa: Muza, 1999, ss. 250, [6].

Coombes Allen J. Drzewa. Ilustrowany przewodnik obejmujący ponad 500 gatunków drzew z całego świata. Fot. Matthew Ward. Tł. z ang. Izabela Krężelewska, Barbara Sudnik-Wójcikowska. Seria Kolekcjoner - Wiedza i Życie, Warszawa: Wiedza i Życie, cop. 1999, ss. 320 [indeks].

Encyklopedia przyrody. Tłum. Bartosz Baranowski et al. Red. Ewa Dedo, Zofia Siewak-Sojka. [Bielsko-Biała]: Pascal, cop. 1999, ss. 304, mapy.

Flora A-Z. Wybór i oprac. haseł Jerzy Marchewka. Biblioteczka Szaradzisty, t. 5. Toruń: Wydawnictwo Teresa i Jerzy Marchewka, 1999, ss. 204.

Masternak Hanna. Zagrażają roślinom $w$ domu, na balkonie, $w$ ogródku: atlas chorób i szkodników. Warszawa: Oficyna Wydawnicza „Hoża”, 1999, ss. 156, [2].

Mikołajczyk Krystyna, Wierzbicki Adam. Zioła źródłem zdrowia [leksykon]. Warszawa: Oficyna Wydawniczo-Poligraficzna „Adam”, 1999, ss. 448, XVI.

Nawara Zbigniew, Sendecki Paweł. Rośliny chronione w Polsce. Seria Encyklopedia Kieszonkowa. Warszawa: Muza, 1999, ss. 207, [1].

Nowak Teresa. Atlas rozmieszczenia roślin naczyniowych na terenie wschodniej częsci Garbu Tarnogórskiego (Wyżyna Śląska (= Atlas of vascular plants distribution of the eastern part of Tarnogórski Hump (Silesian Upland)). Seria Materiały, Opracowania, Centrum Dziedzictwa Przyrody Górnego Śląsk, t. 2. Katowice: Centrum Dziedzictwa Przyrody Górnego Śląska, 1999, ss. 103.

Ochyra Ryszard, Cisło Grażyna. Mchy w zielniku Tytusa Chałubińskiego w Muzeum Tatrzańskim $w$ Zakopanem $=$ The moss herbarium of Tytus Chatubinski in the Tatra Museum in Zakopane. Seria Polish Botanical Studies. Guidebook Series, no 22. 
Zakopane: Muzeum Tatrzańskie im. Dra Tytusa Chałubińskiego - Kraków: Polska Akademia Nauk. Instytut Botaniki im. W. Szafera, 1999, ss. 178.

Ody Penelope. Wielki zielnik medyczny. Przekł. i konsultacja Halina Piękoś-Mirek, Zbigniew Mirek. Przekł. Barbara Sobiewska. Bielsko-Biała: Wydawnictwo „Debit”, cop. 1999, ss. 192 [na okł. podtyt.: praktyczny przewodnik po roślinach leczniczych wraz ze sposobami usuwania powszechnie znanych dolegliwości].

Reichholf Josef. Morza i wybrzeża: flora, fauna i zagrożenia ekologiczne. Przekł. z niem. Anna Ambroziak. Seria Leksykon Przyrodniczy. Warszawa: Świat Książki, cop. 1999, ss. 222, [1].

Reichholf Josef. Żyja wśród nas: fauna i flora osiedli ludzkich. Przekł. z niem. Zbigniew Woliński. Seria Leksykon Przyrodniczy. Warszawa: Świat Książki, cop. 1999, ss. 222, [1].

Sugden Andrew. Ilustrowany słownik botaniczny: podstawy botaniki z ilustracjami i objaśnieniami. Tł. Bronisław Wojtuń i Ludwik Żołnierz. Dodruk Wrocław-Warszawa-Kraków: Zakład narodowy im. Ossilińskich - Wydawnictwo, 1999, ss. 200 [zawiera Indeks terminów angielskich, s. 180-189, Indeks terminów polskich, s. 190200].

Tokarska-Guzik Barbara. Atlas rozmieszczenia roślin naczyniowych w Jaworznie (Wyżyna Ślaska) = Atlas of vascular plants distribution in Jaworzno town (Silesian Upland). Seria Prace Botaniczne, Instytut Botaniki Uniwersytetu Jagiellońskiego, t. 34. Kraków: Instytut Botaniki Uniwersytetu Jagiellońskiego, 1999, ss. 292.

Waźbińska Jadwiga, Puczel Urszula. Ćwiczenia z roślin ozdobnych. Cz. 1: Rośliny jednoroczne i dwuletnie. Uniwersytet Warmińsko-Mazurski w Olsztynie (Akademia Rolniczo-Techniczna im. Michała Oczapowskiego w Olsztynie). Olsztyn: Wydawnictwo Akademii Rolniczo-Technicznej im. Michała Oczapowskiego, 1999, ss. 118, [2] [indeksy].

Wielka encyklopedia roślin ogrodowych od A do Z. Red. wyd. Christopher Brickell. Tłum.: Ewa Bieńkowska-Mochtak et al. Warszawa: Muza, 1999, ss. 1080, [2] [Na okł.: Ponad 15000 roślin ozdobnych, 6000 fotografii. Rzetelne źródło informacji].

\section{0}

Dubiel Eugeniusz, Gawroński Stefan, Grzegorzek Piotr. Atlas roślin chronionych, rzadkich i ginących gminy Chrzanów. Chrzanów: Urząd Miejski, 2000, ss. 107.

Encyklopedia zielarstwa i ziołolecznictwa. Red. Halina Strzelecka i Józef Kowalski. Aut. Waldemar Buchwald et al. Warszawa: Wydawnictwo Naukowe PWN, 2000, ss. 645 [Książka wydana dzięki pomocy finansowej Poznańskich Zakładów Zielarskich HERBAPOL S.A.].

Mirkowie Halina i Zbigniew. Rośliny gór polskich. Fot. Ewa i Marek Zarębscy. Seria Encyklopedia Kieszonkowa. Warszawa: Muza, 2000, ss. 247, mapy.

Nowak Barbara. Leksykon roślin ozdobnych i użytkowych. Fot. Tadeusz Mazurek. Warszawa: Państwowe Wydawnictwo Wiedza Powszechna, 2000, ss. 294, [1].

Pastok Paweł. Kompendium leków naturalnych: zioła pojedyncze, mieszanki ziołowe, wyciagi ziołowe, leki ziołowe złożone, leki homeopatyczne. Seria Biblioteka „Lek w Polsce", Warszawa: Medyk, 2000, ss. [6], XIV, [2], 466. 
Phillips Sue et al. Encyklopedia roślin ogrodowych w pojemnikach [zastosowanie skrzynek, doniczek, korytek, koszyków. Fot. Neil Sutherland. Przekł. z jęz. ang. Elżbieta Traczewska-Zych. Warszawa: Oficyna Wydawnicza Delta W-Z, [ca 2000], ss. 348.

Rośliny pokojowe. Ilustrowana encyklopedia. Tekst Anna Skalická. Fot. Rudolf Šubík. $\mathrm{Z}$ jęz. fr. przeł. Helena Terpińska-Ostrowska i Elżbieta Traczewska-Zych. Warszawa: Delta, [ca 2000], ss. 255 [278 ilustracji].

Zielnikx. Jana Twardowskiego. Zdj. Robert Baś et al. Warszawa: Bronowski Studio, cop. 2000, ss. 63, [1].

\section{1}

Atlas rozmieszczenia roślin naczyniowych $w$ Polsce $=$ Distribution Atlas of Vascular Plants in Poland. Red. Adam Zając, Maria Zając. Aut. Edward Bróż et al. Przedm. Romuald Olaczek. Przeł. Roman Tertil. Kraków: nakł. Pracowni Chorologii Komputerowej Instytutu Botaniki Uniwersytetu Jagiellońskiego, 2001, ss. XII, 714, [2] [tekst równoległy polski, angielski].

Atlas skamieniałości przewodnich i charakterystycznych. Cz. 1c. Z. 2: Młodszy paleozoik, karbon, flora. Red. nauk. Maria Pajchlowa. Aut. Bolesław Brzyski et al. Państwowy Instytut Geologiczny. Seria Budowa geologiczna Polski, t. 3. Warszawa: Państwowy Instytut Geologiczny, 2001, ss. [5] 534-928, ss. 182-310, tabl.

Atlas skamieniałości przewodnich i charakterystycznych. Cz. 1c. Z. 3: Młodszy paleozo$i k$, perm. Red. nauk. Maria Pajchlowa i Ryszard Wagner. Aut. Andrzej Boczarowski et al. Państwowy Instytut Geologiczny. Seria Budowa geologiczna Polski, t. 3. Warszawa: Państwowy Instytut Geologiczny, 2001, ss. 224, ss. tabl. 72, k. złoż. [1], mapy.

Cabała Stanisław et al. Przyroda Międzyrzecza Warty i Widawki. Katowice: Wydawnictwo Uniwersytetu Śląskiego, 2001, ss. 299, [1], mapa [zawiera spisy].

Del Moro Maria Antonietta. Rośliny. Tłum. Dagmara Spólniak. Seria Na ścieżkach wiedzy: encyklopedia edukacyjna. Red. serii pol. Anna Kędziorek, 10. Warszawa: Dom Wydawniczy Bellona, cop. 2001, ss. 94.

Drobný Igor, Osvald Zdeněk. Leksykon kwiatów letnich. Tłum. z jęz. słowac. Małgorzata Garbarczyk. Warszawa: Klub dla Ciebie, 2001, ss. 96.

Encyklopedia przyrody. Fauna i flora Europy. Tłum. Marta Chudzicka et al. Wyd. 2. Warszawa: Muza 2001, ss. 384, mapy.

Encyklopedia roślin ogrodowych od A do Z. Projekt i red. Ernö Zelter. Aut. Andreas Bärtels et al. Z niem. przeł. Krzysztof Żak. Warszawa: Świat Książki - Grupa Wydawnicza Bertelsmann, 2001, ss. 1149, [1].

Faliński Janusz B. Atlas fitofenologiczny zbiorowisk i gatunków leśnych Białowieskiego Parku Narodowego $=$ Phytophenological Atlas of the Forest Communities and Species of Białowieża National Park. Phytocoenosis, Archivum Geobotanicum, 8. Białowieska Stacja Geobotaniczna Uniwersytetu Warszawskiego. Warszawa-Białowieża 2001, ss. 176, k. [1] [indeks; tekst równoległy polski, angielski].

Flora: anagramy, homonimy, synonimy. Wybór i oprac. haseł Jerzy Marchewka. Indeks Teresa Marchewka. Toruń: Wydawnictwo Teresa i Jerzy Marchewka, cop. 2001, ss. 64.

Jędrzejko Krzysztof. Medicinal Plants and Herbal Materials in Use in Poland. A Check List $=$ Wykaz roślin i surowców leczniczych stosowanych $w$ Polsce. Katowice: Śląska 
Akademia Medyczna, cop., 2001, ss. 393 [indeks; tekst równoległy polski, angielski].

Kucharczyk Marek. Distribution atlas of vascular plants in the Middle Vistula river valley. Lublin: Maria Curie-Skłodowska University Press, 2001, ss. 395.

Kwiaty. Rozpoznać - podziwiać - chronić. Tekst Robert Hofrichter. Konsultacja niem. Bruno P. Kremer. Tłum. i adapt. Ewa Turyn, Barbara Urbańska. Seria Praktyczny Leksykon Przyrody. Warszawa: Klub dla Ciebie, 2001, ss. 191, [1].

Lepert Rajmund, Turyn Ewa. Słownik roślin i zwierząt. Nazewnictwo polskie, łacińskie, francuskie. Wyd. 1. Warszawa: Wiedza Powszechna, 2001, ss. 530 [40 000 nazw roślin i zwierząt; indeksy: polski - 14000 nazw, francuski - 14000 nazw, łaciński - 12000 terminów].

Olech Maria. Annotated checklist of Antarctic lichens and licheniocolous fungi. Institute of Botany of the Jagiellonian University. Kraków 2001, ss. 145.

Podręczny leksykon przyrody polskiej. Tekst i il. Robert Dzwonkowski. Warszawa: Wydawnictwo RTW, 2001, ss. 274, [4] [tyt. okł.: Leksykon - przyroda polska].

Rośliny Alp. Rozpoznać - podziwiać - chronić. Tekst: Wolfgang Hensel. Konsultacja niem. Bruno P. Kremer. Tłum. i adapt. Barbara Zych. Seria Praktyczny Leksykon Przyrody. Warszawa: Klub dla Ciebie, 2001, ss. 191. [1].

Rośliny i zwierzęta. Przekł. z jęz. ang. Piotr Nowak. Red. wyd. pol. Beata Maria Mizerska. Seria Nowy leksykon szkolny. Warszawa: Delta - Hubert, [ca 2001], ss. 127, [1].

Rośliny i zwierzęta. Przekł. z jęz. fr. Elżbieta Traczewska-Zych, Małgorzata i Izabela Szmurło. Red. Donata Łuszczewska. Seria Encyklopedia Szkolna Larousse. Warszawa: Delta W-Z, [ca 2001], ss. 103, [1].

Sarwa Andrzej. Wielki leksykon roślin leczniczych. Warszawa: Książka i Wiedza, cop. 2001, ss. 444, [1].

Urbisz Alina. Atlas rozmieszczenia roślin naczyniowych południowo-zachodniej części Wyżyny Katowickiej. Prace Naukowe Uniwersytetu Śląskiego w Katowicach, nr 1944. Katowice: Wydawnictwo Uniwersytetu Śląskiego, 2001, ss. 234, [1], [8].

Waźbińska Jadwiga, Puczel Urszula. Ćwiczenia z roślin ozdobnych. Cz. 2: Byliny. Olsztyn: Wydawnictwo Uniwersytetu Warmińsko-Mazurskiego, 2001, ss. 195 [skorowidz dotyczący bylin].

Waźbińska Jadwiga, Puczel Urszula. Ćwiczenia z roślin ozdobnych. Cz. 3: Rośliny doniczkowe. Olsztyn: Wydawnictwo Uniwersytetu Warmińsko-Mazurskiego, 2001, ss. 133 [skorowidz dotyczący doniczkowych roślin ozdobnych].

Wielka encyklopedia roślin. Red. nacz. Christopher Brickell. Tłum. Henryk Chmiel, Małgorzata Świdzińska. Red. wersji pol. Bożena Zasieczna. Nowe [3] wyd. Warszawa: Muza, 2001, ss. 640.

Zioła. Rozpoznać - podziwiać - chronić. Tekst Wolfgang Hensel. Konsultacja nauk. Bruno P. Kremer. Przekł. i adaptacja Ewa Turyn i Barbara Urbańska. Seria Praktyczny Leksykon Przyrody. Warszawa: Klub dla Ciebie, 2001, ss. 191. [1] [230 gatunków ziół na 400 kolorowych zdjęciach].

\section{2}

Adamowski Wojciech, Ljudmila Dvorak, Ramanjuk Igar. Atlas of Alien Woody Species of the Białowieża Primaeval Forest = Atlas obcych gatunków drzewiastych Puszczy 
Białowieskiej = Атлас іншаземных дрэвавых відаў Белавежскай Пушчы. Phytocoenosis, Supplementum Cartographiae Geobotanicae, 14. Białowieska Stacja Geobotaniczna Uniwersytetu Warszawskiego. Warszawa-Białowieża 2002, ss. 303, [12] [indeks; tekst w językach: angielskim, polskim, białoruskim].

Anioł-Kwiatkowska Jadwiga et al. Czerwona ksiega roślin województwa opolskiego: rośliny naczyniowe, wymarłe, zagrożone i rzadkie. Red. Arkadiusz Nowak, Krzysztof Spałek. Opolskie Towarzystwo Przyjaciół Nauk. Seria Wydawnicza „Przyroda Opolska”. Opole: Śląskie Wydawncitwo „Adan”, 2002, ss. 158, [2] [indeksy].

Atlas of the Geographical Distribution of Lichens in Poland. Pt. $3=$ Atlas rozmieszczenia geograficznego porostów w Polsce. Ed. by Urszula Bielczyk, Stanisław Cieśliński, Wiesław Fałtynowicz. Kraków: W. Szafer Institute of Botany of the Polish Academy of Sciences, 2002, ss. 114 [tekst równoległy polski, angielski].

Czerwona księga roślin województwa opolskiego. Rośliny naczyniowe, wymarłe, zagrożone i rzadkie. Red. Arkadiusz Nowak, Krzysztof Spałek. Aut. Jadwiga Anioł-Kwiatkowska et al. Opolskie Towarzystwo Przyjaciół Nauk. Seria Wydawnicza „Przyroda Opolska”. Opole: Śląskie Wydawnictwo „Adan”, 2002, ss. 158, [2] [indeksy].

Della Beffa Maria Teresa. Rośliny górskie. Z niem. przeł. Jadwiga Kozłowska. Il. Annalisa i Marina Durante. Seria Podręczny Leksykon Przyrodniczy. Warszawa: Horyzont - Grupa Wydawnicza Bertelsmann Media, 2002, ss. 223.

Głowkin Borys N., Minin Aleksander A. Atlas żywej przyrody. Oprac. wersji pol. Grzegorz Wójcik. Il. A. A. Borysow et al. Zielona Góra: Wydawnictwo Elżbieta Jarmołkiewicz, cop. 2002, ss. 71, [1], mapy.

Griffith Henry Winter. Wielki leksykon witamin, ziót, składników mineralnych i suplementów. Przekł. Stanisława Procyk. Seria Encyklopedyczne Poradniki Medyczne. Warszawa: Amber, cop. 2002, ss. 558, [2].

Krause Joanna. Kwiaty cebulowe. Warszawa: Wydawnictwo „Działkowiec”, cop. 2002, ss. 175, [1], fot. [Skorowidz nazw polskich].

Mirek Zbigniew et al. Flowering plants and pteridophytes of Poland. A checklist $=$ Krytyczna lista roślin naczyniowych Polski. Seria Biodiversity of Poland = Różnorodność biologiczna Polski, vol. 1, Kraków: W. Szafer Institut of Botany, Polish Academy of Sciences, 2002, ss. 442 [lista gatunków równolegle w języku łacińskim i polskim].

Motyka-Zgłobicka Maria, Zgłobicki Wojciech. Atlas typów nomenklatorycznych rodziny Lecanoraceae $z$ herbarium $L B L-L=$ Atlas of Nomenclature Types of Lecanoraceae Family, Herbarium LBL - L. Seria Porosty (Lichenes), Rodzina Lecanoraceae, J. Motyka, t. 5. Lublin: Uniwersytetu Marii Curie-Skłodowskiej, 2002, ss. [86] [tekst angielski i polski, indeks i podpisy ilustracji w języku łacińskim].

Poljsko-srpskohrvatski rečnik biljaka sa srpskohrvatsko-poljskim indeksom $=$ Polsko-serbskochorwacki słownik roślin z indeksem serbskochorwacko-polskim. Ułożył Dušan-Vladislav Paždjerski. Gdańsk: Wydawnictwo GP Art. Zaspa, 2002, ss. 194.

Rohwer Jens G. Atlas roślin tropikalnych. Z niem. przeł. Małgorzata Świdzińska. Warszawa: Horyzont - Grupa Wydawnicza Bertelsmann Media, 2002, ss. 285, [2].

Rośliny Wzgórz Dalkowskich. Cz. 1 = Plantae Wzgórza Dalkowskie. P. 1. Oprac. Edward Kozioł i Halina Charytonowicz. Uniwersytet Wrocławski. Muzeum Przyrodnicze. 
Seria Zielnik roślin naczyniowych Śląska, z. 58. Wrocław: Uniwersytet Wrocławski, 2002, ss. 10.

Twardowski Jan. Zielnik [68 roślin i ziół o wielkim działaniu wraz z opisem]. Izabelin-Warszawa: Rosikon Press, cop. 2002, ss. 164, [4].

Waźbińska Jadwiga, Kawecki Zdzisław. Drzewa i krzewy iglaste. Olsztyn: Wydawnictwo Uniwersytetu Warmińsko-Mazurskiego, 2002, ss. 152 [indeks].

Zarzycki Kazimierz et al. Ecological indicator values of vascular plants of Poland = Ekologiczne liczby wskaźnikowe roślin naczyniowych Polski. Seria Biodiversity of Poland = Różnorodność biologiczna Polski, vol. 2. Kraków: W. Szafer Institute of Botany, Polish Academy of Sciences, 2002, ss. 183, k. luź. [1] [Skorowidz łacińsko-polski i polsko-łaciński].

\section{3}

Anioł-Kwiatkowska Jadwiga. Wielojęzyczny słownik florystyczny polsko-łacińsko-angielsko-francusko-niemiecki. Acta Universitatis Wratislaviensis, nr 2577. Wrocław: Wydawnictwo Uniwersytetu Wrocławskiego, 2003, ss. 691, [2] [na okł.: Słownik zawiera ponad 6000 haset w językach: polskim, łacińskim, angielskim, francuskim i niemieckim].

Cieśliński Stanisław. Atlas rozmieszczenia porostów (Lichenes) w Polsce Północno-Wschodniej = Distribution Atlas of Lichens (Lichenes) in North-Eastern Poland. Phytocoenosis, Supplementum Cartographiae Geobotanicae, 15. Warszawa-Białowieża: Białowieska Stacja Geobotaniczna Uniwersytetu Warszawskiego, 2003, ss. 430 [indeks], [napisy pod ilustracjami polskie, angielskie].

Drobný Igor, Osvald Zdeněk. Leksykon kwiatów letnich. Tł. z jęz. słowac. Małgorzata Garbarczyk. Warszawa: Klub dla Ciebie, 2003, ss. 96.

Drozdowicz Anna et al. Myxomycetes of Poland - a checklist = Krytyczna lista śluzowców Polski. Seria Biodiversity of Poland, vol. 10. Kraków: W. Szafer Institute of Botany, Polish Academy of Sciences, 2003, ss. 103, [1] [nazwy śluzowców łacińskie i polskie; tekst równoległy angielski i polski].

Dubiel Eugeniusz. Rośliny naczyniowe Puszczy Niepołomickiej = Vascular plants of the Niepołomice Forest. Prace Botaniczne, Instytut Botaniki Uniwersytetu Jagiellońskiego, 37. Kraków: Instytut Botaniki Uniwersytetu Jagiellońskiego, 2003, ss. 313.

Fałtynowicz Wiesław. The lichens, lichenicolous and allied fungi of Poland - an annotated checklist $=$ Krytyczna lista porostów i grzybów naporostowych Polski, seria Biodiversity of Poland = Różnorodność Biologiczna Polski, vol. 6. Kraków: W. Szafer Institute of Botany. Polish Academy of Sciences, 2003, ss. 435 [indeksy].

Lewkowicz-Mosiej Teresa. Leksykon roślin leczniczych. Warszawa: Świat Książki, cop. 2003, ss. 368, ss. tabl. [32].

Lista gatunków roślin naczyniowych Biebrzańskiego Parku Narodowego i Kotliny Biebrzańskiej = List of vascular plants of the Biebrza National Park and the Biebrza Valley = Gattungsliste Gefäßpflanzen von Biebrza National Park und Biebrza Tal. Red. Cezary Werpachowski. Współpr. Grzegorz Wroceński. Goniądz: Biebrzański Park Narodowy, 2003, ss. 99 [na okł.: 10 lat Biebrzańskiego Parku Narodowego].

Lutomski Jerzy. Ziołolecznictwo. Tradycja i przyszłość. Biblioteka Zdrowego Człowieka, t. 5. Gdańsk: Tower Press, 2003, ss. 144 [zawiera spisy]. 
Łukasiewicz Aleksander. Rośliny okrywowe. Poznań: Państwowe Wydawictwa Rolnicze i Leśne. Oddział, cop. 2003, s. 142 [alfabetyczny spis roślin].

Marosz Adam. Ogród skalny. Warszawa: Wydawnictwo „Działkowiec”, 2003, ss. 107, [1] [Skorowidz nazw polskich; Skorowidz nazw łacińskich].

Piękoś-Mirkowa Halina, Mirek Zbigniew. Atlas roślin chronionych. Seria Flora Polski. Warszawa: Multico Oficyna Wydawnicza, 2003, ss. 584 [zawiera Indeks nazw polskich i łacińskich].

Rośliny lecznicze $w$ weterynarii $i$ zootechnice. Red. nauk. Ała Sadowska. Aut. Ała Sadowska et al. Warszawa: Wydawnictwo SGGW, 2003, ss. 310 [Słownik terminów specjalistycznych, skorowidz].

Sciama Yves. Mały atlas gatunków zagrożonych. Tłum. z jęz. fr. Agnieszka Marcoń. Seria Mała Encyklopedia Larousse. Wrocław: Larousse Polska, cop. 2003, ss. 128, mapy.

Słownik botaniczny. Red. nauk. Alicja i Jerzy Szweykowscy. Aut. not encyklopedycznych: Stanisław Balcerkiewicz et al. Wyd. 2 zm. i uzup. Warszawa: Wiedza Powszechna, 2003, ss. 1136 [zawiera Skorowidz nazw polskich i łacińskich].

Szczepanowicz Barbara. Atlas roślin biblijnych: pochodzenie, miejsce w Biblii i symbolika. Kraków: Wydawnictwo WAM, 2003, ss. 270.

Wielka encyklopedia roślin pokojowych. Ponad 1500 roślin, 250 pomysłów dekoracji. [Pomysły dla każdego wnętrza]. Red. Patrick Mioulane. Z jęz. fr. przeł. Elżbieta Traczewska-Zych. Red. wyd. pol. Donata Łuszczewska. [S.l.]: Oficyna Wydawnicza Delta W-Z, [2003], ss. 511 [Słowniczek terminów fachowych, indeks polskich i łacińskich nazw roślin].

Wojewoda Władysław. Checklist of Polish larger Basidiomycetes = Krytyczna lista wielkoowocnikowych grzybów podstawkowych Polski. Seria Biodiversity of Poland = Różnorodność Biologiczna Polski, vol. 7. Kraków: W. Szafer Institute of Botan. Polish Academy of Sciences, 2003, ss. 812 [indeks].

Wołkowycki Dan. Atlas rozmieszczenia roślin naczyniowych $w$ Bielsku Podlaskim (stan na lata 1996-1997). Phytocoenosis, Supplementum Cartographiae Geobotanicae, 17. Warszawa-Białowieża: Białowieska Stacja Geobotaniczna Uniwersytetu Warszawskiego, 2003, ss. 128 [indeks; napisy pod ilustracjami polskie, angielskie].

Wójciak Hanna. Porosty, mszaki, paprotniki. Seria Flora Polski. Warszawa: Multico, 2003, ss. 368 [Indeks nazw polskich i łacińskich].

Zagrożenie porostów $w$ Polsce $=$ The threat to lichens in Poland. Red. Krystyna Czyżewska. Seria Monographiae Botanicae, vol. 91. Łódź: Polskie Towarzystwo Botaniczne, 2003, ss. 248, [1].

Zielnik dla każdego czyli opis ziół wykorzystywanych w leczeniu domowym wraz z praktycznym zastosowaniem (napary, wywary i wyciagi zdrowotne). Zebrali i oprac. Jan Rogala oraz Robert Maciej. Warszawa: Baobab, 2003, ss. 175, [1] [spis chorób i wykaz ziół leczniczych].

\section{4}

Altmann Horst. Atlas trujących roślin i jadowitych zwierząt. Z niem. przeł. Aldona Zaniewska i Henryk Garbarczyk. Warszawa: Świat Książki, 2004, ss. 159. 
Ardley Neil et al. Encyklopedia juniora. Tłum. Jerzy Podgórski. Konsultacja wyd. pol. Karol Sabath. Il. Neil Bullpit et al. Wyd. 1 w tej ed. Warszawa: Firma Księgarska Jacek i Krzysztof Olesiejuk, 2004, ss. 352 [na okł. podtyt.: woda i powietrze - ciepło, światło i dźwięk - elektryczność i magnetyzm - ruch - rośliny i zwierzęta - odżywianie - rozmnażanie].

Atlas chorób zbóż powodowanych przez grzyby: rozpoznawanie, ocena, zwalczanie. Syngenta Crop Protection, [S.1.]: [s.n.], [post 2004], ss. 58.

Atlas of the Geographical Distribution of Lichens in Poland, Pt. 4 [= Atlas rozmieszczenia geograficznego porostów w Polsce]. Ed. by Urszula Bielczyk, Stanisław Cieśliński, Wiesław Fałtynowicz. Kraków: W. Szafer Institute of the Polish Academy of Sciences, 2004, ss. 110 [tekst równoległy polski, angielski].

Atlas roślin grzybów i porostów chronionych. Tekst i il. Robert Dzwonkowski. Kielce: Mac Edukacja, 2004, ss. 96.

Bielczyk Urszula et al. Checklist of lichens of the Western Carpathians, seria Biodiversity of the Carpathians, vol. 1. Kraków: W. Szafer Institute of Botany. Polish Academy of Sciences, 2004, ss. 181, mapy.

Celka Zbigniew Atlas rozmieszczenia roślin naczyniowych na grodziskach Wielkopolski $=$ Distribution Atlas of Vascular Plants on the Earthworks of Wielkopolska. Prace Zakładu_Taksonomii Roślin UAM w Poznaniu, nr 13. Poznań: Bogucki Wydawnictwo Naukowe, 2004, ss. 447, [1], mapy + Objaśnienia znaków i symboli, k. $1+1$ foliogram [tekst równoległy polski, angielski].

Della Beffa Maria Teresa. Zioła. Seria Podręczny Leksykon Przyrodniczy. Z niem. przeł. Jadwiga Kozłowska. Warszawa: Świat Książki, cop. 2004, ss. 222.

Encyklopedia przyrody. Fauna i flora Europy. Red. prowadzący Bożena Zasieczna. Tłum. Marta Chudzicka et. al. Wyd. 4. Warszawa: Muza, 2004, ss. 384, mapy.

Index plantarum. Red. nauk. Karol Węglarski. Hortus Botanicus Universitatis Posnaniensis. Poznań: Bogucki Wydawnictwo Naukowe, 2004, ss. 383, [1] [indeks łaciński].

Kielak Anna Maria. Zielnik Elizy Orzeszkowej. Nieznany zabytek botaniczny przechowywany w zbiorach Poznańskiego Towarzystwa Przyjaciół Nauk. Poznań: Kontekst, 2004, ss. 151, [1].

Krause Joanna, Lisiecka Anna, Szczepaniak Stanisława. Ozdobne rośliny jednoroczne i dwuletnie. Uprawa w gruncie. Poznań: Wydawnictwo Akademii Rolniczej im. Augusta Cieszkowskiego, 2004, ss. 175 [Skorowidz nazw łacińskich i polskich; słowniczek częściej spotykanych nazw łacińskich].

Lord Tony. Encyklopedia kompozycji ogrodowych. Jak rośliny tworza harmonię kolorów $i$ kształtów. Fot. Andrew Lawson. Tłum. Eleonora Karpuk. Konsultacje Wiesław Gawryś. Łódź: Galaktyka, cop. 2004, ss. 416.

Mułenko Wiesław, Kozłowska Monika, Sałata Bogusław. Microfungi of the Tatra National Park. A checklist = Grzyby mikroskopijne Tatrzańskiego Parku Narodowego. Seria Biodiversity of the Tatra National Park = Bioróżnorodność Tatrzańskiego Parku Narodowego, vol. 1. Kraków: W. Szafer Institute of Botany, Polish Academy of Sciences, 2004, ss. 72.

Olech Maria. Lichens of the Tatra National Park. A checklist = Porosty Tatrzańskiego Parku Narodowego. Adnotowana lista taksonów. Biodiversity of the Tatra Natio- 
nal Park = Bioróżnorodność Tatrzańskiego Parku Narodowego, vol. 2. Kraków: W. Szafer Institute of Botany, Polish Academy of Sciences, 2004, ss. 137 [indeks polski, łaciński].

Podgórscy Barbara i Adam. Polski zielnik kulinarny. Krajowe zioła jadalne i przyprawowe. Leksykon i przepisy. Poznań: Kurpisz, cop. 2004, ss. 274, s. tabl. [20].

Radziul Eugeniusz. Rośliny cenne, rzadkie, poszukiwane. 1. Warszawa: Państwowe Wydawnictwa Rolnicze i Leśne, 2004, ss. 261, [2].

Rausch Andrea, Lotz Brigitte. Zioła: zastosowanie: kulinarne, medyczne, dekoracyjne: leksykon. Tł. Marek Gajewski. [Warszawa]: Elipsa - Poznań: Publicat, 2004, ss. 301, [2].

Rekłajtis-Zawada Agnieszka, Kazubek Tadeusz. Zielnik. Drzewa i krzewy liściaste. Warszawa: Arkady, cop. 2004, ss. 63.

Rośliny doniczkowe. Wybór i oprac. Anna Budziarek. Seria Encyklopedia Ogrodnictwa. Warszawa: Skarbnica Wiedzy, cop., 2004, ss. 144, [16].

Senderski Mateusz Emanuel. Prawie wszystko o ziołach [poradnik]. Il. Aneta Borewicz. Fot. cyfrowa il. Grzegorz Dymarski. Podkowa Leśna: Mateusz E. Senderski, 2004, ss. 668 [Skorowidz nazw polskich i nazw łacińskich roślin zielarskich].

Szczepanowicz Barbara. Atlas roślin biblijnych: pochodzenie, miejsce w Biblii i symbolika. Kraków: Wydawnictwo WAM, 2004, ss. 270.

Urbisz Andrzej. Konspekt flory roślin naczyniowych Wyżyny Krakowsko-Częstochowskiej. Prace Naukowe Uniwersytetu Śląskiego w Katowicach, nr 2240. Katowice: Wydawnictwo Uniwersytetu Śląskiego, 2004, ss. 284, [2].

Urbisz Andrzej, Urbisz Alina. Rośliny zielne i krzewinki Polski - pospolite, częste. Seria Atlas i Klucz. Krzeszowice: Wydawnictwo „Kubajak”, 2004, ss. 264.

Waźbińska Jadwiga, Puczel Urszula. Ćwiczenia z roślin ozdobnych. Cz. 1: Rośliny jednoroczne i dwuletnie. Wyd. 2 uzup. Olsztyn: Wydawnictwo Uniwersytetu Warmińsko-Mazurskiego, 2004, ss. 100, [1] [indeksy].

Wielka ilustrowana encyklopedia roślin ogrodowych. Red. nacz. Jacek Fronczak. Tłum. Małgorzata Kaczarowska et al. Warszawa: Reader's Digest Przegląd, 2004, ss. 864.

Wróbel Henryk. Związki staroczesko-staropolskie w terminologii botanicznej. Wstępem opatrzyła Teresa Zofia Orłoś. Kraków: Scriptum - Instytut Filologii Słowiańskiej Uniwersytetu Jagiellońskiego, 2004, ss. 75, [1] [zawiera glosaria].

Zielski Andrzej, Krąpiec Marek. Dendrochronologia. Warszawa: Wydawnictwo Naukowe PWN, 2004, ss. 328 [Skorowidz rzeczowy i łacińskich nazw roślin i zbiorowisk leśnych].

\section{5}

Augustyn Małgorzata. Rośliny pokojowe. Encyklopedia pielegnacji. Poznań: Wydawnictwo Publicat, cop. 2005, ss. 190, [1].

Encyklopedia roślin pokojowych. Aranżacje. Warszawa: Arti-Centrum, 2005, ss. 335. Index Seminum et Sporarum 2005-2006. Akademia Medyczna w Gdańsku. Wydział Farmaceutyczny. Katedra i Zakład Farmakognozji. Ogród Roślin Leczniczych. Gdańsk: Akademia Medyczna, 2005, ss. 26. 
Krzyściak-Kosińska Renata, Kosiński Marek. Rośliny Polski. Ilustrowana encyklopedia od $A$ do Z. Red. merytoryczna i konsult. Anna Rusińska. Poznań: Publicat Wydawnictwo, cop. 2005, ss. 111, [1] [u dołu okł.: 200 gatunków, 200 fotografii].

Lepert Rajmund, Turyn Ewa. Słownik polsko-łacińsko-francuski. Rośliny i zwierzęta = Dictionnaire polonais-latin-français. Végétaux at animaux. Wiedza Powszechna, Warszawa 2005, ss. 530 [zawiera 39000 nazw; indeks polski, łaciński, francuski].

Lippert Wolfgang, Podlech Dieter. Kwiaty. Tłum. i konsultacja Anna i Stanisław Kłosowscy. Oprac. nauk. Stanisław Kłosowski. Seria Encyklopedia Kieszonkowa. Wyd. 4. Warszawa: Muza SA, 2005, ss. 253, [1] [400 kolorowych fotografii, 250 rysunków].

Marcinkowski Jacek. Katalog bylin polecanych przez Związek Szkótkarzy Polskich. Aut. fot. Piotr Banaszczak et al. Agencja Promocji Zieleni. Związek Szkółkarzy Polskich. Warszawa 2005, ss. 133 [zawiera Słownik nazw rodzajowych polsko-łaciński i łacińsko-polski].

Noordhuis Klaas T. Encyklopedia roślin ogrodowych. Tłum. z jęz. ang. Małgorzata Samborska. Warszawa: Firma Księgarska Jacek i Krzysztof Olesiejuk - Inwestycje, cop. 2005, ss. 319.

Nowak Arkadiusz, Nowak Sylwia. Katalog zielnika roślin naczyniowych Muzeum Ślaska Opolskiego. Zbiory z lat 1855-1940 z terenów spoza dzisiejszej Polski = Catalogue of the vascular plants herbarium of the Opole Silesia Museum. Collection from 1855 to 1940 from the area outside present Poland = Der Katalog des Gefässpflanzenherbariums des Oppelner Schlesien Museums. Die Sammlungen aus den Jahren 1855-1940 von Geländen ausser des heutigen Polens = Katalog herbáře cévnatých rostlin Muzea Opolského Slezska. Sbirky ze let 1855-1940 z území mimo současné Polsko. Tł. Arkadiusz Nowak, Małgorzata Mendela - j. niem., Arkadiusz Nowak - j. ang., Jarosław Radimersky - j. czes. Muzeum Śląska Opolskiego et al. Opole: $\mathrm{Mu}$ zeum Śląska Opolskiego, 2005, ss. 86.

Nowak Arkadiusz, Nowak Sylwia. Katalog zielnika roślin naczyniowych Muzeum Ślaska Opolskiego. Zbiory z lat 1829-1943 z terenów dzisiejszej Polski = Catalogue of the vascular plants herbarium of the Opole Silesia Museum. Collection from 1829 to 1943 from the present area of Poland = Der Katalog des Gefässpflanzenherbariums des Oppelner Schlesien Museums. Die Sammlungen aus den Jahren 1829-1944 von Geländen des heutigen Polens = Katalog herbáre cévnatých rostlin Muzea Opolského Slezska. Sbirky ze let 1829-1943 z území současného Polska. Tłum. Arkadiusz Nowak, Małgorzata Mendela - j. niem., Arkadiusz Nowak - j. ang., Jarosław Radimersky - j. czes. Muzeum Śląska Opolskiego et al. Opole: Muzeum Śląska Opolskiego, 2005, ss. 147.

Nowak Arkadiusz, Nowak Sylwia. Katalog zielnika roślin naczyniowych Muzeum Ślaska Opolskiego. Zbiory z lat 1951-1976 z terenów Polski = Catalogue of the vascular plants herbarium of the Opole Silesia Museum. Collection from 1951 to 1976 from the area of Poland. Opole: Muzeum Śląska Opolskiego, 2005, ss. 209.

Rekłajtis-Zawada Agnieszka. Zielnik. Kwiaty pól i łąk. Il. Magdalena Prugar-Kazubek. Warszawa: Arkady, 2005, ss. 64. 
Rogowska-Cybulska Ewa. Gwarowy obraz roślin w świetle aktywności nominacyjnej ich nazw (na przykładzie gwary wsi Wagi w powiecie łomżyńskim). Gdańsk: Wydawnictwo Uniwersytetu Gdańskiego, 2005 [zawiera Słownik nazw roślin, s. 233-333].

Sarwa Andrzej. Encyklopedia działkowca. Warszawa: Książka i Wiedza, cop. 2005, ss. 428.

Szot-Radziszewska Elżbieta. Sekrety ziół: wiedza ludowa, magia, obrzędy, leczenie. Warszawa: Wydawnictwo Trio, 2005, ss. 279, s. tabl. [48] [zawiera spisy].

Tajemnice polskiej przyrody. Encyklopedia zwierząt i roślin. 1-. Red. Krzysztof Środa. Warszawa: De Agostini Polska, 2005-.

Waźbińska Jadwiga, Puczel Urszula. Ćwiczenia z roślin ozdobnych. Cz. 3: Rośliny doniczkowe. Wyd. 2 popr. i uzup. Olsztyn: Wydawnictwo Uniwersytetu Warmińsko-Mazurskiego, 2005, ss. 134 [indeksy].

Wielka encyklopedia roślin. Główny wydaw. Christopher Brickell. Tłum. Henryk Chmiel, Małgorzata Świdzińska. Wyd. 4. (Nowe wydanie). Warszawa: Muza, 2005, ss. 640 [4250 fotografii].

\section{6}

Augustyn Małgorzata. Rośliny pokojowe. Encyklopedia pielęgnacji. Poznań: Wydawnictwo Publicat, cop. 2006, ss. 190, [1].

Chmiel Maria Alicja. Checklist of Polish larger ascomycetes = Krytyczna lista wielkoowocnikowych grzybów workowych Polski. Seria Biodiversity of Poland = Różnorodność Biologiczna Polski, vol. 8. Kraków: W. Szafer Institute of Botany. Polish Academy of Sciences, 2006, ss 152 [indeks].

Chmiel Julian. Rośliny specjalnej troski $i$ wartościowe obszary przyrodnicze $w$ północnowschodniej Wielkopolsce (= Plants of special care and valuable natural areas in the North-Eastern part of the Wielkopolska). Prace Zakładu Taksonomii Roślin Uniwersytetu im. Adama Mickiewicza w Poznaniu, nr 15. Poznań: Bogucki Wydawnictwo Naukowe, 2006, ss. 97 [zawiera spisy].

Czekalski Mieczysław. Liściaste krzewy ozdobne o wszechstronnym zastosowaniu, 2. Poznań: Państwowe Wydawnictwo Rolnicze i Leśne, cop., 2006, ss. 200 [na okł. podtyt.: Pnacza, krzewy zawsze zielone, rośliny mało znane i w pojemnikach do dekoracji wnętrz; zawiera Indeks nazw łac.].

Encyklopedia polska. Historia, literatura, przyroda, geografia. Aut. tekstu Dariusz Banaszak et al. Red. Eleonora Mierzyńska-Iwanowska et al. Poznań: Publicat Wydawnictwo, cop. 2006, ss. 496 [u dołu okł.: Historia Polski od najdawniejszych śladów osadnictwa po współczesność, najwybitniejsze dzieła i twórcy literatury polskiej - od Bogurodzicy po utwory najnowsze, najciekawsze zwierzęta i rośliny, środowiska naturalne i parki narodowe, krainy geograficzne, geologia, społeczeństwo i gospodarka, ponad 1500 barwnych ilustracji, reprodukcji, fotografii $i$ map].

Fałtynowicz Wiesław, Kukwa Martin. Lista porostów i grzybów naporostowych Pomorza Gdańskiego = List of lichens and lichenicolous fungi of Gdańskie Pomerania. Acta Botanica Cassubica, Monographiae. Gdańsk: Katedra Taksonomii Roślin i Ochrony Przyrody Uniwersytetu Gdańśkiego, 2006, ss. 98 [tekst w językach: polskim, angielskim, łacińskim]. 
Farndon John. Wielka księga faktów [nauka, budowle i transport, geografia, rośliny]. Tł. Danuta Zgliczyńska, Beata Wojtkowska. Warszawa: SBM, cop. 2006, ss. 243, [13].

Flora Cracoviensis Secunda (atlas). Red. Maria Zając, Adam Zając, Bogdan Zemanek. Aut. Wacław Bartoszek et al. Przeł. Roman Tertil, Ian Harman. Kraków: nakł. Pracowni Chorologii Komputerowej Instytutu Botaniki Uniwersytetu Jagiellońskiego, 2006, ss. 290, [1], k. luzem [2] [Tekst równoległy polski, angielski].

Garbarczyk Henryk. Zielnik. Zioła łąk i ogrodów. Il. Magdalena Prugar-Kazubek. Warszawa: Arkady, 2006, ss. 63, [1].

Haberer Martin. Rośliny pokojowe. Atlas kieszonkowy. 350 roślin do pokoju i ogrodu zimowego. Z niem. przeł. Krystyna Mazur. Warszawa: Oficyna Wydawnicza Delta W-Z, [ca 2006], ss. 192 [zawiera skorowidz polskich i łacińskich nazw roślin].

Haberer Martin. Rośliny rabatowe i balkonowe: atlas kieszonkowy: 222 rośliny ozdobne na rabaty $i$ balkony. Z niem przeł. Krystyna Mazur. Warszawa: Delta, [ca 2006], ss. 127, [1].

Iburg Anne. Domowe leki ziołowe: leksykon: substancje czynne, działanie, stosowanie. Fot. Roland Spohn. Tłum. Krystyna Niecikowska-Jastrzębska. Warszawa: Elipsa, cop. 2006, ss. 284.

Impelluso Lucia. Natura $i$ jej symbole. Rośliny i zwierzęta. Seria Leksykon: historia, sztuka, ikonografia. Tłum. Hanna Cieśla. Warszawa: Arkady, 2006, s. 382, [1].

Iwaniuk Arkadiusz. Atlas ziół krajowych. Warszawa: Dom Wydawniczy Bellona, cop. 2006, ss. 142, [1].

Kolorowy atlas świata: mapy, zwierzęta, rośliny, środowiska, ciekawostki. Konsultacja merytoryczna i konsultacja kartograficzna Michał Siwicki. Il. Liku. Warszawa: Wydawnictwo Wilga, 2006, s. [12] + karty do gry [na okł.: Książka przeznaczona dla dzieci powyżej 3 lat].

Kołtowski Zbigniew. Wielki atlas roślin miododajnych. Fot. Zbigniew Kołtowski. Il. Iwona Miśkiewicz. Seria Biblioteka Przeglądu Pszczelarskiego. Warszawa: Przedsiębiorstwo Wydawnicze Rzeczpospolita, 2006, ss. 327 [na okł.: Zielne rośliny pożytkowe; Drzewa i krzewy pożytkowe].

Kossowska Maria. Checklist of lichens and allied fungi of the Polish Karkonosze Mts. Kraków: W. Szafer Institute of Botany. Polish Academy of Sciences, 2006, ss. 131 [indeksy; wykaz porostów w języku łacińskim].

Kwiatkowski Paweł. Current state, separateness and dynamics of vascular flora of the Góry Kaczawskie (Kaczawa Mountains) and Pogórze Kaczawskie (Kaczawa Plateau). 1: Distribution atlas of vascular plants. Kraków: W. Szafer Institute of Botany. Polish Academy of Sciences, 2006, ss. 467 + foliogram [tyt. grzb.: Atlas of vascular plants of the Góry Kaczawskie MTS].

Leksykon zdrowia. Rośliny lecznicze, minerały, suplementy i witaminy. Aut. Marcin Pustkowski et al. Bielsko-Biała: Wydawnictwo Park, cop. 2006, ss. 576.

Mikołajczyk Krystyna, Wierzbicki Adam. Zioła źródłem zdrowia [leksykon]. Warszawa: Oficyna Wydawniczo-Poligraficzna „Adam”, 2006, ss. 448, XVI.

Rausch Andrea, Lotz Brigitte. Zioła. Zastosowanie: kulinarne, medyczne, dekoracyjne. Leksykon. Tłum. Marek Gajewski. Warszawa: Elipsa, 2006, ss. 301. 
Red list of plants and fungi in Poland = Czerwona lista roślin i grzybów Polski. Ed. by Zbigniew Mirek et al. Kraków: W. Szafer Institute of Botany. Polish Academy of Sciences, 2006, ss. 99.

Rośliny i zwierzęta. Oprac. wersji pol. Wydawnictwo Atlas, seria Co i Jak, nr 8. Warszawa: Edipresse Polska, [ca 2006], ss. 33 + płyta VCD [na okł.: ciekawostki, krzyżówki, zagadki, 2 filmy; podtyt. okł.: zwierzęta w Europie, drzewa, dzikie kwiaty, badanie natury; na płycie dwa filmy popularnonaukowe: Drzewa i Kolej].

Rośliny pokojowe i balkonowe. Nastrojowe wnętrze. Przekł. Elżbieta Tarnas. Red. Tomasz Ostromęcki. Red. nauk. Elżbieta Potocka. Kolonia: Naumann \& Göbel Verlagsgesellschaft - Warszawa: Firma Księgarska Jacek i Krzysztof Olesiejuk, [ca 2006], ss. 160 [na okł.: $W$ książce leksykon roślin od A do Z].

Stebel Adam. Atlas rozmieszczenia wątrobowców chronionych Polski w województwie śląskim (= Distribution atlas of Polish legally protected liverworts in Silesia Province). Red. t. Jerzy B. Parusel. Seria Materiały, Opracowania, Centrum Dziedzictwa Przyrody Górnego Śląska, t. 9. Katowice: Centrum Dziedzictwa Przyrody Górnego Śląska, 2006, ss. 37.

Szweykowski Jerzy. An annotated checklist of Polish liverworts and hornworts = Krytyczna lista wątrobowców i glewików Polski. Seria Biodiversity of Poland = Różnorodność biologiczna Polski, vol. 4. Kraków: W. Szafer Institute of Botany, Polish Academy of Science, 2006, ss. 114.

Vermeulen Nico. Encyklopedia roślin domowych. Tłum. Jakub Kutner. Red. nauk. i jęz. Elżbieta Potocka. Warszawa: Firma Księgarska Jacek i Krzysztof Olesiejuk - Inwestycje, cop. 2006, ss. 320.

Waźbińska Jadwiga. Ćwiczenia z roślin ozdobnych. Cz. 2: Byliny. Wyd. 2 uzup. Olsztyn: Wydawnictwo Uniwersytetu Warmińsko-Mazurskiego, 2006, ss. 199, [1] [indeksy nazw łacińskich].

Wielka encyklopedia roślin. Red. Janet Marinelli. Z ang. przeł. Dorota Dobrowolska et al. Warszawa: Świat Książki, 2006, ss. 503.

Więcław Helena. Flora roślin naczyniowych Ińskiego Parku Krajobrazowego i jej antropogeniczne przeobrażenia. Cz. 2: Atlas rozmieszczenia roślin, Uniwersytet Szczeciński. Seria Rozprawy i Studia, Uniwersytet Szczeciński, t. 665 (591). Szczecin: Wydawnictwo Naukowe Uniwersytetu Szczecińskiego, 2006, ss. 226.

Witosławski Piotr. Atlas of distribution of vascular plants in Łódź = Atlas rozmieszczenia roślin naczyniowych $w$ Łodzi. Łódź: Wydawnictwo Uniwersytetu Łódzkiego, 2006, ss. 386.

Wolff Jürgen, Throll Angelika. Encyklopedia roślin ogrodowych. Portrety ponad 2500 roślin. Z niem. przeł. Barbara Floriańczyk. Red. Iwona Kowalewska. Warszawa: Delta, [2006], ss. 304.

\section{7}

Aranżacje. Encyklopedia roślin pokojowych [A-Z]. Warszawa: Przedsiębiorstwo Wydawniczo-Handlowo-Usługowe ARTI CENTRUM, cop. 2007, ss. 335.

[A-Z]. Ilustrowana encyklopedia Polski. Sławni Polacy, zabytki, zwierzęta, rośliny. Red. Eleonora Mierzyńska-Iwanowska, Małgorzata Potocka, Justyna Sell. Poznań: Wydawnictwo Publicat, cop. 2007, ss. 448. 
Bürki Moritz, Fuchs Marianne. Leksykon roślin doniczkowych i balkonowych. Z niem. przeł. Dorota Walentyn-Góral. Warszawa: Świat Książki. Bertelsmann Media, 2007, ss. 360.

Cebrat Jan. Atlas anatomii roślin. Wrocław: Wydawnictwo Uniwersytetu Przyrodniczego, 2007, ss. [539].

Ciereszko Barbara, Rak Jarosław. Encyklopedia roślin pokojowych. Warszawa: Multico Oficyna Wydawnicza, 2007, ss. 288.

Cygan Stanisław. Słownictwo pism Stefana Żeromskiego. T. 9: Świat roślin. Kraków: Universitas, 2007, ss. 604, [4].

Drobnik Jacek. Zielnik i zielnikoznawstwo. Warszawa: Wydawnictwo Naukowe PWN, 2007, ss. X, 284 [zawiera angielsko-polski słownik pojęć związanych z zielnikiem].

Encyklopedia zdrowia - zioła. Wybór i oprac. zespół red. Zdjęcia Tomasz Wójcik, Magdalena Szwedkowicz-Kostrzewa. Warszawa: Skarbnica Wiedzy, 2007, ss. 176.

Fletcher Neil. Kieszonkowy atlas kwiatów dziko rosnących. Tłum. z jęz. ang. Paulina Łukomska. Seria Kieszonkowy Atlas. Warszawa: Solis, cop. 2007, ss. 296 [indeks].

Garbarczyk Henryk. Zielnik. Runo leśne. Il. Magdalena Prugar-Kazubek. Warszawa: Arkady, 2007, ss. 64.

Haberer Martin. Wielki atlas roślin ogrodowych i pokojowych. 1200 roślin do ogrodu, na taras, balkon, do mieszkania. 1220 barwnych zdjęć. Z niem. przeł. Krystyna Mazur. Warszawa: Delta, [2007], ss. 697 [zawiera skorowidz polskich i łacińskich nazw roślin].

Iburg Anne. Domowe leki ziołowe. Stosowanie, działanie, substancje czynne. Fot. Roland Spohn. Warszawa: Elipsa - Poznań: Publicat, 2007, ss. 284.

Iwaniuk Arkadiusz. Atlas ziół krajowych. Warszawa: Dom Wydawniczy Bellona, cop. 2007, ss. 142, [2].

Juszko Sebastian. Flora i fauna Łazienek. Przewodnik po wybranych gatunkach. Warszawa: Muzeum Łowiectwa i Jeździectwa, 2007, ss. 256.

Krzyściak-Kosińska Renata, Kosiński Marek. Atlas roślin. Seria Przydatny z Natury Rzeczy. Bielsko-Biała: Pascal, cop. 2007, ss. 271.

Mały atlas kwiatów ogrodowych: kiedy sadzić, jak i gdzie. Tekst Hanna Czerska. Warszawa: Przedsiębiorstwo Wydawnicze Rzeczpospolita, [ca 2007], ss. 67.

Moja pierwsza encyklopedia - natura. Tekst Thea Feldman et al. Tłum. Zuzanna Kondej, Małgorzata Szyszko-Kondej. Seria Disney Uczy. Warszawa: Wydawnictwo Egmont Polska, 2007, ss. 191, [1].

Pastusiak Kazimiera. Pogranicze polsko-białorusko-ukraińskie w świetle danych językowych i etnograficznych na podstawie nazw roślin. Seria Język na Pograniczach, 32. Instystut Slawistyki PAN, Fundacja Slawistyczna. Warszawa: Slawistyczny Ośrodek Wydawniczy, 2007, ss. 423 [zawiera: indeks; Nazwy botaniczne łacińskie, s. 369372; Nazwy gwarowe polskie, s. 373-379; Nazwy gwarowe białoruskie, s. 380-395; Nazwy gwarowe ukrainskie, s. 395-416].

Politycka Barbara. Słownik terminów z fizjologii roślin angielsko-polski i polsko-angielski = English-Polish and Polish-English dictionary of plant physiology terms. Poznań: Wydawnictwo Akademii Rlniczej im. Augusta Cieszkowskiego,2007, ss. 87. 
Praktyczny stownik farmaceutyczny angielsko-polski i polsko-angielski $=$ Practical pharmaceutical dictionary English-Polish and Polish-English. Red. nacz. Jarosław Jóźwiak. Warszawa: Medyk, 2007, ss. 645, ss. tabl. [8].

Rośliny. Wspólnie odkrywamy świat. Tłum. Ewa Majkowska-Reutt. Seria Zadziwiający Świat Faktów: encyklopedia dla dzieci = Amazing children's encyklopedia the world of facts. Warszawa: Przedsiębiorstwo Wydawniczo-Handlowe „Arti” Artur Rogala, Mariusz Rogala, cop. 2007, ss. 32, [1].

Rośliny w akwarium. Red. Darek Firlej. Seria Wielka Encyklopedia Akwarystyki, cz. 2 t. 1. Warszawa: Magazyn Akwarium D. Firlej, 2007, ss. 178.

Senderski Mateusz Emanuel. Prawie wszystko o ziołach. [Poradnik]. Il. Aneta Borewicz. Fot. cyfrowa il. Grzegorz Dymarski. Wyd. 2 popr. i uzup. Podkowa Leśna: Mateusz E. Senderski, 2007, ss. 670, [1] [zawiera Skorowidz nazw polskich i nazw łacińskich roslin zielarskich].

Rośliny. Tekst Inga Szwedler. Zdj. Zbigniew Nawara. Red. nauk. Barbara Sudnik-Wójcikowska. Seria Kocham Polską Przyrodę - Spotkania z Przyrodą. Warszawa: Multico Oficyna Wydawnicza, cop. 2007, ss. 397 [indeks].

Throll Angelika. Atlas roślin ogrodowych. [1000 roślin. Opis, pielegnowanie, zastosowanie, odmiany]. Z jęz. niem. przeł. Krystyna Mazur, Barbara Floriańczyk. Red. Zofia Bujnowska. Warszawa: Delta, 2007, ss. 448.

Walker Richard. Rośliny. Il. Jim Channell et al. Seria Disney Encyklopedia Wiedzy, 15. Warszawa: Paperview - Axel Springer Polska, 2007, ss. 57.

\section{8}

A preliminary checklist of micromycetes in Poland = Wstępna lista grzybów mikroskopijnych Polski. Ed. by Wiesław Mułenko, Tomasz Majewski, Małgorzata Ruszkiewicz-Michalska. Seria Biodiversity of Poland = Różnorodność Biologiczna Polski, vol. 9. Kraków: W. Szafer Institute of Botany Academy of Science, 2008, ss. 752 [indeks]. Atlas roślinności rzeczywistej Krakowa. Red. nauk. Eugeniusz Dubiel, Jerzy Szwagrzyk. Aut. tekstów Eugeniusz Dubiel et al. Kraków: Urząd Miasta Krakowa. Wydział Kształtowania Środowiska, cop. 2008, 1 atlas (ss. 159), mapy, oprawa kołonottanikowa [na okł.: Kraków forma i treść, ochrona środowiska].

Atlas ziót. Wybór i oprac. Emilia Grzędzicka. Zdj. Tomasz Wójcik, Magdalena Szwedkowicz-Kostrzewa. Warszawa: Buchmann, cop. 2008, ss. 240 [na okł.: Przeglad popularnych roślin leczniczych, dodatkowo wiadomości dotyczące przyrządzania leków ziołowych].

Augustyn Małgorzata. Piękne rośliny w każdym domu. Poznań: Wydawnictwo Publicat, 2008, ss. 591, [1] [Na okł.: leksykon roślin pokojowych, najpopularniejsze gatunki, praktyczne wskazówki pielegnacyjne].

Bellmann Heiko et al. Rodzinny atlas przyrody. Tłum. Paulina Berndt, Warszawa: Wydawnictwo RM, 2008, ss. 191. [1].

Bohne Burkhard, Dietze Peter. Rośliny trujące: 170 gatunków roślin ozdobnych i dziko rosnacych. Przeł. Arkadiusz Iwaniuk, Warszawa: Bellona, 2008, ss. 128.

Dreyer Eva Maria. Zioła oraz ich trujące sobowtóry: poradnik dla zbieraczy. Z jęz. niem. przeł. Jerzy Woźniak. Warszawa: Klub dla Ciebie, 2008, ss. 141, [3] [zawiera spis placówek toksykologicznych]. 
Garbarczykowie Małgorzata i Henryk. Zielnik. Drzewa i krzewy owocowe. Il. Tadeusz Kazubek. Warszawa: Arkady, 2008, ss. 64.

Gawryś Wiesław. Słownik roślin zielnych. Łacińsko-polski. Officina Botanica, Kraków 2008, ss. 199.

Grzebisz Witold. Nawożenie roślin uprawnych. T. 1: Podstawy nawożenia. Poznań: Państwowe Wydawnictwo Rolnicze i Leśne, 2008, ss. 428, s. tabl. [24] [Dla studentów uczelni rolniczych; zawiera Wykaz nazw gatunkowych wybranych roślin uprawnych].

Grzelakowa Eliza. W poszukiwaniu Edenu. Językowo-kulturowy obraz współczesnegp polskiego ogrodu ozdobnego. Kreacja czasu i przestrzeni. Gniezno: Oficyna Tum, 2008, ss. 311, ss. tabl. [40] [zawiera słownik (ok. 700 haseł); cz. 1: Świat roślin; cz. 2: Człowiek w ogrodzie; cz. 3: Nazwy założeń ogrodowych].

Kosiński Marek, Krzyściak-Kosińska Renata. Atlas ziół, seria Przydatny z Natury Rzeczy. Bielsko-Biała: Pascal, 2008, ss. 272.

Leksykon roślin i zwierząt Polski. Praktyczny przewodnik. Aut. Renata Krzyściak-Kosińska et al. Poznań: Elipsa, 2008, ss. 416.

Łuszczyński Janusz. Basidiomycetes of the Góry Świętokrzyskie Mts. A checklist. Kielce: Wydawnictwo Uniwersytetu Humanistyczno-Przyrodniczego Jana Kochanowskiego, 2008, ss. 240, [2].

Nowak Arkadiusz et al. Aтлас сосудистых растений Таджикистана. Ч. 1 = Atlas roślin naczyniowych Tadżykistanu. Cz. 1. Tłum. na jęz. ros. Elena Jagt-Yazykova. Opole: Stowarzyszenie Ochrony Przyrody BIOS - Studio Impreso Przemysław Biliczak, 2008, ss. 232.

Ostrowski Janusz et al. Atlas niedoborów wodnych roślin uprawnych i użytków zielonych $w$ Polsce $=$ Atlas of water deficits of cultivated plants and grasslands in Poland. Red. nauk. Janusz Ostrowski, Leszek Łabędzki. Instytut Melioracji i Użytków Zielonych w Falentach, Instytut Geodezji i Kartografii w Warszawie. Falenty-Warszawa: Wydawnictwo IMUZ, 2008, 1 atlas (k. 19,32), mapy.

Rapiejko Piotr. Alergeny pyłku roślin, Warszawa: Medical Education, 2008, ss. 91, [1] [do części nakładu dołączona płyta CD pt. Atlas fotografii roślin alergogennych].

Szcześniak Krystyna. Świat roślin światem ludzi na pograniczu wschodniej i zachodniej Słowiańszczyzny. Gdańsk: Wydawnictwo Uniwersytetu Gdańskiego, 2008, ss. 410, +1 dysk opt. CD-ROM [zawiera Słownik [magicznych zastosowań roślin, których nazwy zostały zapisane w słowniczku Zośki Wieras $i w$ fitonimicznych materiałach Elizy Orzeszkowej], s. 120-335 (z ekwiwalentami białoruskimi, rosyjskimi i łacińskimi); Indeks nazw roślin: Nazwy łacińskie (355-363); Nazwy pisane cyrylica (s. 363-380); Nazwy zapisane łacinka (s. 380-410)].

Waźbińska Jadwiga, Puczel Urszula, Płoszaj Beata. Ćwiczenia z roślin ozdobnych. Cz. 1: Rośliny jednoroczne i dwuletnie. Wyd. 3 uzup. Olsztyn: Wydawnictwo Uniwersytetu Warmińsko-Mazurskiego, 2008, ss. 107, [1] [indeksy].

Waźbińska Jadwiga, Kawecki Zdzisław, Płoszaj Beata. Drzewa i krzewy iglaste. Wyd. 2 uzup. Olsztyn: Wydawnictwo Uniwersytetu Warmińsko-Mazurskiego, 2008, ss. 182, [1] [indeks].

Witkowska-Żuk Leokadia. Atlas roślinności lasów. Seria Flora Polski. Warszawa: Multico Oficyna Wydawnicza, cop. 2008, ss. 592. 


\section{9}

Amann Gottfried. Drzewa i krzewy: kieszonkowy atlas liści, kwiatów, owoców, nasion, pędów bezlistnych i siewek najważniejszych gatunków drzew i krzewów lasów Europy Środkowej, zawierający część opisująca ich budowę i rozwój. Tłum. z jęz. niem. Jarosław Malec. Seria Flora i Fauna Lasów. Warszawa: Multico Oficyna Wydawnicza, cop. 2009, ss. 220.

Amann Gottfried. Rośliny runa: kieszonkowy atlas najciekawszych grzybów, porostów, mchów, paprotników, traw, ziół rosnacych w lasach środkowej Europy wraz z opisem ich budowy i życia. Tł. z jęz. niem. Stefan Łukomski. Seria Flora i Fauna Lasów. Warszawa: Multico Oficyna Wydawnicza, cop. 2009, ss. 416.

Atlas siedlisk dna polskich obszarów morskich. Waloryzacja przyrodnicza siedlisk morskich (=Atlas of Polish marine area bottom habitats: environmental valorization of marine habitats). Red. Gabriela Gic-Grusza et al. Oprac. kartogr. Lucyna Kryla-Straszewska, Jacek Urbański. Tłum. na jęz. ang. Jennifer Carter-Zielińska. Gdynia: Broker-Innowacji Gabriela Gic-Grusza, 2009, 1 atlas (ss. 179, [1]), mapy.

Atlas siedlisk dna polskich obszarów morskich. Waloryzacja przyrodnicza siedlisk morskich (=Atlas of Polish marine area bottom habitats: environmental valorization of marine habitats), [dokument elektroniczny]. Red. Gabriela Gic-Grusza et al. Oprac. kartogr. Lucyna Kryla-Straszewska, Jacek Urbański. Tłum. na jęz. ang. Jennifer Carter-Zielińska. Gdynia: Broker-Innowacji Gabriela Gic-Grusza, 2009, 1 dysk optyczny (CD-ROM).

Brud Władysław S., Konopacka-Brud Iwona. Podstawy perfumerii. Historia, pochodzenie i zastosowania substancji zapachowych. Łódź: Oficyna Wydawnicza MA, 2009, ss. 291 [zawiera spis roślin aromatycznych].

Cunningham Scott. Encyklopedia magicznych roślin. Tłum. Paweł Karpowicz. Białystok: Studio Astropsychologii, 2009, ss. 315, [1] [na okł.: Encyklopedia Cunningha$m a]$.

Garbarczykowie Małgorzata i Henryk. Zielnik. Rośliny uprawne. Il. Magdalena Prugar-Kazubek. Warszawa: Arkady, 2009, ss. 64.

Krzyściak-Kosińska Renata, Kosiński Marek. Atlas roślin. Bielsko-Biała: Wydawnictwo Dragon, 2009, ss. 95.

Marcinkowki Jacek. Kosaćce. Seria Królowe Ogrodów. Warszawa: Wydawnictwo Działkowiec, 2009, ss. 87 [indeks nazw polskich i łacińskich].

Moja mała encyklopedia - rośliny. Tłum. Zuzanna Kondej, Małgorzata Szyszko-Kondej. Seria Disney Kubuś Puchatek. Disney Uczy. Warszawa: Wydawnictwo Egmont Polska, 2009, ss. 41.

Paradowski Adam. Atlas chwastów. Aut. zdjęć Marzena Błażewicz-Woźniak et al.. Aut. rys. Olga Migdał. Kraków: Plantpress, cop., 2009, ss. 229 [zawiera słowniczek; Indeks nazw łacińskich].

Przyprawy. Nazewnictwo botaniczne PN-EN ISO 676:2009 = Spices and Condiments. Botanical Nomenclature (ISO 676:1995, including Cor 1:1997) = Épices. Nomenclature botanique (ISO 676:1995, Cor 1:1997 inclus). Polski Komitet Normalizacyjny. Warszawa 2009, ss. 21 [Norma Europejska EN ISO 676:2009 ma status Polskiej Nor$m y$; tekst w języku angielskim, francuskim]. 
Romer Marion. Aromaterapia. Leksykon roślin leczniczych. Red. wyd. pol. Władysław S. Brud. Tłum. Katarzyna Hanusz. Wrocław: MedPharm Polska, 2009, ss. XI, 180. Rośliny pokojowe. Praktyczna encyklopedia. Praca zbiorowa pod kierownictwem Patricka Mioulane. Red. Alain Delavie et al. Tłum. i konsultacja merytoryczna Jerzy Woźniak. Larousse. Warszawa: Hachette Livre Polska, 2009, ss. 510.

Sokolowski Ilka, Toll Claudia. Mój pierwszy zielnik. Zbieramy i utrwalamy rośliny. Z barwnymi il. Rity Lüder. Z niem. przeł. Leszek Karnas. Warszawa: Klub dla Ciebie, cop. 2009, ss. 88 .

Storl Wolf-Dieter. Zioła lecznicze i magiczne: dziewięć magicznych ziót. Tł. Mirosław Łanczkowski. Białystok: Studio Astropsychologii, 2009, ss. 223, s. tabl. [8] [Spis przepisów wg nazw roślin i zastosowania; indeksy].

Waźbińska Jadwiga, Puczel Urszula, Płoszja Beata. Ćwiczenia z roślin ozdobnych. Cz.

2: Byliny. Wyd. 3 uzup. Olsztyn: Wydawnictwo Uniwersytetu Warmińsko-Mazurskiego, 2009, ss. 193 [indeksy].

Waźbińska Jadwiga, Puczel Urszula. Ćwiczenia z roślin ozdobnych. Cz. 3: Rośliny doniczkowe. Wyd. 2 popr. i uzup. Olsztyn: Wydawnictwo Uniwersytetu Warmińsko-Mazurskiego, 2009, ss. 135 [indeksy].

Zielnik dla każdego czyli Opis ziót wykorzystywanych w leczeniu domowym wraz z praktycznym zastosowaniem (napary, wywary $i$ wyciagi zdrowotne). Zebr. i oprac. Jan Rogala oraz Robert Maciej. Wybór i wstęp Jan Rogala. Warszawa: Wydawnictwo Olesiejuk, cop. 2009, ss. 175, [1].

\section{0}

Aleje Doliny Baryczy: inwentaryzacja zadrzewień liniowych $w$ krajobrazie otwartym Doliny Baryczy. Koordynacja, oprac. koncepcji, metodyki i danych oraz red. wyd. Piotr Tyszko-Chmielowiec. Zbieranie danych i opisy gmin Waldemar Blaźniak et al. Wrocław: Fundacja Eko-Rozwoju, 2010, ss. 72.

Atlas ziół: naturalnie kieszonkowy: medycyna naturalna, kuchnia, kosmetyka. Aut. tekstów: Michał Mazik, Marcin Pastwa. Seria Natura. Bielsko-Biała: Wydawnictwo Dragon, 2010, ss. 143, [1].

Bürki Moritz, Fuchs Marianne. Leksykon roślin doniczkowych i balkonowych. Z niem. przeł. Dorota Walentyn-Góral. Warszawa: Świat Książki, 2010, ss. 360.

Frohne Dietrich przy współpr. Birgit Classen. Leksykon roślin leczniczych. Przewodnik naukowy. Tł. Wiktoria Palczewska, Iwona Zawada. Red. Alicja Noculak-Palczewska. Wyd. 1 pol. Wrocław: MedPharm Polska, cop. 2010, ss. 585.

Iwaniuk Arkadiusz. Atlas ziół krajowych. Warszawa: Bellona, cop. 2010, ss. 142, [1].

Kosiński Marek, Krzyściak-Kosińska Renata. Atlas roślin. Bielsko-Biała: Wydawnictwo Pascal, 2010, ss. 269 [na okł.: przydatny z natury rzeczy].

Krzyściak-Kosińska Renata, Kosiński Marek. Atlas roślin: naturalnie kieszonkowy. Zdjęcia Marzena, Michał i Jacek Bronowscy. Seria Natura, Bielsko-Biała: Wydawnictwo Dragon, 2010, ss. 143, [1].

Pastok Dorota, Pyka Walter. Alfabetyczny zielnik w malarstwie i poezji. Kołobrzeg: Wydawnictwo Kamera, 2010, ss. 51, [5]. 
Przyroda Bielan warszawskich. Red. nauk. Maciej Luniak. Wyd. 2. Warszawa: Muzeum i Instytut Zoologii PAN, 2010, ss. 312 [Słowniczek nazw gatunków roślin i zwierząt w języku polskim i łacińskim; indeks].

Rak Jarosław. Kwiaty w Twoim domu. [Leksykon roślin doniczkowych od A do Z]. Warszawa: MULTICO Oficyna Wydawnicza, 2010, ss. 261 [Na okł.: 124 gatunki, modne, dekoracyjne, latwe w uprawie, odporne].

Rapiejko Piotr. Alergeny pyłku roślin. Wyd. 1. (dodruk 2010). Warszawa: Medical Education, 2010, ss. $90+\mathrm{CD}$ [CD pt. Atlas fotografii roślin alergogennych].

Szweykowski Jerzy, Klama Henryk. Liverworts of the Tatra National Park. A checklist $=$ Watrobowce Tatrzańskiego Parku Narodowego. Seria Biodiversity of the Tatra National Park = Bioróżnorodność Tatrzańskiego Parku Narodowego, vol. 3. Kraków: W. Szafer Institute of Botany, Polish Academy of Sciences, 2010, ss. 60 [indeks].

Urbisz Andrzej, Urbisz Alina. Rośliny zielne i krzewinki Polski - pospolite, częste. Seria Atlas i Klucz. Krzeszowice: Wydawnictwo „Kubajak”, 2010, ss. 264.

Wielki leksykon roślin. [Dokument elektroniczny]. Warszawa: Komputer Świat, 2010, 1 dysk optyczny (DVD-ROM) [Program zawiera szczegółowy opis 2500 roślin ogrodowych i domowych, wskazówki na temat ich pielęgnacji, a także informacje o chorobach, leczeniu oraz szkodnikach. Opisy są wzbogacone o zdjęcia, do dyspozycji mamy system filtrów umożliwiający wyszukiwanie roślin według różnych kryteriów. Istnieje możliwość wprowadzania własnych notatek przypisanych konkretnym roślinom].

\section{1}

Atlas ziół. Wybór i oprac. Emilia Grzędzicka. Zdj. Tomasz Wójcik, Magdalena Szwedkowicz-Kostrzewa. Warszawa: Buchmann, cop. 2011, ss. 240 [na okł.: Przeglad popularnych roślin leczniczych. Dodatkowo wiadomości dotyczące przyrządzania leków ziołowych].

Bauer Ute, Grothe Bärbel. Róże. Najpiękniejsze gatunki róż na każdą rabatę. Tł. Katarzyna Iwańska. Seria Quickfinder. Warszawa: Hachette Polska, 2011, ss. 202, [1] [na okł.: wykaz odpowiednich odmian róż do twojego ogrodu, charakterystyka ponad 100 typowych gatunków, ciekawe aranżacje różanych rabat i pergoli; indeks].

Jakubowska-Gabara Janina et al. Atlas rozmieszczenia roślin naczyniowych $w$ Polsce Srodkowej: gatunki chronione, rzadkie, ginące i narażone. Łódź: Wydawnictwo Uniwersytetu Łódzkiego, 2011, ss. 283.

Lingg Adelheid. Zioła przez cały rok. Z niem. przeł. Barbara Janowska-Michnowska. Warszawa: Weltbild Media - Klub dla Ciebie, cop. 2011, ss. 187, [4].

Nobis Marcin et al. Atlas of vascular plants of Tajikistan. Pt. 2. Kraków-Opole: Opole Scientific Society etc., 2011, ss. 256.

Nowak Arkadiusz et al. Atlas of vascular plants of Tajikistan. Pt. 3, Opole-Kraków: Institute of Botany Jagiellonian University etc., 2011, ss. 232.

Przybyłowiczowie Anna i Łukasz. Rośliny: lasy - drzewa. Red. prowadzący Paweł Zalewski. Seria Encyklopedia Przyrody: skarby polskiej natury, t. 2. Warszawa: De Agostini Polska, cop. 2011, ss. 48. 
Przybyłowiczowie Anna i Łukasz. Rośliny: rzadkie i chronione. Red. prowadzący Jakub Czajkowski, Paweł Zalewski. Seria Encyklopedia Przyrody: skarby polskiej natury, t. 7. Warszawa: De Agostini Polska, cop. 2011, ss. 48.

Przybyłowiczowie Anna i Łukasz. Rośliny: rośliny górskie. Red. prowadzący Jakub Czajkowski, Paweł Zalewski. Seria Encyklopedia Przyrody: skarby polskiej natury, t. 10. Warszawa: De Agostini Polska, cop. 2011, ss. 48.

Rośliny. Tłum. Ewa Majkowska-Reutt. Red. Paulina Kędziora. Seria Ilustrowana Encyklopedia - Arti. Warszawa: Przedsiębiorstwo Wydawniczo-Handlowe „Arti” Artur Rogala, Mariusz Rogala, cop. 2011, ss. 32.

Schuster Thomas. Choroby roślin. Środki ochrony roślin i sposoby walki ze szkodnikami. Tł. Anna Wolsan. Seria Quickfinder. Warszawa: Hachette Polska, 2011, ss. 178, [1] [na okł.: szybka identyfikacja chorób na podstawie zamieszczonych fotografii, wykaz skutecznych środków ochrony roślin ogrodowych i pokojowych, ponad 120 opisów zdjęć szkodników i chorób roślin; zawiera Słowniczek].

Włodarczyk Zofia. Rośliny biblijne. Leksykon. Kraków: Instytut Botaniki im. W. Szafera Polskiej Akademii Nauk, cop. 2011, ss. 244, [2].

Zielnik dla każdego czyli opis ziót wykorzystywanych w leczeniu domowym wraz z praktycznym zastosowaniem (napary, wywary i wyciagi zdrowotne). Zebrali i oprac. Jan Rogala oraz Robert Maciej. Seria Z Babcinego Notatnika. Ożarów Mazowiecki: Firma Księgarska Olesiejuk, 2011, ss. 175, [1] [Spis chorób i wykaz ziół leczniczych].

\section{2}

Czachorowska Magdalena. Świat roślin w pismach Bolesława Prusa. Bydgoszcz: Wydawnictwo Uniwersytetu Kazimierza Wielkiego, 2012, ss. 181 [zawiera Słownik roślin].

Encyklopedia ziół. Aut.: Łukasz Fiedoruk, Michał Mazik, Marcin Pastwa. Bielsko-Biała: Wydawnictwo Dragon, 2012, ss. 191, [1].

Frey Ludwik, Tybur Janusz. Atlas roślin pienińskich: kwiaty św. Kingi. Kraków: Instytut Botaniki im. W. Szafera, Polska Akademia Nauk, 2012, ss. 249, [1].

Hołubowicz-Kliza Grażyna, Korbas Marek. Rolniczy atlas chorób. Puławy: Instytut Nawożenia i Gleboznawstwa - Państwowy Instytut Badawczy, cop. 2012, ss. 327, [1].

Houdret Jessica. Wielka księga ziół leczniczych: tradycyjne środki ziołowe, które pomagaja zwalczać częste dolegliwości, przyrządzanie krok po kroku, pokazane na ponad 750 fotografiach, ułożone alfabetycznie opisy 235 ziót, ze szczególnym uwzględnieniem leczniczych zastosowań każdego z nich. Tłum. Jan Halbersztat. Warszawa: Reader's Digest Przegląd, 2012, ss. 256.

Kamiński Wiesław et al. Atlas przyrody: naturalnie kieszonkowy. Seria Natura, Bielsko-Biała: Wydawnictwo Dragon, cop. 2012, ss. 250, [6].

Krzyściak-Kosińska Renata, Kosiński Marek. Atlas roślin. Wyd. 2. Bielsko-Biała: Wydawnictwo Dragon, 2012, ss. 95.

Lewkowicz-Mosiej Teresa. Rośliny lecznicze. Leksykon. Warszawa: Świat Książki, 2012, ss. 431, k. tabl. [16] [zawiera indeksy nazw polskich, łacińskich, angielskich, francuskich, niemieckich, rosyjskich].

Mój zielnik. Kwiaty i zioła. Opisy roślin, barwne ilustracje, miejsca do wklejania. Red. Beata Horosiewicz. Poznań: Olimp Media, cop. 2012, ss. 79. 
Przybyłowiczowie Anna i Łukasz. Rośliny: rośliny łąkowe. Cz. 1. Red. prowadzący Jakub Czajkowski, Paweł Zalewski. Seria Encyklopedia Przyrody: skarby polskiej natury, t. 13. Warszawa: De Agostini Polska, cop. 2012, ss. 48.

Przybyłowiczowie Anna i Łukasz. Rośliny: lasy - krzewy i rośliny zielne. Cz. 1. Red. prowadzący Jakub Czajkowski, Paweł Zalewski. Seria Encyklopedia Przyrody: skarby polskiej natury, t. 16. Warszawa: De Agostini Polska, cop. 2012, ss. 48.

Przybyłowiczowie Anna i Łukasz. Rośliny: rośliny wodne i bagienne. Cz. 1. Red. prowadzący Jakub Czajkowski, Paweł Zalewski. Seria Encyklopedia Przyrody: skarby polskiej natury, t. 19. Warszawa: De Agostini Polska, cop. 2012, ss. 48.

Przybyłowicz Łukasz. Rośliny: rośliny parkowe i wprowadzone. Red. prowadzący Jakub Czajkowski, Paweł Zalewski. Seria Encyklopedia Przyrody: skarby polskiej natury, t. 22. Warszawa: De Agostini Polska, cop. 2012, ss. 48.

Przybyłowicz Łukasz. Rośliny: lasy - krzewy i rośliny zielne. Cz. 2. Red. prowadzący Jakub Czajkowski, Paweł Zalewski. Seria Encyklopedia Przyrody: skarby polskiej natury, t. 25. Warszawa: De Agostini Polska, cop. 2012, ss. 48.

Przybyłowiczowie Anna i Łukasz. Rośliny: rośliny łąkowe. Cz. 2. Red. prowadzący Bartosz Kunowski, Paweł Zalewski. Seria Encyklopedia Przyrody: skarby polskiej natury, t. 29. Warszawa: De Agostini Polska, cop. 2012, ss. 48.

Przybyłowicz Łukasz. Rośliny: rośliny wodne i bagienne. Cz. 2. Red. prowadzący Bartosz Kunowski, Paweł Zalewski. Seria Encyklopedia Przyrody: skarby polskiej natury, t. 32. Warszawa: De Agostini Polska, cop. 2012, ss. 48.

Przybyłowicz Łukasz. Rośliny: rośliny lecznicze. Red. prowadzący Bartosz Kunowski, Paweł Zalewski. Seria Encyklopedia Przyrody: skarby polskiej natury, t. 35. Warszawa: De Agostini Polska, cop. 2012, ss. 48.

Przybyłowicz Łukasz. Rośliny: lasy - krzewy i rośliny zielone. Cz. 3. Red. prowadzący Bartosz Kunowski, Paweł Zalewski. Seria Encyklopedia Przyrody: skarby polskiej natury, t. 38. Warszawa: De Agostini Polska, cop. 2012, ss. 48.

Rapiejko Piotr. Alergeny pyłku roślin. Wyd. 3. Warszawa: Medical Education, 2012, ss. 100 [CD pt.: Atlas fotografii roślin alergogennych. Zawiera 1515 zdjęć roślin, których ziarna pyłku mają właściwości uczulające, fotografie przedstawiaja kwiatostany i liście $w$ różnych fazach rozwoju oraz obrazy mikroskopowe ziaren pyłku].

Słownik roślin medycznych. Tł. Anna Matusik. Seria Biblioteczka Domowa. Zielarstwo, t. 7. Ożarów Mazowiecki: Wydawnictwo Olesiejuk, cop. 2012, ss. 57.

Styczyński Marek. Zielnik podróżny. Rośliny w tradycji Karpat i Bałkanów. Przewodnik alternatywny. Wprowadzenie do etnobotaniki. Krosno: Wydawnictwo Ruthenus, cop. 2012, ss. 319, s. tabl. [8].

Urbisz Andrzej. Atlas rozmieszczenia roślin naczyniowych na Wyżynie Krakowsko-Częstochowskiej = Distribution atlas of vascular plants in the Kraków-Częstochowa uplands. Katowice: Centrum Dziedzictwa Przyrody Górnego Śląska, 2012, ss. 397.

Waniakowa Jadwiga. Polskie gwarowe nazwy dziko rosnacych roślin zielnych na tle słowiańskim. Zagadnienia ogólne. Kraków: Wydawnictwo Uniwersytetu Jagiellońskiego, 2012, ss. 282, [1] [zawiera indeksy nazw (s. 279-282): polskie nazwy naukowe, s. 251-253; polskie i kaszubskie nazwy potoczne, gwarowe $i$ historyczne, s. 253-262; łacińskie nazwy naukowe, s. 262-264; łacińskie nazwy historyczne, s. 264266; greckie nazwy historyczne, s. 266-266; nazwy słowiańskie: nazwy prasłowiań- 
skie (s. 266-266), nazwy staro-cerkiewno-słowiańskie (s. 266-266), nazwy czeskie (s. 266-269), nazwy słowackie (s. 269-270), nazwy łużyckie (s. 272-272), nazwy białoruskie (s. 271-272), nazwy ukrainskie (s. 272-274), nazwy rosyjskie (s. 274-275), nazwy z Polesia (s. 275-275), nazwy słoweńskie (s. 275-276), nazwy serbskie i chorwackie (s. 276-278), nazwy bułgarskie i macedonskie (278-279), s. 266-279; nazwy niesłowiańskie: nazwy niemieckie (s. 279-281), nazwy niderlandzkie (s. 281-281), nazwy angielskie (s. 281-281), nazwy włoskie (s. 281-282)].

Witkowska-Żuk Leokadia. Atlas roślinności lasów. Seria Flora Polski. Warszawa: Multico Oficyna Wydawnicza, cop. 2012, ss. 592.

Zielnik czarodziejski to jest Zbiór przesądów o roślinach, przez Józefa Rostafińskiego, Warszawa: Grafika Iwona Knechta, 2012, ss. 200, [2].

Zioła i rośliny lecznicze: kieszonkowy atlas. Tł. Cezary Franciszek Murawski. Red. Bożena Zasieczna. Warszawa: Muza SA, 2012, ss. 192, k. tabl. [1].

\section{3}

Chamovitz Daniel. Zmysłowe życie roślin: podręczny atlas zmysłów. Przeł. Dariusz Wójtowicz. Warszawa: Wydawnictwo WAB, 2013, ss. 183, [9] [na okł.: Co wiedza rośliny?].

Ewolucja roślin i zwierząt. Tekst Jaromir Jaskuła. Red. prowadzący Paweł Zalewski. Seria Encyklopedia Przyrody: skarby polskiej natury, t. 59. Warszawa: De Agostini Polska, cop. 2013, ss. 48.

Hołubowicz-Kliza Grażyna, Mrówczyński Marek. Atlas szkodników i owadów pożytecznych w integrowanej ochronie roślin. Puławy: Instytut Uprawy Nawożenia i Gleboznawstwa - Państwowy Instytut Badawczy - Poznań: Instytut Ochrony Roślin - Państwowy Instytut Badawczy, 2013, ss. 248.

Mederska Małgorzata. Atlas roślin leczniczych. Seria Wademekum. Warszawa: Wydawnictwo SBM, cop. 2013, ss. 191 [1] [na s. tyt.: Ponad 230 gatunków].

Myśliwy Monika, Schimrosczyk Reinhard-Richard. Słownik roślin leczniczych polsko-niemiecki = Heilpflanzen Wörterbuch Deutsch-Polnisch. Szczecin: Wydawnictwo Hogben s.c., 2013, ss. 636.

Przybyłowicz Anna i Łukasz. Ilustrowana encyklopedia roślin Polski. Seria Klub Miłośników Książki. Warszawa: Dom Wydawniczy PWN, 2013, ss. 288.

Przybyłowicz Łukasz. Rośliny. Rośliny uprawne. Red. prowadzący Bartosz Kunowski, Paweł Zalewski. Seria Encyklopedia Przyrody: skarby polskiej natury, t. 41. Warszawa: De Agostini Polska, cop. 2013, ss. 48.

Przybyłowicz Łukasz. Rośliny: paprotniki, mszaki i porosty. Red. prowadzący Bartosz Kunowski, Paweł Zalewski. Seria Encyklopedia Przyrody: skarby polskiej natury, t. 44. Warszawa: De Agostini Polska, cop. 2013, ss. 48.

Przybyłowicz Łukasz. Rośliny. Rośliny łąkowe. Cz. 3. Red. prowadzący Paweł Zalewski. Seria Encyklopedia Przyrody: skarby polskiej natury, t. 47. Warszawa: De Agostini Polska, cop. 2013, ss. 48.

Przybyłowicz Łukasz. Rośliny. Anatomia i rozwój. Red. prowadzący Paweł Zalewski. Seria Encyklopedia Przyrody: skarby polskiej natury, t. 58. Warszawa: De Agostini Polska, cop. 2013, ss. 48. 
Przyroda Bielan warszawskich. Red. nauk. Maciej Luniak. Wyd. 2. Muzeum i Instytut Zoologii PAN. Warszawa 2013, ss. 312 [Stowniczek nazw gatunków roślin i zwierząt w języlu polskim i łacińskim].

Sipowicz Kamil. Encyklopedia polskiej psychodelii: [od Mickiewicza do Masłowskiej, od Witkacego do street-artu]. Warszawa: Wydawnictwo Krytyki Politycznej, 2013, ss. $445,[3]$.

[Syreński Szymon]. Zielnik Herbarzem z ięzyka Łacinskiego zowią. To iest Opisanie własne imion, ksztattu, przyrodzenia, skutkow, y mocy Zioł wszelakich Drzew, Krzewin y korzenia ich, Kwiatu, Owocow, Sokow Miasg, Zywic y korzenia do potraw zaprawowania Takze Trunkow, Syropow, Wodek Lekiwarzow, Konfectow [...] Polskiem iezykiem zebrany y na osmiero ksiag rozłozony [...]. Pilnie zebrane a porządnie zpisane przez D. Simona Syrennivsa. Warszawa: Grafika, 2013, ss. [22], 1540, [20] [tyt. okł.: Zielnik D. Symona Syreniusa Herbarzem z iezyka Lacinskiego zowia To iest Opisanie własne imion, kształtu, przyrodzenia, skutkow, y mocy Zioł wszela].

Szcześniak Krystyna. Świat roślin światem ludzi na pograniczu wschodniej i zachodniej Słowiańszczyzny. Wyd. 2 popr. Gdańsk: Wydawnictwo Uniwersytetu Gdańskiego, 2013, ss. 410, + 1 dysk opt. CD-ROM [zawiera Słownik [magicznych zastosowań roślin, których nazwy zostały zapisane w słowniczku Zośki Wieras i w fitonimicznych materiałach Elizy Orzeszkowej], s. 120-335 (z ekwiwalentami białoruskimi, rosyjskimi i łacińskimi); Indeks nazw roślin: Nazwy łacińskie (355-363); Nazwy pisane cyrylica (s. 363-380); Nazwy zapisane tacinka (s. 380-410)].

\section{4}

Atlas przyrody. Red. Justyna Brodłowicz, Małgorzata Gasińska, Izabela Jędraszek. Wierzchy Parzeńskie: P.H.W. Fenix, [2014], ss. 96.

Bieniek Adam. Podręczny zielnikśredniowiecznego muzułmanina. Księga dziwów stworzenia i cudów istnienia Al-Qazwiniego (XIII wiek) oraz zawarte w niej nazewnictwo i opisy roślin użytkowych. T. 1. Kraków: Księgarnia Akademicka, cop. 2014, ss. 110. Halarewicz Aleksandra. Atlas roślin: 200 gatunków. Seria Wademekum. Warszawa: Wydawnictwo SBM, 2014, ss. 185, [7] [na okł.: 200 polskich gatunków].

Hołubowicz-Kliza Grażyna, Mrówczyński Marek. Atlas szkodników i owadów pożytecznych $w$ integrowanej ochronie roślin. Puławy - Poznań: Wydawnictwo IUNG-PIB, 2014, ss. 248.

Iwaniuk Arkadiusz. Atlas ziół krajowych. Warszawa: Bellona, cop. 2014, ss. 142, [2].

Kurowski Lucjan. Drzewa i krzewy iglaste. Seria Ekspert w Ogrodzie. Warszawa: Multico Oficyna Wydawnicza, cop. 2014, ss. 328 [indeks].

Macieszyna Maria. Zielnik Płocka i okolicy. Rękopis z I poł. XX w. [Dokument elektroniczny]. Towarzystwo Naukowe Płockie. Biblioteka im. Zielińskich. Raszyn: Mikrofilm-Service, [ca 2014], 1 dysk optyczny (CD-ROM).

Mazik Michał. Rośliny ozdobne. Encyklopedia. Seria Twój Expert w Domu. Bielsko-Biała: Wydawnictwo Dragon, cop. 2014, ss. 189, [3].

Mróz Iwona, Wójcik Michał. Ilustrowany atlas roślin. Kalisz: Wydawnictwo i Dystrybucja Książek Martel, 2014, ss. 151. 
Pelcowa Halina. Słownik gwar Lubelszczyzny. T. 2: Rolnictwo: transport wiejski, rośliny okopowe i paszowe, gleby i rodzaje pól, uprawa lnu i konopi, zbiór siana. Lublin: Wydawnictwo Uniwersytetu Marii Curie-Skłodowskiej, 2014, ss. 459.

Pierścińska Agnieszka. Rośliny naczyniowe wschodniej części Niecki Połanieckiej (Wyżyna Małopolska) i przyległej części Niziny Nadwiślańskiej (Kotlina Sandomierska) = Vascular plants of the eastern part of the Połaniec Basin (Małopolska Upland) and adjacent part of the Nadwiślańska Lowland (Sandomierz Basin). Seria Prace Botaniczne, Instytut Botaniki Uniwersytetu Jagiellońskiego 45. Kraków: nakładem Instytutu Botaniki Uniwersytetu Jagiellońskiego, 2014, ss. 354.

Pliszko Artur. Flora roślin naczyniowych Pojezierza Zachodniosuwalskiego = The vascular plant flora of the Zachodniosuwalskie Lakeland. Seria Prace Botaniczne, Instytut Botaniki Uniwersytetu Jagiellońskiego 48. Kraków: nakładem Instytutu Botaniki Uniwersytetu Jagiellońskiego, 2014, ss. 349.

Senderski Mateusz Emanuel. Zioła w leczeniu dolegliwości i chorób układu moczowo-płciowego, seri Mądrość Natury, 7. Podkowa Leśna: Wydawca Mateusz E. Senderski, cop. 2014, ss. 446 [zawiera indeksy].

Urbisz Alina, Urbisz Andrzej. Atlas rozmieszczenia roślin naczyniowych w Rybniku. Katowice: Centrum Dziedzictwa Przyrodu Górnego Śląska, 2014, ss. 119 [tekst równoległy polski i angielski].

Urbisz Andrzej, Urbisz Alina. Rośliny naczyniowe Rybnika = Vascular plants of Rybnik. Katowice: Centrum Dziedzictwa Przyrody Górnego Śląska, 2014, s. 249.

Wilson Andrew. Encyklopedia małego ogrodu. Specjalistyczne fot. Steven Wooster. Royal Horticultural Society. Tłum. TERKA - Marek Halczuk. Poznań: Publicat Wydawnictwo, cop. 2014, ss. 224 [na okł.: Jak najlepiej wykorzystać niewielka przestrzeń pod gołym niebem].

Zielnik dla każdego: czyli opis ziół wykorzystywanych w leczeniu domowym wraz z praktycznym zastosowaniem: (napary, wywary i wyciagi zdrowotne). Zebrali i oprac. Jan Rogala oraz Robert Maciej. Ożarów Mazowiecki: Wydawnictwo Olesiejuk, cop. 2014, ss. 175, [1] [zawiera Spis chorób i wykaz ziół leczniczych].

\section{5}

Bogdański Mirosław. Bardzo rzadkie gatunki roślin synantropijnych zebrane $w$ latach 1987-2014 w Polsce. Zielnik. Krzeszowice: Wydawnictwo „Kubajak”, 2015, ss. 74.

Bogdański Mirosław. Rzadkie gatunki roślin we florze synantropijnej terenów kolejowych linii Kraków-Katowice-Kielce zebrane w latach 1985-2014 w Polsce. Zielnik. Krzeszowice: Wydawnictwo „Kubajak”, 2015, ss. 30.

Fiedoruk Łukasz, Mazik Michał, Pastwa Marcin. Zioła: encyklopedia. Seria Twój Expert w Domu. Bielsko-Biała: Wydawnictwo Dragon, 2015, ss. 191, [1].

Halarewicz Aleksandra. Atlas ziół: 120 jadalnych gatunków. Seria Wademekum. Warszawa: Wydawnictwo SBM, 2015, ss. 191, [1] [na okł.: Kulinarne wykorzystanie roślin dziko rosnących].

Korbas Marek, Czubiński Tomasz, Horoszkiewicz-Janka Joanna, Jajor Ewa, Danielewicz Jakub. Atlas chorób roślin rolniczych dla praktyków. Poznań: Polskie Wydawnictwo Rolnicze, 2015, ss. 368. 
López María Tránsito, Máñez Carlota. Zioła. Naturalne sposoby na różne dolegliwości, Przekład Karolina Sikora-Zachariasz. Seria Leksykon Zdrowia, 3. Warszawa: Ringier Axel Springer Polska - [Kielce]: Wydawnictwo Jedność, cop. 2015, ss. 95, [1].

Mederska Małgorzata, Mederski Paweł. Atlas dzikich kwiatów: kulinarne i lecznicze wykorzystanie kwiatów dziko rosnacych. Seria Wademekum. Warszawa: Wydawnictwo SBM, cop. 2015, ss. 191, [1].

Pawłowska Jolanta, Pawłowski Jacek. Atlas roślin Doliny Baryczy: charakterystyczne gatunki roślin. Il. Jakub Józefczuk, Milicz: Stowarzyszenie „Partnerstwo dla Doliny Baryczy”, 2015, ss. 124 [u góry okł. nazwa programu: Edukacja dla Doliny Baryczy].

Przybyłowiczowie Anna i Łukasz. Ilustrowana encyklopedia roślin Polski: atlas. Wyd. 1, dodruk. Warszawa: Dom Wydawniczy PWN, 2015, ss. 288.

Zubel Robert, Danylkiv Ihor, Rabyk Iryna, Lobaczevs'ka Oksana, Soroka Miroslava. Bryophytes of the Roztocze region (Poland and Ukraine): a checklist of liverworts and mosses. Lublin: Towarzystwo Wydawnictw Naukowych Libropolis, 2015, ss. 146.

\section{6}

Bogdański Mirosław. Rzadkie gatunki chwastów polnych zebrane w latach 1981-2015 w Polsce. Zielnik. Krzeszowice: Wydawnictwo „Kubajak”, 2015, ss. 122.

Brodacki Michał. Przyroda ojczysta. Encyklopedia dla całej rodziny. Warszawa: MULTICO Oficyna Wydawnicza, cop. 2016, ss. 224.

Gawryś Wiesław. Słownik roślin zielnych: łacińsko-polski. Kraków: Officina Botanica, 2008, ss. 199.

Hołubowicz-Kliza Grażyna. Rolniczy atlas chorób. Puławy: Wydawnictwo IUNG-PIB, 2016, ss. 419.

Ilustrowana encyklopedia zwierząt i roślin Polski. Oprac. Jerzy Abramowicz et al. Warszawa: Dom Wydawniczy PWN - Bełchatów: P. H. W. Fenix, 2016, ss. 608.

Iwaniuk Arkadiusz. Atlas ziół krajowych. Warszawa: Bellona, cop. 2016, ss. 142, [1].

Korbas Marek, Jajor Ewa, Horoszkiewicz-Janka Joanna, Danielewicz Jakub. Atlas chorób roślin rolniczych. Warszawa: Hortpress, 2016, ss. 212.

Kujawska Monika, Łuczaj Łukasz, Sosnowska Joanna, Klepacki Piotr. Rośliny w wierzeniach i zwyczajach ludowych - Stownik Adama Fischera. Seria Prace i Materiały Etnograficzne $=$ Travaux et Materiaux Ethnographiques, Polskie Towarzystwo Ludoznawcze, t. 37. Wrocław: Polskie Towarzystwo Ludowe, 2016, ss. 518, [1].

Leksykon terminologii europejskiej i międzynarodowej w kontroli sanitarnej, fitosanitarnej i farmaceutycznej. Red. Marcin Janik. Katowice: Uniwersytet Śląski - Białystok: Partner Poligrafia, Andrzej Kardasz, 2016, ss. 148, [2].

Mederska Małgorzata. Atlas roślin doniczkowych: 200 gatunków ozdobnych. Seria Wademekum. Warszawa: Wydawnictwo SBM, cop. 2016, ss. 191, [1].

Mirek Zbigniew. Rośliny naczyniowe Rowu Podtatrzańskiego: flora i atlas rozmieszczenia = Vascular plants of the Sub-Tatra Furrow: flora and distribution atlas. Kraków: Instytut Botaniki im. W. Szafera Polskiej Akademii Nauk, 2016, ss. 314.

Motta Giuseppe Bertelli. Lecznicze rośliny Biblii. Tajemnice zdrowotne Pisma Świętego. Tłumaczenie Agnieszka Zielińska, konsultacja i uzupełnienie wydania polskiego Anita Magowska. Kraków: Wydawnictwo Esprit, 2016, ss. 292, [4] [zawiera słownik]. 
Polska czerwona lista paprotników $i$ roślin kwiatowych $=$ Polish red list of pteridophytes and flowering plants. Red. Róża Kaźmierczakowa. Oprac. Róża Kaźmierczakowa, Joanna Bloch-Orłowska, Zbigniew Celka, Anna Cwener, Zygmunt Dajok, Dorota Michalska- Hejduk, Paweł Pawlikowski, Ewa Szczęśniak, Krzysztof Ziarnek. Instytut Ochrony Przyrody. Polska Akademia Nauk. Kraków: Instytut Ochrony Przyrody. Polska Akademia Nauk, 2016, ss. 44.

Rejewski Marian. Nazwy roślin. Toruń: Wydawnictwo Naukowe Uniwersytetu Mikołaja Kopernika, 2016, ss. 323, [2].

Rośliny lecznicze. Tekst Dorota Gnatowska. Seria Kolekcje Muzeum Rolnictwa im. ks. Krzysztofa Kluka w Ciechanowcu. Ciechanowiec: Muzeum Rolnictwa im. ks. Krzysztofa Kluka - Białystok: Urząd Marszałkowski Województwa Podlaskiego. Departament Kultury i Dziedzictwa Narodowego, 2016, ss. [4], 324.

Rośliny ozdobne: ogród z pasją. Tekst Krzysztof Ulanowski. Seria Natura - Books. Żychlin: Books, 2016, ss. 76, [4].

Rysiak Anna. Atlas of distribution of vascular plants in Lublin = Atlas rozmieszczenia roślin naczyniowych w Lublinie. Lublin: Kartpol, 2016, ss. 214.

Senderski Mateusz Emanuel. Zioła dla układu oddechowego i oczu. Seria Mądrość Natury, 8. Podkowa Leśna: Wydawca Mateusz E. Senderski, cop. 2016, ss. 256, XV [zawiera indeksy].

Styczyński Marek. Zielnik podróżny. Rośliny w tradycji Karpat i Bałkanów. Przewodnik alternatywny. Wprowadzenie do etnobotaniki. Krosno: Wydawnictwo Ruthenus, cop. 2016, ss. 319, s. tabl. [8].

Zielnik czarodziejski to jest Zbiór przesądów o roślinach. Przez Józefa Rostafińskiego. Katowice: P.H.U. Zeta Tadeusz Zawada, 2016, ss. [2], 191, [1].

\section{7}

Atlas roślin Polski. Aut. tekstu Renata Krzyściak-Kosińska, Marek Kosiński. Seria Unica, Bielsko-Biała: Wydawnictwo Dragon, 2017, ss. 30, [2] [na okł. podt.: Kompendium wiedzy dla dzieci wrażliwych na piękno przyrody].

Fijołek Monika. Atlas dzikich roślin jadalnych: 150 polskich gatunków. Seria Wademekum. Warszawa: Wydawnictwo SBM, 2017, ss. 191, [1].

Mazik Michał. Rośliny wodne: uprawa, pielegnacja. Seria Poradnik Ogrodnika - Natura. Bielsko-Biała: Wydawnictwo Dragon, 2017, ss. 47, [1].

Mederska Małgorzata. Ilustrowany leksykon roślin leczniczych: ponad 230 gatunków ziól, owoców i ich zastosowanie, Chorzów: Grupa Arkadia, 2017, s. 191, [1]. 